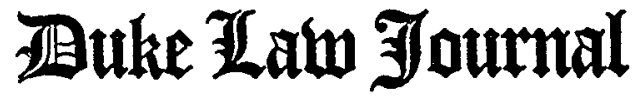

\begin{tabular}{lll}
\hline VOLUME 1976 & DECEMBER & NUMBER 5 \\
\hline
\end{tabular}

\section{ACT OF STATE AT BAY: A PLEA ON BEHALF OF THE ELUSIVE DOCTRINE}

\author{
Alan C. SWan*
}

INTRODUCTION

I. The Debate and Its Implications

A. The Content of the Debate

B. The Larger Implications

II. JUSTICE FOR AMERICAN Claimants

A. The Citibank Decision

B. The Dunhill Decision

III. LaW, Policy and the Polittcal Question

A. Citibank-Of Cuban Confiscations and American Deprivations 835

B. Citibank and the Uses of International Law $\quad 836$

1. Sardino as Contrary to International Law _-_

2. Sardino as Conforming to International Law ___

C. Citibank and the Political Question Doctrine - - -

\begin{tabular}{ll} 
1. Introduction \\
2. Of Analytic Modes _- \\
\hline
\end{tabular}

3. Of Subject Matter $-\square+\square-\square=\square$

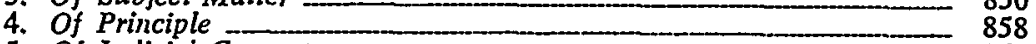

5. Of Judicial Competence

6. Summary $\longrightarrow$ -

D. The Dunhill Decision ——_ _ — - _ -

IV. SUMMARY AND FORWARD LOOK ____ 870

A. The Further Inquiry

B. A Catalogue of Wider Uses -1

$\begin{array}{ll}\text { 1. Of Scope } & 876 \\ \text { 2. Of Encroachment on the Political Realm } & 878\end{array}$

3. Of Encroachments on the Settlement of Disputes $\square-\square$

4. Of What Remains

V. THE WIDER USES OF THE DOCTRINE ___ 883

A. Constitutional Practice -

1. A Normative Dimension

2. Of Magnitude and Comprehensiveness -

3. Of "Evils To Be Eradicated" - 891

B. The Consequences of Judging _ _ _ _ _ 898

1. Where Standards Diverge -1

C. The Territorial Limitation

CONCLUSION —___ 990 


\section{INTRODUCTION}

In 1964 the Supreme Court handed down its much noted decision in Banco Nacional de Cuba v. Sabbatino. ${ }^{1}$ Writing over a single dissent, ${ }^{2}$ the late Mr. Justice Harlan held that under the "act of state" doctrine the courts of the nation, state and federal alike, were not to judge whether the expropriatory decrees of a recognized foreign government were valid under customary international law in cases where the property in issue was located within that government's territory. ${ }^{8}$ Less than a decade later, the Justices concluded in First National City Bank v. Banco Nacional de Cuba ${ }^{4}$ that the courts could judge the validity of the very decree of the Cuban government ${ }^{5}$ which Justice Harlan had declined to review.

Contrary to the position taken by the Executive in Sabbatino, ${ }^{8}$ the Department of State's Legal Adviser had indicated to the Court in Citibank that the nation's foreign policy interests did not require application of the doctrine under the special circuinstances of that case. ${ }^{7}$ This eleventh hour intervention was an open invitation for the Court to reshape the doctrine-to make it a rule concerned only with avoiding embarrassments to foreign policy and to reject the more expansive catalogue of considerations upon which, in the view taken here, Justice Harlan had relied in footing the doctrine upon the "constitutional' underpinnings" of the separation of powers principle. ${ }^{8}$

Perhaps the results were to be expected. Mirroring the decadelong attack on Sabbatino, four Justices appeared to accept the Legal Adviser's invitation. Justice Rehnquist, writing the plurality opinion, plainly did so. He denied that the doctrine rested upon any constitutional footing whatsoever and offered "deference" to the Executive and

* Associate Professor of Law, University of Miami; B.A. 1954, Albion College; J.D. 1957, University of Chicago.

1. 376 U.S. 398 (1964).

2. Id. at 439 (White, J., dissenting).

3. Id. at 428.

4. 406 U.S. 759 (1972).

5. Law 851 of July 6, 1960, Official Gazette of Cuba, reproduced in Sabbatino, 376 U.S. at 403 n.7.

6. Brief for the United States as Amicus Curiae at 30, 32, 33, Banco Nacional de Cuba v. Sabbatino, 376 U.S. 398 (1964).

7. Letter from John R. Stevenson, Legal Adviser, Dep't of State to E. Robert Seaver, Clerk of the United States Supreme Court, Nov. 17, 1970, reproduced in Banco Nacional de Cuba v. First Nat'l City Bank, 442 F.2d 530, 536 et seq. (2d Cir. 1971), rev'd, 406 U.S. 759 (1972).

8. Sabbatino, 376 U.S. at 423.

9. Justice Rehnquist's opinion was joined by the Chief Justice and Justice White. 
"international comity" as alternative predicates. ${ }^{10}$ Justice Powell was more subtle. While professing agreennent with the principles of Sabbatino, he declimed to embrace the results in that case, offering a rationale for doimg so that would seem to pose no less a challenge to that decision than does Justice Rehnquist's effort. ${ }^{11}$

Provoked by this retreat and determined to preserve the broader considerations enumerated in Sabbatino, Justice Brennan, writing for the four dissenters, appeared to push a step beyond Justice Harlan's position in the earlier case. ${ }^{12}$ Where the latter had expressly declined to view act of state as compelled by the Constitution, treating it only as a rule of "federal common law,"13 Justice Brennan insisted that it could, in appropriate circumstances, signal the presence of a nonjusticiable "political question" which the Executive could not by "simple stipulation" convert into a "cognizable claim."14 Citibank, in his view, was just such a case.

This is where the Court stood, divided-perhaps evenly divided ${ }^{15}$ -over the merits of Sabbatino, when last tern it assigned the case of

10. Justice Rehnquist found the roots of the act of state doctrine "not in the Constitution, but in the notion of comity between independent sovereigns." Id. at 765 . In his view, this foundation was

buttressed by judicial deference to the exclusive power of the Executive over conduct of relations with other sovereign powers and the power of the Senate to advise and consent on the making of treaties.

Later, however, this "buttressing" consideration appears to have become the whole of the rule:

The act of state doctrine is grounded on judicial concern that application of customary principles of law to judge the acts of a foreign sovereign might frustrate the conduct of foreign relations by the political branches of the government. We conclude that where the Executive Branch, charged as it is with prinary responsibility for the conduct of foreign affairs, expressly represents to the Court that application of the act of state doctrine would not advance the interests of American foreign policy, that doctrine should not be applied by the courts. In so doing, we of course adopt and approve the socalled Bernstein exception to the act of state doctrine. We believe this to be no more than an application of the classical common-law maxim that "[t]he reason of the law ceasing, the law itself also ceases." Id. at 767-68, citing BLACK's LAw DictionarY 288 (4th ed. 1951).

11. See id. at 773-76 (Powell, J., concurring); see notes 31-32 infra and accompanying text.

12. Justice Brennan wrote for himself and for Justices Stewart, Marshall and Blackmun. 406 U.S. at 776 (Brennan, J., dissenting).

13. 376 U.S. at $423,425-27$.

14. 406 U.S. at 787-89.

15. The final and decisive vote in favor of an adjudication in Citibank was supplied by Justice Douglas, who took the position that the case was controlled by National City Bank v. Republic of China, 348 U.S. 356 (1955). In both Republic of China and Citibank, Justice Douglas saw a foreign government requesting the assistance of American courts in vindicating its legal rights. Therefore, in the Justice's view, fair dealing required that any counterclaim or set-off be subject to an adjudication up to the amount of the claim asserted by Cuba. A dispute over any amounts in excess of Cuba's claim would not be justiciable under Sabbatino. 406 U.S. at 770-73. 
Alfred Dunhill of London, Inc. v. Republic of Cuba for reargument and asked the parties to brief and discuss the question of whether Sabbatino should be reconsidered. ${ }^{18}$ The Dunhill decision has now been issued, ${ }^{17}$ but without the projected reconsideration of Sabbatino. Instead, the Court appears to remain deadlocked over the merits of that decision and the fundannental definition of the act of state doctrine's theoretical underpinnings. With Mr. Justice Stevens concurring in the result on technical grounds, ${ }^{18}$ Dunhill supplies an appropriate occasion for re-examining the Court's contmuing struggle with that venerable but elusive doctrine. This is especially true since the Legal Adviser indicated to the Court that his department anticipated no "embarrassment to the conduct of foreign policy" if Sabbatino were overruled, ${ }^{10}$ and the Solicitor General recoininended a sweeping "commercial obligations" exception to the doctrine. ${ }^{20}$ The decision itself, moreover, offers another, although distinctive, illustration of the basic theoretical error undergirding the challenge to that decision.

The act of state doctrine, it must be emplasized, is concerned with the consequences of judicial action. Theories of the doctrine are shorthand statements of a number of decisional elements. They serve to identify those public and private interests that are to be protected from judicial action, and are implicitly undergirded by particular assumptions regarding the effects of such action. They also identify the broader social outcomes, judicial obligations and values which largely determine when the anticipated consequences of an adjudication are unacceptable. And implicit in most theories of the doctrine are particular views regarding the nature of law and of the international legal order, views which ean-and often do-critically influence the content and weight assigned the other decisional elements.

16. Menendez v. Saks \& Co., 485 F.2d 1355 (2d Cir. 1973), cert. granted sub nom. Alfred Dunhill of London, Inc. v. Republic of Cuba, 416 U.S. 981 (1974), assigned for reargument, 422 U.S. 1005 (1975) (Court Order: "In addition to other questions presented by this case, counsel are requested to brief and discuss during oral argunent: Should this Court's holding in Banco Nacional de Cuba v. Sabbatino, 376 U.S. 398 (1964), be reconsidered?").

17. 96 S. Ct. 1854 (1976).

18. With Justice White, writing for the Citibank plurality, and Justices Powell and Stevens each concurring separately, the Court determined that the "act of state" doctrine should not be applied to Dunhill's claim. $96 \mathrm{~S}$. Ct. at 1856-67. Justice Marshall, writing for the Citibank dissenters, would have applied the doctrine on the authority of Sabbatino, see id. at 1871-82. See notes 43-44 infra and accompanying text.

19. Letter from Monroe Leigh, Legal Adviser, Dep't of State, to the Solicitor General, Nov. 26, 1975, reproduced in Dunhill, 96 S. Ct. at 1867, app. 1.

20. Brief for the United States as Anicus Curiae at 27, 28, Alfred Dunhill of London, Inc. v. Republic of Cuba, 96 S. Ct. 1854 (1976). 
This is precisely what is found in the Court's debate. Led by their values, their desire for certain social outcomes, their general view of the legal order, the Justices challenging Sabbatino have sought to narrow the judicial perspective, expressed in terms of the catalogue of relevant consequences, to a degree that cannot be reconciled with Justice Harlan's opinion. Their tolerance for such consequences as are admitted must be seen as a repudiation of many of the basic sensitivities underlying Sabbatino.

When the challengers' alternative prescriptions are tested against a number of benchmarks, they cannot, it is suggested, stand. Their preference as among the competing interests at stake in both Citibank and Dunhill, their disregard for the integrity of the American judiciary, their refusal to recognize the iniport of their theories for the wider interests of this nation and for the "rule of law" among all nations, combime to demonstrate the wisdom of Justice Harlan's more comprehensive paradign. At bottom, the challengers have espoused a course of action that can, as Citibank illustrates, serve only to undermine the foundations of judicial legitimacy in the American scheme of government. They would compel the courts to choose between decision according to reasoned principles, on the one hand, and protecting some of the most dehicate and momentous policies that any nation may occasionally be compelled to pursue, on the other. They have proffered a course that can scarcely enhance the cause of justice and good order in the international community.

From the analysis upon which these conclusions rest, several broader formulations follow. First, act of state is a doctrine concerned with the limits of legitimate judicial action, and as such rests upon a constitutional predicate that can certainly encompass a political question but need not do so. If the political question doctrine has typically been applied to forestall judicial imquiry imto acts of federal and state governments, act of state may, in the appropriate case, be the precise constitutional analog forestalling inquiry imto the acts of foreign governments. But it has a wider ambit. While drawing upon the same set of basic constitutional ideas as the political question doctrine, act of state is nevertheless unique in its concern with the role domestic courts should play in the search for a more workable international order. It is, $\mathrm{m}$ short, a rule with "constitutional underpinmings" which may converge with the political question doctrine in a way that is instructive but not definitive.

Second, the fact that a particular legal cliallenge to an act of a foreign state rises to the status of a political question is not, in most cases, an operationally significant conclusion. It is subinitted that, con- 
trary to Justice Brennan's implicit suggestion (with which Justices Marshall and Powell appear to concur), the role that Congress and the Executive are to play in the management of the doctrine cannot be inade to turn exclusively upon the distinction between a constitutional ordinance (i.e., political question) and a mere rule of judicial legislation.

Finally, precisely as Sabbatino and Citibank serve, by their distinctive factual context, to show how securely Justice Harlan's holding was rooted in a constitutional command, they warn that the same mandate may become less compelling on the periphery of the doctrine's applicability. Indeed, a substantial gap inust be bridged before it may be said that the analysis of those two cases, and the equally distinctive pre-Sabbatino decisions of the Court, supply a sufficient basis for Justice Harlan's sweeping interdiction. Because it also arose out of a quarrel with Cuba, Dunhill does not close the gap. Nevertheless, when the essential lessons of Citibank and Dunhill are extended to the wider possibilities for the doctrine, the wisdoin which undergirds the Sabbatino decision is apparent. Even if, in these peripheral areas, it should be concluded that Justice Harlan's broad interdiction is not the product of a constitutional edict, its underpinnings are nevertheless to be found in the Constitution, and in that larger search for order and justice which is the ultimate object of the rule of law among nations.

In developing these arguments, this Article begins in Part I with a review of the content and theoretical implications of the Court's debate. Part II examines the coinpatibility of the Cuban decisions, particularly Citibank and Dunhill, with certam basic notions of justice in American society. Part III considers the manner in which these decisions raise the larger issue of judicial legitimacy. It analyzes the unfortunate choice which those Justices who challenge Sabbatino would impose upon the courts, and places that choice in the historical context of the political question doctrine. It also lays the groundwork for a discussion of the conceptual umiqueness of act of state. Part IV offers a "Summary and Forward Look." Its initial object is to indicate how substantially the holding in Sabbatino extended the doctrine beyond the immediate needs of that case or the leading decisions upon which it was predicated. To test the inerits of that extension, a rough catalogue of foreign state acts is offered along with an assessment as to when, in dealing with such acts, the courts are likely to confront a political question in the classic model described in Part III. Part V takes the concluding step, suggesting that resort to the act of state doctrine in the more peripheral categories of its application is compelled by that 
need to preserve the integrity of the courts which the Cuban cases so pointedly illustrate. Finally, this concern for judicial integrity is reconciled with the territorial limitation which Justice Harlan engrafted upon his holding, suggesting in rough outline those circunstances under which that linitation should be discarded.

\section{The Debate and Its Implicatrons}

\section{A. The Content of the Debate}

In holding that the courts were not to entertain international law challenges to foreign expropriatory decrees, ${ }^{21}$ Justice Harlan devoted inuch of his opinion to what might be called the direct embarrassinents to foreign policy which could flow froin a contrary holding-that, generally, judicial pronouncements upon so sensitive a subject could only strain good relations with foreign governments and render efforts at a negotiated settlement nore difficult. To read the Justice, however, as concerned solely with these direct effects is to ignore mucl of what he had to say, in particular his concern for the subtler effects upon foreign policy and the broader national interest, his fears for the integrity of the courts, and his sense of what justice for private Americans and good order in the international community might require.

Responding to the thought that the American courts could be used to deter foreign governments from confiscating American property, Justice Harlan tendered a very precise calculus. The political departinents, Congress and the Executive, possess the only truly effective

21. Sabbatino involved a dispute between Banco Nacional, an agency of the Cuban government, and an American-owned Cuban firm (C.A.V.), one-time owner of a cargo of sugar sold to an American brokerage firm (Farr, Whitlock \& $\mathrm{Co}$.). The district court held that the sale had occurred after the expropriation of the cargo by Cuba. Banco Nacional de Cuba v. Sabbatino, 193 F. Supp. 375 (S.D.N.Y. 1961). After Farr, Whitlock, with the permission of the Cuban government, sold the sugar and turned the proceeds over to a New York receiver representing C.A.V.'s interests (Sabbatino), Banco Nacional sued to recover the proceeds. Both Farr, Whitlock and C.A.V. (as amicus curiae) resisted the claim on the ground that, because the expropriation violated international law, Cuba had never obtained valid title to the cargo. The district court gave judgment for Farr, Whitlock; the Second Circuit affirmed, but on different grounds. 307 F.2d 845 (2d Cir. 1962). The Supreme Court reversed. 376 U.S. 398 (1964). Between the time of the Supreme Court's decision and the decision of the Second Circuit on remand, Congress enacted the so-called Hickenlooper/Sabbatino amendment, 22 U.S.C. $\$ 2370(e)(2)(1970)$, amending The Foreign Assistance Act of 1961, 22 U.S.C. $\$ 2151$ et seq. (1964). See note 63 infra. Relying on that amendment, the Second Circuit again gave judgment for Farr, Whitlock. Banco Nacional de Cuba v. Farr, 383 F.2d 166 (2d Cir. 1967), cert. denied, 390 U.S. 956 (1968). 
instruments of deterrence. If the threats of boycotts, embargoes, seizure of assets, or termination of foreign aid had succeeded, the need for judicial action would not have arisen. If they had failed, it was fanciful to think that piecemeal judicial actions could succeed. All that the courts could do in such cases was demonstrate their impotence at the expense of both American foreign policy and those injured investors who were depending upon a negotiated settlement. But there is more; the Justice moves on to invoke an even broader concern for national policy and the role of courts in the service of that policy. Had Congress and the Executive not resorted to the more powerful instruments available to them, the courts, even if confident of succeeding in their deterrent purpose, were bound to respect the national interest determination implicit in the political departments' exercise of restraint. ${ }^{22}$

Next, there is the connection between the observed refusal of many nations to accept the traditional international law of expropriation and the Justice's dismissal of the suggestion that American courts could aid in fashioning a more adequate consensus on the point. He found the differences of viewpoint to be rooted in the fundamental disparities of international life-differences of economic and political power and ideological commitment. ${ }^{28}$ He treated almost with scorn the idea that courts in the world's leading exponent of private enterprise and the world's leading exporter of capital might act as tutor to other nations on so sensitive a subject. ${ }^{24}$

Yet he did not abandon all possibilities for an American contribution to the development of a inore adequate international law. $\mathrm{He}$ turued, rather, to the dynamics of consensus building and the role of various institutions in that process. If the question were characterized by fundamental, structurally rooted disparities of national viewpoint, then consensus building in the Justice's view, would be a process involving the advocacy by each nation of norms reflective of its own national interest. For the United States this responsibility lay with the Executive. $^{25}$ Under the basic postulates of American democracy, the courts could serve the cause of justice and good order only through the rea-

22. 376 U.S. at $435-36$.

23. Id. at $429-30$.

24. Id. at 434-35.

25. See id. at 432-33:

When articulating principles of international law in its relation with other states, the Executive Branch speaks not only as an interpreter of generally accepted and traditional rules, as would the courts, but also as an advocate of standards it believes desirable for the community of nations and protective of national concerns. 
soned application of agreed principles and only as they were prepared, through that process, to decide like cases alike. ${ }^{26}$ For the American courts to becoine advocates of a parochial national viewpoint which inight shift with each change in the nation's interests could very well, Justice Harlan implied, thrust those courts into the position of having to choose between the national interest and their own basic integrity, a choice destructive of any contribution they might make to the rule of law annong nations.

A final element in the opinion was the Justice's concern for all the victims of an expropriation, not just those before the court. Confined to pieceneal adjudications, unable to aid all those victims, the courts could only prejudice other efforts toward a broader redress of grievances. ${ }^{27}$ And this concern, he seeined to say, inust be given weight irrespective of the prospects for a general diploinatic settleinent in the particular case or of the State Department's willingness to seek such a settleinent. ${ }^{28}$

In contrast to all of this, Justice Rehnquist in Citibank offered a mixture of counity and deference ${ }^{29}$ that was patently intended to force the judicial perspective into the least spacious confines possible. Under the constraints of deference, a court's concern for the unrepresented victims of an expropriation would cease once Executive concern had ended. The deference theory's connotation of subservience to the Executive eliminated any link between the act of state doctrine and the protection of judicial integrity. In this view, the doctrine is not concerned with conflicts between a court's duty to decide like cases alike

26. Immediately preceding his review of the disparity of national viewpoints on the international law of expropriations, his description of the deeper causes of that disparity and his reflections upon the sensitivity of the question which that disparity evidenced, Justice Harlan explained the relevance of his comments in the following terms:

It should be apparent that the greater the degree of codification or consensus concerning a particular area of international law, the more appropriate it is for the judiciary to render decisions regarding it, since the courts can then focus on the application of an agreed principle to circumstances of fact rather than on the sensitive task of establishing a principle not inconsistent with the national interest or with international justice. Id. at 428.

27. The political departments could engage in diplomacy, bilateral and multilateral, and could resort to economic and political sanctions in efforts to obtain general redress for American victims of the foreign state action. "Judicial determinations of invalidity of title [could], on the other hand, have only an occasional impact." As "[p]iecemeal dispositions .... involving the probability of affront to another state [they] could scriously interfere" with the efforts of the Executive. Id. at 431-32.

28. Notable is Justice Harlan's disregard of Justice White's contrary argument in dissent. See id. at 460-61; compare the position of the United States in its amicus brief, supra note 6 , at $32-33$.

29. See note 10 supra. For the facts in Citibank see notes 63-64 infra and accoinpanying text. 
according to antecedent principle and its duty to serve the national interest.

Gone also was Justice Harlan's fear that the American courts might hinder, rather than aid, the processes of transnational conflict resolution and the development of more adequate norms on subjects where consensus was lacking. Under the deference theory, any observed disparity among national viewpoints would be relevant only if it indicated that an adjudication might embarrass the Executive. Where the Executive had ceased to be concerned with the matter, that disparity would serve only as an indication of a somewhat difficult problem in finding the applicable law. Deference, in sum, was used by Justice Rehnquist to divorce act of state from any larger, organic questions of institutional competence and authority.

In adding comity to deference, Justice Rehnquist nowhere explored the intricate and possibly conflicting ideas that these two concepts tend to import into the decisional process. Suffice it to suggest here that if he was not merely using comity as a meaningless description of a result, his opimion could be read as laying the foundation for a later return to a modified international law exception to act of state. ${ }^{30}$

Placing Justice Powell's Citibank opimion ${ }^{31}$ along this spectrum of views is admittedly a difficult task. Since he professed to concur in the principles of Sabbatino, Justice Powell's announced dissent from the results of that decision may have reflected nothing more than a disagreement with Justice Harlan's assessment of the particular dangers of an adjudication in that case. Plainly, he was not prepared to treat the Legal Adviser's invitation to adjudicate ${ }^{32}$ as controlling, and he acknowledged the possibility of a convergence with the political ques-

30. Consider the following possibility: As an emanation of international comity, act of state would seem to mandate only that respect which the courts of one nation ought to accord the public acts of another in the interests of a just and viable international order. Since deference to the Executive appears to exclude all of those larger institutional concerns outlined in Sabbatino (except the concern for foreign policy), there would seem to remain only the substantive norms of international law for comity to import into the search for a more viable international order. Comity mixed with deference becomes, in short, a code word for the principle that the courts of the United States ought not to respect any foreign act promulgated in defiance of international norms. And it is this principle that is to be weighed against the dangers to policy. Since deference and comity can conflict because the judicial vindication of international norms may disrupt foreign policy, there is no automatic exception to act of state for clear violations of international law. On the other hand, because act of state is not predicated upon deference alone, there is no automatic foreign policy exception to the responsibility of the courts to vindicate those norms. There is rather a weighing of the two. For a fuller discussion of the comity doctrine see note 61 infra.

31. Citibank, 406 U.S. at 773-76 (Powell, J., concurring).

32. See notes 6-8 supra and accompanying text, 
tion doctrine. Yet like Justice Rehnquist, he saw the protection of foreign policy as the central purpose of the doctrine. In reaching the same result as the plurality, he found support in a broader rationale. The American judiciary should, he contended, take a more active role in vindicating the substantive rules of international law and should especially aid in developing a "respected body" of law in what he characterized as a "long-neglected area." 33 Any fears that he may have shared with Justice Harlan in the abstract seem to have been sublimated in the hope of achieving progress through the judicial perfection of international law. Subtly, but unequivocally, he appears to have crossed the line from a narrow plea against Justice Harlan's particular assessment of the dangers in Sabbatino to a plea for a greater tolerance of those dangers.

More importantly, when the potential consequences of Justice Powell's decision are evaluated, it becomes clear that he did not share soine of the basic sensitivities underlying Justice Harlan's work. His preference as among competing private interests, his view of the public interest and his sense of danger to judicial integrity were all much more akin to Justice Rehnquist's ideas on these matters than to anything offered by Justice Harlan. Perhaps more adroitly than Justice Rehnquist, and certainly more subtly, Justice Powell seemed to have joined in the challenge to Sabbatino.

In light of the debate which surfaced in Citibank, it came as no surprise that when the Dunhill petition was filed, the Court appeared ready to reconsider Sabbatino. Dunhill arose out of the Cuban government's seizure (called "intervention") of certain Cuban owned cigar coinpanies. In a three-way suit, the lower courts held that the "interventors" (agents of the Cuban government) were entitled under the act of state doctrine to receive from three American importers all amounts due for cigars shipped after intervention. ${ }^{34}$ The district court, however, held that the importers had a claim against Cuba in quasi-

33. Citibank, 406 U.S. at 775 (Powell, J., concurring).

34. The controversy started when the former Cuban owners of the factories brought a number of actions to recover from the importers the value of these post-intervention shipments (approximately $\$ 700,000$ ) and for alleged trade-mark infringements. The interventors then sued to enjoin the law firm representing the owners from pursuing their actions. In this litigation the District Court held, inter alia, that since Cuba's seizure of its own citizens' property could not give rise to a violation of international law, the Hickenlooper/Sabbatino Amendment, 22 U.S.C. $\$ 2370(\mathrm{e})(2)$ (1970) (see note 21 supra), did not apply, and under Sabbatino, the act of state doctrme foreclosed any judicial scrutiny of the owner's claim that the seizure violated American public policy. $F$. Palicio y Compania, S.A. v. Brush, 256 F. Supp. 481 (S.D.N.Y. 1966), aff'd, 375 F.2d 1011 (2d Cir.), cert. denied, 389 U.S. 830 (1967). In that litigation it was assumed 
contract (unjust enrichment) for all payments on pre-intervention shipments (i.e., accounts receivable), which it said belonged to the former owners but which the importers had mistakenly paid to Cuba. ${ }^{35}$ On appeal the Second Circuit agreed with the Cuban government that the interventors' refusal to return these mistaken payments constituted an act of state, but relied upon Citibank to give each importer a right of set-off up to the amounts owed by it on the post-intervention shipments. ${ }^{36}$ Dunhill, one of the importers, appealed the limitation. It, unlike the other importers, had a counterclaim for mistaken payments that exceeded the sums owed Cuba by some $\$ 55,000$. Contending that Cuba's repudiation of the quasi-contractual obligation was not an act of state, Dunhill argued that it should properly be allowed to recover this sum out of the balances owed by other importers to Cuba. The Court gave judgment for Dunhill. ${ }^{37}$

Writing for the same plurality that joined Justice Rehnquist in Citibank, Justice White first concluded that the interventors' refusal to return the mistaken payments was not an act of state. ${ }^{38}$ He then proceeded to propose a blanket "commercial obligations" exception to the doctrine, relying upon the deference theory. The purpose of act of state was, he said, citing Sabbatino, ${ }^{38}$ to foreclose judicial actions that

by all concerned that any amounts owed by the importers on the date of intervention in respect of shipments prior to that date were insignificant. Later, however, it was discovered that those amounts were approximately $\$ 477,600$. It was the dispute over this sum that gave rise to the Dunhill litigation.

35. Menendez v. Faber, Coe \& Gregg, 345 F. Supp. 527 (S.D.N.Y. 1972), aff'd on this point sub nom. Menendez v. Saks \& Co., 485 F.2d 1355 (2d Cir. 1973).

36. Menendez v. Saks \& Co., 485 F.2d 1355, 1371-73 (2d Cir. 1973).

37. Dunhill, 96 S. Ct. 1854 (1976). In addition, the interventors had petitioned for certiorari, challenging the award of the pre-intervention accounts receivable to the former owners and the importers' right of set-off generally. Republic of Cuba v. Saks \& Co., No. 73-1287 (2d Cir. 1976). The other importers had also petitioned the Court to overturn the judgment against them on these amounts. Saks \& Co. v. The Republic of Cuba, No. 73-1289 (2d Cir. 1976). On the same day that it announced its decision, the Court denied both of these petitions. 96 S. Ct. 2201 (1976); see Dunhill, 96 S. Ct. at 1859 n.6.

38. Two grounds were cited by the Justice. First, such refusal was seen merely as a reiteration of their original claim to the pre-intervention accounts receivable. Second, there was, according to the Justice, no evidence in the record-no statute, decree, order or resolution-showing that the Cuban government had repudiated the obligation to repay the importers. Counsel's statcments to this effect were only a "litigating position," while the interventors themselves were only commercial agents not empowered to exercise sovereign authority. $96 \mathrm{~S}$. Ct. at $1860-61 \&$ n.8.

39. He also noted Justice Harlan's suggestion that the more certain the international law in question the more surely the courts may act, observing that in the matter of commercial dealings there is not the uncertainty that might attend the "exercises of governmental powers, including military powers and expropriations." Id. at 1866 (emphasis in original). 
might embarrass the Executive in the conduct of foreign relations. Taking note of the fact that the Executive had, apparently without peril to foreign policy, adopted the so-called "restrictive theory" of sovereign immunity (i.e.,' denied immunity in suits arising out of a foreign government's commercial operations) and noting the reasons behind that position, the Justice concluded that nothing in national policy required American courts to recognize a foreign government's repudiation of its commercial obligations. ${ }^{40}$

In a separate opinion Justice Stevens agreed that the interventors' refusal to return the mistaken payments was not an act of state, but declined to einbrace any sweeping commercial obligations exception to the doctrine. ${ }^{41}$ Justice Powell, perceiving difficulties in drawing the line between commercial and political acts, concurred separately. $\mathrm{He}$ emphasized that the central purpose of the doctrine was the avoidance of judicial "interfere[nce] with delicate foreign relations conducted by the political branches," concluding, on the basis of his Citibank opinion, that the allowance of Dunhill's claim posed no threat of such imterference. ${ }^{42}$

Writimg for the four Justices who dissented in Citibank, Justice Marshall imsisted that the interventors' refusal was not only an act of state, but an integral part of the expropriation of the cigar companies, and hence indistinguishable froin the seizure of the other assets of those firms situated in Cuba. It was, in other words, an act squarely within the Sabbatino interdiction. ${ }^{43}$ In rejecting Justice White's proposed commercial obligations exception, Justice Marshall relied principally upon Justice Brennan's Citibank dissent. Act of state, he emphasized, may serve purposes quite imdependent of the reasons for sovereign immunity, including the occasional identification of political questions not cognizable by the courts. Justice White's proposal was, according to Marshall, predicated upon reasons derived from an inapposite analogy whicl might very well intrude the courts into disputes constitutionally withheld from their purview. ${ }^{44}$

40. Id. at 1866-67.

41. Id. at 1871 (Stevens, J., concurring).

42. Id. (Powell, J., concurring).

43. Id. at 1878 (Marshall, J., dissenting).

44. Id. at 1876-77. Justice Marshall made two additional points. Dunhill's counterclaim, he asserted, was indistinguishable from an affirmative claim independent of any claim by Cuba. As such it was beyond the limited purview of the Citibank exception and squarely within the scope of Sabbatino. Id. at 1880. Second, in its brief the government of Cuba had supplied the Court with a letter from the Treasury Department, stating that under the Cuban Assets Control Regulations, 31 C.F.R. $\$ \$ 515.101$ et seq. (1963), the Department would not permit Dunhill to execute any judgment it might ob- 
Overall, it seems fair to view the Court as still evenly divided over the fundamental predicates of the act of state doctrine. The plurality, unable to command a majority favoring total subservience to the Executive, nevertheless used the deference theory to fashion an analogy to sovereign immunity and utilized that analogy to mount yet another broad attack on the Sabbatino holding. Justice Powell, while refusing to abandon his professed agreement with the broader principles of Sabbatino, has again evinced a willingness to apply those principles in a way that would seem incompatible with the basic sensitivities from which they were derived. If anything, his emphasis upon act of state as a means of avoiding embarrassments to foreign policy reflects a narrowing of his avowed disagreement with the plurality's thoroughgoing deference theory. The four dissenters remain unmoved in their insistence upon the broader Sabbatino formula and its constitutional underpinnings, while Justice Stevens has yet to commit himself on the fundamental issues.

\section{B. The Larger Implications}

As already noted, the basic theme of this Article is the wisdon of Sabbatino and the folly of the challenges to that decision. Such a conclusion, however, compels recognition of the fact that the act of state and political question doctrines are constructed from certain common ideas. In the interests it protects, the Sabbatino formulation reflects the same concern for judicial legitimacy that may be seen to underlie the political question doctrine. Both doctrines direct judicial mquiry along the same lines; both derive their reason and definition from the distinctive experience of the American nation under the separation of powers principle.

The equation is, however, only a sometime thing. Not every controversy over a foreign state act will qualify as a political question under the strict test of textual commitment to another branch of government. $^{45}$ And not every such controversy is likely to exhibit the largeness of subject which alone would seem to warrant abstention under a broader, more prudential view of the political question doctrine. ${ }^{46}$ Yet, even if these criteria are not met, Sabbatino, Citibank, and Dunhill serve to illustrate certain basic principles concerning international law, the international legal system and the role of domestic courts

tain against the funds paid to Cuba by the other importers. The Justice contended that Dunhill's claim was, therefore, virtually moot. Id. at 1881-82 \& nn.25-27.

45. See Powell v. McCormack, 395 U.S. 486, 519 (1969). See note 123 infra.

46. See Baker v. Carr, 369 U.S. 186, 267 (1962) (Frankfurter, J., dissenting). 
in transnational disputes which can supply persuasive reasons for extending act of state beyond the confines of a classic political question.

Much of the dissatisfaction with Sabbatino apparently rests upon a conviction that the rights of private property embodied in the traditional international law of expropriations-the so-called "non-discriminatory, full, prompt and adequate compensation" standard ${ }^{47}$-are rights to be preserved in any just ordering of international society and are rights, therefore, to which the Court should have lent its support. The conviction that these traditional rights are important is, as a personal preference, shared by the author. But the judicial role in vindicating those rights is a more complex inatter altogether. For when an international norn touches a subject about which American law has something to say, American courts may well find themselves engaged in a highly intricate problem of institutional and cognitive dynamics ignored by the challengers of Sabbatino and their animating convictions.

Thus, if a domestic court enforces international norms against a foreign government im the naine of some paranount set of values but refuses to call its own government to account on the saine basis, it has issued perhaps the ultimate expression of contempt for the judicial process. Yet the avoidance of such hypocrisy can present other and possibly more intractable difficulties. When a domestic court is presented a question with imphications for its own government's policies and those policies have been sanctioned by its own constitution, it is manifestly difficult for that court to judge the issue according to an antithetical international norin. Unless allowed to escape from judging, the court may well find itself acting as a negative force in the processes of international consensus building and conflict resolution. ${ }^{48}$

Where the conflicting international norn is supported by a strong consensus, the felt exigencies of the case may create a tension which will cause-imdeed, compel - the court to abandon, distort, or otherwise undermine that norm. On a more insidious level, a court may intrude its own narrow nationalistic perspective imto the task of fact perception and characterization. ${ }^{49}$

47. See, e.g., 8 M. Whiteman, Digest of InteRnational LAW 1143 (1967); REStatement (SECOND) OF Foreign Relations LAW of the UNTted States $\S 187$ (1965).

48. Compare Sabbatino, Citibank and Dunhill with Sardino v. Federal Reserve Bank, 361 F.2d 106 (2d Cir.), cert. denied, 385 U.S. 898 (1966) (upholding United States' freezing of Cuban assets in this country). For a fuller discussion of Sardino, see Part III. A. infra.

49. If disposed to view the disparity between domestic and international norms as evidence of the need for change in the latter, the question for the court is whether other institutions and processes are better fit to assume the role of advocate. 
Where consensus is lacking, the difficulties of escaping the advocate's role are even greater. - And while such a situation may offer an opportunity to aid in the developinent of a new and more adequate consensus, an imperfect resolution can, depending upon the subject, serve to polarize opinion and exacerbate existing difficulties. It may also undermine the use of existing norms to facilitate negotiation and compromise, results which those norms may nurture inore effectively than any rule the court can fashion in conformity to domestic law.

All of this was illustrated with some force in Citibank. The imtegrity of the American judiciary was very much at issue in that case. $^{\text {so }}$ The avoidance of a threat to that imtegrity, however, would have set the courts on a course of decision posing severe problems for American foreign policy, problems which the Legal Adviser's letter had ignored. ${ }^{31}$ In Dunhill, on the other hand, the interventors' refusal to return the mistaken payments was not treated as a violation of international law. The integrity of that law was not at stake, but the integrity of American law and of the American courts was involved, and the decision offers an intriguing opportumity for extending the lessons of Citibank.

Also runnimg through the opposition to Sabbatino is a sense that in that case the Court abdicated its duty to the litigants who had invoked its aid. Yet this sense rests, it would seem, upon a wholly unsophisticated propensity to equate a court's duty in a transnational dispute with its duty in a wholly domestic conflict. In the latter context, a court can usually assume that the equities which define its duty to the litigants will be the same for all persons similarly situated. It can generally assume that all those with comparable claims will have access to comparable rehef, if they choose to act in a timely fashion, and that its action on behalf of the hitigants will not work to the detriment of others equally deserving. In the transnational setting such assumptions may not be so readily indulged. Jurisdiction may be so fortuitous, remedial opportunities so episodic_-"piecemeal," as Justice Harlan put it $\mathrm{it}^{52}$-that justice for the litigants may become an act of injustice for non-litigants with equally ineritorious claims.

This was obviously Justice Harlan's concern when he spoke of the adverse effects that an adjudication might have upon efforts at a broader negotiated settlement of a particular controversy. But there are other dangers as well. Certainly, in defining its duty to litigants,

50. See notes 29-33 supra and accompanying text.

51. See note 7 supra and accompanying text.

52. See note 27 supra and accounpanying text. 
a court must consider what effect its decision may have on any remedial mechanism already established by the political departments, a requirement dramatically ignored in both Citibank and Dunhill. A court cannot disregard the possibility that the legal principles it is compelled to apply may so undercut other more adequate remedial devices that its effort to do justice in a single case becomes tantaniount to a positive act of injustice extending well beyond relations with a particular foreign government or a particular dispute over that government's actions.

In broader terms, the alleged failure of the Court in Sabbatino to vimdicate traditional values and to aid deserving litigants is seen as a failure of the Court to advance the rule of law among nations. ${ }^{53}$ Yet this criticism is rooted in a peculiar, and rather limited, view of law and the international legal order. It is a view central to Justice Rehnquist's deference-comity paradigm, and it asserts that the advance of the rule of law among nations is to be measured exclusively by national adherence to the rules of international law, secured largely through judicial action. Only when the nation's most urgent foreign policy objectives dictate otherwise are the courts to stay their hand.

It is a simple formula which, in Falk's apt phrase, equates the "extension of law in international relations ... with the maximum application of universal substantive standards." ${ }^{.54}$ Any danger that the equation might prove unworkable is seen not as imvalidating the equation but only as evidence of a defect in extant rules which the courts can with diligence overcome. The formula necessarily draws heavily upon a view of law as rules, and then only such rules as are vouchsafed judicial enforcement. It rejects as a contradiction in terms any thought that the rule of law among nations may depend less upon the judicial enforcement of international legal norms than upon a deliberate refusal to do so in the proper case. That the courts might so refuse in order to protect foreign policy is a concession to expediency yielded up grudgingly, a matter of mere deference whose purview is to be defined as narrowly as possible. ${ }^{\text {s5 }}$

53. Sabbatino, 376 U.S. at $439-41$ (White, J., dissenting).

54. R. Falk, The Role of Domestic Courts in the International Legal Order 5 (1964).

55. For some of the better known and more forceful critiques of the older tradition, consult M. Kaplan \& N. Katzenbach, The Political Foundations of International LAW (1961); Hoffman, International Systems and International Law, in THE INTERNATIONAL SYSTEM (K. Knorr \& S. Verba eds. 1961); McDougal, International Law, Power \& Policy: A Contemporary Conception, 82 Recuen, DES Cours 133 (1953). 
The view that the act of state doctrine rests on constitutional underpinnings, on the other hand, is rooted in a rejection of this positivist perspective which has too long plagued international legal thought. It begins, instead, by accepting the possibility that the enforceinent of international legal norms by doinestic courts may neither serve justice nor secure a more viable international order. It refuses to define this possibility solely in terms of disrupting foreign policy, insisting that courts can serve the cause of justice and good order only as they pay strict attention to the constitutional foundations of their own legitimacy. Above all else, it rehes upon a highly comprehensive perspective in which the international legal system is seen as a multiplicity of institutions and processes, of diploinats and pohtics no less than of courts and decisions by reasoned principles. It implies that the rules of international law are not ends in theinselves to which nations owe an unvarying obligation of conformity, but facilitative devices serving a variety of purposes. They may serve as principles for the reasoned decisions of courts. But as reflections of community expectations they may only serve to bring nations to the negotiating table, or act as weights in the calculus of bargain and compromise. It implies, in short, that the progress of law is not to be equated with the progress of rules but with the progress of justice and good order and that, therefore, constitutional legitinacy is an inextricable element in the search for law in the international coinmunity.

Finally, it is true that because act of state deals with "laws in space," as Beale aptly defined the general province of the conflict of laws, ${ }^{50}$ it nuay be thought of as merely another conflicts rule. On the other hand, such a characterization adds nothing to understanding. In fact, it can mislead if it results in a denial of the doctrine's unique constitutional underpinnings and invites attempts to fix the ambit of the doctrine by reference to the modalities and policies usually employed in fornulating more traditional conflicts rules. ${ }^{57}$ At the same time, of

56. $1 \mathrm{~J}$. Beale, A Treatise on the Conflicts of LaW $\S 1.1$ (1935).

57. For perhaps the most extended effort to fit act of state within traditional private international law rules, see Mann, The Sacrosanctity of the Foreign Act of State, 59 L.Q. REV. 42 (1943). The effort, on the whole, does not succeed, being dependent upon a quite extraordinary reading of the leading British case, Duke of Brunswick v. King of Hanover, 9 Eng. Rep. 993 (H.L. 1848), and upon the insistence that Underhill v. Hernandez, 168 U.S. 250 (1897), was actually decided on sovereign immunity grounds. Mann's analysis is also based on a wholly inapposite comparison which at once approved the decision of a Belgian court, de Bauffremont v. de Bauffremont, [1880] Arrets des Cours d'Appel, Recueil General 319 (Bruxelles), which passed upon the validity of a German naturalization decree as preliminary to determining the validity of a inarriage, and criticized the refusal of a Dutch court in Papadopoulos v. N.V. Koninklijke Nederlandsche Stooinbootmaatschappij, [1925-26] Ann. Dig. 27 (No. 19) (Dist. Ct., Am- 
course, there is an intimate operational relationship between act of state and these rules, a relationship considered at several points in this Article. ${ }^{58}$

Likewise, references to international comity as a predicate for act of state can mislead. The reference is often quite meaningless. Any time the doctrine is applied, a court is granting comity to a foreign state act, but why it should do so remains unexplained. ${ }^{59}$ If, however, comity is seen, under Justice Story's view, ${ }^{\circ 0}$ as the principle undergirding all of the more traditional conflicts rules, and the reference to comity is a shorthand means for denying the doctrine's umique constitutional predicates, it will not do. And, if the reference is to the elements in the broader Storian prescription, there is good reason to suggest that act of state is wholly distinct froin comity. ${ }^{61}$

Within the frainework established by these larger implications of the Court's debate, we turn to the cases.

sterdam), aff'd on other grounds, [1927-28] Ann. Dig. 34 (No. 17) (Ct. App., Amsterdam), to review a charge of embezzlement against the British occupation forces in Turkey. At bottom the attempt confessed its own analytic weakness with the following statement:

On the other hand, it is, of course, understandable that a judge will be reluctant to question and perhaps condemn a foreign act of State. But this is a somewhat political consideration which, in the last resort, will often weigh heavily with him but which should not be allowed to be twisted into a denial of his powers ... Mann, supra, at 52-53.

Surely, it is the province of legal scholarship to consider what weighs heavily with the judges, to pursue the implications of what judges do, and to work these considerations into a doctrinal form that will aid in formulating principled decisions which are also responsive to reality. Compare the development of a wholly contrary point of view in Holdsworth, The History of Acts of State in English Law, 41 CoLUM. L. REv. 1313 (1941). Act of state, Holdsworth concludes, is an emanation of the English Constitution.

58. In general terms the relationship has the following incidents. As Justice Harlan's holding indicates, the act of state doctrine does not normally apply to extraterritorial acts of a foreign sovereign. Not infrequently, therefore, the courts are compelled by this principle to consult traditional conflicts rules for guidance in fixing the situs of the property or transactions affected by a foreign state act. Those rules serve as a "trigger" to the doctrine except in the narrow category of cases where the territorial limit is to be ignored. Moreover, all challenges to a foreign state act must rest upon some assertion of a right derived from some law, either international or municipal. Where it is the latter, (e.g., Dunlilll), a court may very well be compelled to resort to traditional choice of law rules before it can determine whether there is any issue for it to resolve. The discussion in Part V of this Article suggests an important relationship between act of state and the traditional conflicts rule against the enforcement of foreign "penal" laws.

59. See, e.g., Laylin, Justiciable Disputes Involving Acts of State, 7 INT'L Law. 513 n.2 (1973).

60. J. Story, Commentaries on the Conflict of LaWs $\$ 38$ (5th ed. 1857).

61. Drawing upon the axioms of the great seventeenth century Dutch jurist, Huber, Story asserted that the question of when the courts of one nation will recognize the laws 


\section{Justice for AMERICAN Claimants}

\section{A. The Citibank Decision}

In his letter to the Court in Citibank, the Legal Adviser suggested that since foreign policy did not necessitate resort to the act of state doctrine in that case, "considerations of fairness and equity" required

of another is a matter of the comity-not the law-of nations. Id. $\$ \$ 29$ et seq. It is the product of an "ought" rather than of "obligation superseding all discretion." The reason for the distinction was self-evident: "[E]very nation must judge for itself, and certainly is not bound to recognize [foreign laws], when they would be prejudicial to its own interests." Id. $\$ 36$ at 43. Yet, this sense of "ought" is rooted in the same considerations that give rise to international law. It is derived, Story suggested-and here the criteria for its application emerge-"from mutual interest and utility, from a sense of the inconveniences which would result from a contrary doctrine, and from a sort of moral necessity to do justice, in order that justice may be done to us in return." Id. $\$ 35$ at 42 . As a reflection of mutual utility and reciprocity, therefore, the actual practice of comity traces its "origin and authority" to the "consent of nations." Id. $\S$ 36 at 43 .

The difficulties of working act of state into this formulation are best illustrated by Justice White's dissent in Sabbatino. Anxious to find an international predicate for act of state, Justice White argued that the doctrine rests upon "the deeply imbedded postulate in international law of the territorial supremacy of the sovereign." 376 U.S. at 445. Other nations, without act of state, use this postulate to "afford substantial respect to acts of foreign states." All that act of state does is to foreclose a "challenge to ... . foreign law on the ordinary conflict of laws ground of repugnancy to the public policy of the forum." It merely takes the "deeply embedded" territorial concept "one step further." Id. at 446.

But this is remarkable. If the "territorial concept" is descriptive of a nexus between a foreign law and its objects which serves to lend that law's demand for recognition a certain persuasive force-but not a force sufficient to overcome its repugnance to the "public policy" of the forum-the obvious question is why the American courts under act of state have found that persuasive force undiminished even if repugnant to pohicy; why have they taken the "one step further"? It is not a step, Justice White noted, supported by any consensus raising it to an obligation of international law. Even if it were said that the American practice represented the leading edge of an evolving international consensus, it must still be asked what considerations underlie that movement. If one then searches further for some footing in that mutual necessity, convenience and reciprocity which Story thought underlay international comity, one must still ask what distinguishes the American perception of those expedients from the perception Justice White attributes to the rest of the world.

Curiously, and quite unintentionally, Justice White supplies the answer. The balance of his opinion is devoted to fashioning a particular view of the international legal systein and of the place of norms in that system, in order to demonstrate that the cause of international order would best be served if courts paid greater heed to their constitutional task of deciding controversies on the merits and less attention to the problems of judicial legitimacy which so animated Justice Harlan. Moreover, White nowhere ad. vocates an automatic "international law exception" to act of state. He does not argue that because act of state rests upon an international predicate, it should be set aside in the face of foreign state acts which are themselves expressions of disrespect for the precepts of international justice. His quarrel is not with act of state itself, but with the scope given to it by Justice Harlan. And the scope he would assign the doctrine is ulti- 
that it not be applied. ${ }^{62}$ Judge Lumbard, in reviewing the matter both before and after the Legal Adviser had intervened, however, thought that equity had another dimension. Banco Nacional had sued to recover approximately $\$ 2$ million of excess proceeds remaining after First National City Bank of New York (the "Bank") had sold and applied certain collateral against the unpaid balance of its $\$ 10$ million loan to Banco Nacional. By way of counterclaims the Bank sought to offset against this $\$ 2$ million the value of Bank properties located in Cuba and seized by the Castro government allegedly in violation of international law. It was to these counterclaims that Banco Nacional had interposed the act of state doctrine. ${ }^{63}$ Critical to Judge Lumbard's appraisal was the fact that if judgment had been given to Banco Nacional, the $\$ 2$ million would have been blocked under the Cuban

mately derived from his view of the constitutional responsibilities of the courts. Thus, the answer to why the American courts have taken the "one step further", is that in consulting their own constitutional traditions, they have in particular cases set aside those practices which reflect the consensual "ought" upon which Storian comity rests in favor of a more generous posture. If one must speak of comity-of that "ought" flowing from mutual necessity, convenience and reciprocity-it is that traditional practice of states which defines the limits of comity, and the rejection of that practice under the press of constitutional considerations, that explain the rise of the act of state doctrine.

This is not to suggest that act of state could not be predicated upon the broader Storian formula. The basic elements in the controlling constitutional perspective just reviewed all reflect a concern for the quality of the international order. One can argue that a fully matured act of state doctrine would so serve the needs of the international community that it should rest upon an international predicate. But plainly, this perception is not shared by the majority of states in that community. The reason lies in the disparate nature of national legal systems which makes it difficult or unnecessary for national courts to effect a linkage between the elements of constitutional legitimacy within a democratic order and the search for law in the international community. Even were a consensus around this point to emerge, the ultimate standard would remain constitutional. On comity generally see Katzenbach, Conflicts on an Unruly Horse: Reciprocal Claims and Tolerances in Interstate and International Law, 65 YALE L.J. 1087 (1956), and Yntema, The Comity Doctrine, 65 Mich. L. REv. 9 (1966).

62. Letter from John R. Stevenson, supra note 7.

63. In Citibank the district court had held for the Bank on the ground that the case was covered by the Hickenlooper/Sabbatino Amendment. Banco Nacional de Cuba v. First Nat'l City Bank, 270 F. Supp. 1004, 1007-10 (S.D.N.Y. 1967). That statute requires the courts, notwithstanding the act of state doctrine, to make a determination on the merits of any claim of right to property confiscated by an act of a foreign state in violation of international law, unlcss the President files a suggestion with the court that application of the act of state doctrine is required in the interests of foreign policy. 22 U.S.C. $\$ 2370(e)(2)(1970)$. This decision was reversed by the Second Circuit in an opinion written by Judge Lumbard. 431 F.2d 394 (2d Cir. 1970). The Supreme Court then granted certiorari and remanded to the Secoud Circuit for consideration of the Legal Adviser's letter. 400 U.S. 1019 (1971). The Second Circuit, again speaking through Judge Lumbard, declined to change its earlier determination, 442 F.2d 530 (2d Cir. 1971), and the Supreme Court reversed. 
Assets Control Regulations. ${ }^{64}$ Assets blocked and later "vested" in the governinent have often provided the principal source of general redress for all American claimants in cases of this sort. ${ }^{65}$ Thus, the Bank's attempt to avoid the act of state doctrine represented to Judge Luinbard nothing less than a demand for a preference over other Americans who had also suffered from Castro's expropriations. ${ }^{68}$

The point to note is that all American claimants against Cuba, as a group, had and continue to have certain expectations with regard to blocked funds. These expectations are based upon a considerable history supported by official action, although without any official commitment to make the funds available for the payment of claims.

64. 31 C.F.R. $\S \S 515.101$ et seq. (1963). Under the blocking regulations, the funds payable to the Cuban bank would have been frozen in the United States and made available to satisfy American claims arising out of the Cuban expropriation program.

65. Blocked assets have been used principally to satisfy American claims against the Soviet Union and other Eastern European countries. The settlement of claims against the Soviet Union was effected exclusively out of the assets in the United States assigned to this country under the Litvinov Assignments. See note 100 infra. A number of settlement treaties with Eastern European countries are outlined in H. STEINER \& D. VAGTS, Transnational Legal Problems 433-34 (2d ed. 1976). In 1948 Yugoslavia agreed to the establishment of a $\$ 17$ million fund for the payment of claims; ninety per cent of this amount was represented by blocked assets. Treaty with Yugoslavia on the Setttlement of Pecuniary Claims Against Yugoslavia, July 19, 1948, 62 Stat. 2658 (1948), T.I.A.S. No. 1803. Yugoslavia later agreed to pay $\$ 3.5$ million against additional claims. Treaty with Yugoslavia on Claims of United States Nationals, Nov. 5, 1964, [1965] 1 U.S.T. 1, T.I.A.S. No. 5750. In settlement of American claims Rumania agreed to pay $\$ 2.5$ million and consented to the establishment of a fund of $\$ 22$ million from vested assets located in the United States. Treaty with Rumania on Settlement of Claims of United States Nationals and Other Financial Matters, March 30, 1960, [1960] 1 U.S.T. 317, T.I.A.S. No. 4451. Bulgaria agreed to a settlement of $\$ 3.5$ million, of which only $\$ 400,000$ was paid by Bulgaria. The balance came from vested assets. Treaty with Bulgaria on Claims, July 2, 1963, [1963] 1 U.S.T. 969, T.I.A.S. No. 5387. In the case of Hungary, settlement was to be made out of $\$ 3,320,000$ of vested assets and $\$ 18.9$ million paid by Hungary. Treaty with Hungary on Settlement of Claims, March 6, 1973, [1973] 1 U.S.T. 522, T.I.A.S. No. 7569. Poland agreed to the payment of $\$ 40$ million of American claims in exchange for the release of blocked assets and other U.S. undertakings. Treaty with Poland on Settlement of Claims of United States Nationals, July 16, 1960, [1960] 2 U.S.T. 1953, T.I.A.S. No. 4545. Total claims against Poland were fixed by the Foreign Claims Settlement Commission at $\$ 151,789,507$. Foreign Clams Settlement Comm’n Decisions \& Annotations 457 (1969). In the case of Bulgaria, Hungary and Rumania, American clainants were paid out of vested assets before any general settlement was reached with the foreign government. See generally Legislative Reference Service, Library of Congress, Report to the House COMm. ON Foreign AfFatrs, 88Th CONG., 1ST SESS., Expropriation OF American-OWNed Property by Foreign Governments in the Twentieth Century (Comm. Print 1963), reproduced in 2 INT'L Legal Materials 1066 (1963); R. Liflich, THE Protection OF Foreign INVESTMENT (1965).

66. Banco Nacional de Cuba v. First Nat'1 City Bank, 431 F.2d 394, 403-04 (2d Cir. 1970), on remand, 442 F.2d 530, 534-35 (2d Cir. 1971). 
Thus, shortly after issuance of the Cuban Assets Control Regulations, Congress authorized the Foreign Claims Settlement Commission to determine the amount of individual claims against Cuba. ${ }^{67}$ Historically, this procedure has, with one exception, been a prelude to the later negotiation of a lump-sum settlement of claims, with blocked assets invariably serving as a principal measure and even source of payinent.

The courts have also lent their support to claimants' expectations. In Propper v. Clark, ${ }^{68}$ a "freezing" order was held to prohibit the courts of New York froin transferring the assets of a foreign corporation to a receiver in liquidation until the Government could determine whether the assets were needed "to compensate our citizens . . . for the damages done by the government of the nationals affected." v. Federal Reserve Bank, ${ }^{70}$ the constitutionality of the Cuban Assets Control Regulations was upheld, in part, upon the authority of Propper v. Clark and the "unquestionable right of a state" to protect its nationals in their persons and property in a foreign country. ${ }^{71}$ Surely, if the purpose of protecting American citizens is necessary to sustain the constitutionality of a seizure of foreign assets, the Americans to be protected by that seizure might be thought to have a certain "entitlement" 72 to the assets seized. Until deliberately returned to the original

67. 22 U.S.C. $\S 1643$ (Supp. I, 1965), amending 22 U.S.C. $\$ 1643$ (1964). The amendments provided for determination of the amount and validity of claims against the government of Cuba by U.S. nationals.

68. 337 U.S. 472 (1949).

69. Id. at 484. If in Propper v. Clark the purpose of securing the payment of American claims against a foreign government was a purpose sufficient to deprive the American creditors of a foreign corporation any rights in blocked assets, one wonders whether the Citibank Court's willmgness to give the Bank benefit of assets that would otherwise be blocked (i.e., put the Bank ahead of other claimants) signals a willingness to reverse Propper.

70. Sardino v. Federal Reserve Bank, 361 F.2d 106 (2d Cir.), cert. denied, 385 U.S. 898 (1966).

71. 361 F.2d at 112-13.

72. Arguably, because the Treasury's claim of right to blocked assets is dependent upon foreign ownership and therefore subject to any defects in the foreign owners' title, those American claimants who have no prior title in the specific assets before a court have no greater right to those assets than either the Treasury or the foreign government. Arguably, in other words, those claimants have no rights of which they could be deprived if a court, refusing an act of state plea, were to sustain the former American owner's assertion of a defect in the foreign government's title.

Of course, in Citibank, the Bank was not laying a claim of prior title to the bond proceeds, but was, as Henkin has observed, suing upon an "international tort." Henkin, Act of State Today: Recollections in Tranquility, 6 CoL. J. Transnat'L LAW 175, 184 (1967). Hence this argument cannot be employed in defense of the decision in that 
owners or applied to some other public purpose, that interest might even be thought to bear some analogy to such unguaranteed expectations as that of a welfare recipient in an on-going welfare program, ${ }^{73}$ the interest of a tenured teacher ${ }^{74}$ or a government employee ${ }^{75}$ in his job, or that of a student in his publicly financed education. ${ }^{76}$

Against this background the questions left unanswered by the Court in Citibank proliferate. What answer is to be given to Judge Lumbard's suggestion that judgment for Citibank would conflict with the policy declared in the Trading With the Enemy Act and the Cuban Assets Control Regulations? ${ }^{77}$ Since the Legal Adviser was competent to speak only about the effects of an adjudication upon foreign policy, was his letter even germane to the Court's responsibilities under those enactments? If, under the deference theory, the Executive could control application of the act of state doctrine, might not other American claimants adversely affected by that control have a constitutional right to be heard on the issue? ${ }^{78}$ After all, the Legal Adviser clearly had a view of what fairness required. Could his view of foreign policy have been affected by his view of justice?

case. Nevertheless, it is applicable to cases like Sabbatino and to situations covered by the Hickenlooper/Sabbatino amendment. But the argument begs the question. It takes the notion of "title" as used by the American legal system to resolve conflicts within a framework of respect for private property and transports it uncritically into an international conflict between sovereign states where, other means of settlement having failed, the United States determines to disregard this tradition of respect and subject all of the property of the other sovereign state withm its territory to the redress of its citizens' grievances. Since both groups of American investors are equally aggrieved, the argument is simply another way of saying that those whose confiscated products enter the American market are, within the framework of this new and extraordinary remedial regime, entitled to a preference over those not so fortunate. Actually it is an argument that the act of state doctrine should not apply because that decision would maximize the prior owner's recovery at the expense of others aggrieved. If there is some rational basis for this result it is to be found in the purposes and objectives underlying the new remedial regime or elsewhere in public policy, and not in the entirely fortuitous fact that the foreign government happened to bring the expropriated property or its products into the United States from which point some claimants can formulate their grievances in terms of a claim to prior title.

73. See Goldberg v. Kelly, 397 U.S. 254 (1970).

74. See Perry v. Sindermann, 408 U.S. 593, 599-601 (1972); Board of Regents v. Roth, 408 U.S. 564 (1972) (dictum); Slochower v. Board of Higher Educ., 350 U.S. 551 (1956).

75. See Arnett v. Kennedy, 416 U.S. 134, 151-53 (1974); id. at 166-68 (Powell, J., concurring); id. at 171 et seq. (White, J., concurring in part); id. at 203 (Douglas, J., dissenting): $i d$. at 206-10 (Marshall, J., dissenting).

76. See Goss v. Lopez, 419 U.S. 565, 572-76 (1975).

77. See Banco Nacional de Cuba v. First Nat'l City Bank, 431 F.2d 394, 403-04 (2d Cir. 1970).

78. See cases cited in notes 73-76 supra. 
Moreover, having authorized the establishment of an extraordinary remedial regime largely for the benefit of Americans injured by Cuba's action, could the Government, through any of its branches, exempt certain assets from the operation of that regime solely to favor one set of equally aggrieved Americans over another? There is something disturbingly discriminatory and imequal about such an action, intuitively suggesting equal protection and due process problems. On the other hand, the alien and complex political and economic milieu in which governmental efforts to facilitate the redress of imvestors' grievances occur, and the potential impingement of those efforts upon foreign policy, all caution against any easy answers to the question.

Following the example of the Second Circuit, which did not even consider the point in upholding the constitutionality of the Hickenlooper/Sabbatino anendment, ${ }^{79}$ all questions concerning the substantive validity of that amendment in this aspect of its operations are set aside. Nevertheless, the issue of fairness remains. All the Justices appeared to agree that the Hickenlooper/Sabbatino amendment was not apphicable in Citibank. It was only the fairness of the Court's own actions that was at issue in that case. The setting was limited and the controlling principle quite clear. The idea that governmental means inust bear some rational relationship to governmental ends represents, it is suggested, an irreducible core in the nation's defenses against arbitrary official action. And by this standard, the hard question is whether the adjudication in Citibank and the consequent injury to other claimants represented a rational advance toward any larger public purpose whatsoever.

For purposes of argument it may be conceded that, in the general case, a number of legitimate public purposes might be served by having the courts pass on the legality of foreign expropriatory decrees. Foreign governments would be prevented from marketing in the United States property taken from Americans in violation of international law. The United States would be prevented from becoming, as Senator Hickenlooper called it, a "thieves market." ${ }^{\prime 0}$ Unless immune, any property of such a government located in the United States would be made available for the redress of American grievances. The knowledge that they would be denied access to the American market or would lose assets held in the United States might deter governments from confiscating

79. See Banco Nacional de Cuba v. Farr, 383 F.2d 166 (2d Cir. 1967), cert. denied, 390 U.S. 955 (1968); see note 63 supra.

80. 110 CoNG. REc. 19, 555 (1964) (remarks of Sen. Hickenlooper). 
American property. Such denials might even promote the settlement of disputes and aid the Executive in its negotiations.

Granting all of these possibilities arguendo, the difficulty is that the decision in Citibank does not seen to bear a rational relationship to any one of them. Long before that case, the blocking of Cuban assets had practically foreclosed Cuba from the American market and denied it the use of any assets located in this country. Only in the case of property entering the country in the hands of an American or thirdcountry purchaser froin Cuba, where payment had been made outside the United States, might an adjudication have added to the realization of those objects. But this was not the case in either Sabbatino or Citibank. And while the larger deterrent and protective purposes might be served by a general rule allowing courts to adjudicate where foreignowned assets had not been blocked, if blocking had already occurred, an adjudication would not advance those purposes one whit. It is hardly necessary to give one American a preference over others in assets that would otherwise be blocked in order to demonstrate to foreign governments that the courts will act where blocking is not a threat. $^{81}$

In sum, if rationality in judicial means depends upon effecting some advance toward a legitimate judicial end, the decision in Citibank seems irrational when judged by these preventive and deterrent purposes. There is an element of arbitrariness here that can hardly escape due process inquiry.

And so the question persists. What other public purpose might have been served by the adjudication of Citibank's counterclaims? Vindication of the Bank's rights under international law or vindication of that law more generally are purposes which beg the question. The

81. In this context the Legal Adviser's suggestion that an adjudication would aid the Executive in protecting American investors is scarcely to be believed. Perhaps he expected the Court to sanction the traditional non-discriminatory, full, prompt and adequate compensation standard espoused by the Department. But that was a large assumption in light of Justice Harlan's comments in Sabbatino. As discussed in Part In, it was a dangerous assumption as well. Moreover, as far as the particulars of the Citibank controversy are concerned, he nowhere explains why an adjudication would have an added protective or deterrent effect where the foreign government was already foreclosed from the American market. Nor does he say how an adjudication in Citibank would add to the credibility of a rule permitting the courts to act where blocking had not occurred. Finally, the advantage he deduced is carefully confined to cases where the American owners' rights had been asserted as a counterclaim in a suit initiated by the foreign government. Yet, if an adjudication positively aids in the protection of foreign investments, that advantage would seem to argue for permitting claimant-initiated suits rather than waiting upon the fortuitous possibility of the foreign government imitiating the action. 
issue is one of choosing between the Bank's expectations under international law and the expectations of other claimants fostered under the regime established by Congress. To cite one set of expectations does not explain a denial of the other. Ironically, in their anxiety to uphold international law, the challengers were quite prepared to disregard American law. And in the context of this, the real choice in the case, there was soinething distorted in the Bank's appeal ${ }^{82}$ to the holding in National City Bank v. Republic of China ${ }^{83}$ which Justice Douglas had embraced. ${ }^{84}$ The equities that dictate setting aside the defense of sovereign immunity in a suit commenced by a foreign governinent bear no resemblance whatsoever to the equities in Citibank.

The unanswered questions therefore remain. Significantly, it is the existence of the questions, quite apart fron the answers, that establishes the inadequacy of the deference-comity theory. It is well to keep in inind that if the answers ultimately denionstrate that the Bank was in fact deinanding an unjust preference, then, given the Court's view of the pleadings, ${ }^{85}$ application of the act of state doctrine was the

82. Petitioner's Brief at 6, Citibank, 406 U.S. 759 (1972).

83. 348 U.S. 356 (1955).

84. Citibank, 406 U.S. at 770-73 (Douglas, J., concurring); see note 15 supra.

85. As already observed, see note 72 supra, the Bank, unlike C.A.V. in Sabbatino, was not laying a claim of prior title to the bond proceeds. It was essentially asserting a claim in tort, predicated upon interuational law, see Henkin, supra note 72 . Hence, had that claim been adjudged a demand for an unjust preference, whether constitutionally proscribed or not, the case might have been disposed of without invoking the act of state doctrine. It might have been said that the Bank simply had no cause of action, and that Banco Nacional's title to the bond proceeds was clear under the terms of the pledge agreement construed according to New York law. At this point those proceeds would have been blocked. Such a decision would not, of course, have prejudiced the Bank's right to assert its claim before the Foreign Claims Settlement Commission or to share in any remedies eventually established by Congress or the Executive (contrast the problem in Dunhill described at note 174 infra). Nevertheless, the Court apparently assumed that the Bank had an otherwise valid cause of action, and the question was treated as though act of state were Banco Nacional's only defense to that claim. In this posture, act of state was essential to forestall the unjust preference.

It is to be noted that in cases such as Sabbatino, act of state could not have been avoided in this fashion. There Banco Nacional's title to the sugar proceeds rested exclusively upon Cuban Law 851 and the implementing decrees of the Cuban governinent. Any denial, therefore, of C.A.V.'s claim to title on the ground that such a claim was a demand for an unjust preference would not have sufficed to permit blocking, even if that denial were said to rest on the Constitution. It would still have been necessary to affirm Banco Nacional's title on the ground that Law 851 supplied the controlling rule of decision in the case. Act of state in this context served two purposes: (i) it foreclosed any judicial pronouncements regarding the validity of $\mathrm{Law} 851$ (i.e., it served as a rule of abstention), and (ii) it supplied the conflicts rule necessary to achieve a just result. On this latter point consult Ricaud v. American Metal Co., 246 U.S. 304, 309 (1918). For the reasons why C.A.V.'s claim in Sabbatino also constituted a demand for an unjust preference, see note 72 supra. For a fuller discussion of the act of 
only means of forestalling that demand. Yet, if the only purpose of the doctrine is to secure to foreign governments a proper respect for their acts (i.e., comity) or to guard against judicial cmbarrassments to foreign policy (i.e., deference), the doctrine is rendered impotent to perform either function. The defect in Justice Rehnquist's opimion, in other words, lies not only im his failure to answer the question but more fundamentally in the fact that his theory excluded the question from judicial review altogether.

\section{B. The Dunhill Decision}

As in Citibank, all of the set-offs allowed the importers in Dunhill (not just Dunhill's $\$ 55,000$ excess) effectively reduced the ainounts that would have been available, through blocking, for the general redress of American claims against Cuba, a point acknowledged by the Second Circuit ${ }^{86}$ and made clear by the Treasury letter. ${ }^{87}$ Nevertheless, the cases are arguably different.

It will be recalled that Cuba had purported to expropriate the accounts receivable to whicl the importers' mistaken payments related. The payments preceded any judgment disallowing Cuba's claim to those accounts and were in the opinion of the district court based upon a.mistake of law. All but $\$ 40,000$ was paid through New York banks ${ }^{88}$ and not remitted directly through Cuban banking channels. Whatever other motives they may have had, the importers had arguably not exposed themselves to the vagaries of a foreign legal and political system with the deliberateness that characterized the actions of the Bank or most of the other victims of Castro's decrees. There was, in other words, an arguably rational basis for granting to the importers a preference over the other claimants.

This he of reasoning, of course, supplies the basic justification for the preference implicit in any denial of extraterritorial effect to a foreign state act where the assets would otherwise be blocked. And it is a line of reasoning that finds support in the Cuban Insurance Cases. ${ }^{80}$ There, the fact that, under the policies, benefit payments

state doctrine as supplying the controlling conflicts or choice of law rule, see note 251 infra.

86. Menendez v. Saks \& Co., 485 F.2d 1355, 1373 (2d Cir. 1973), rev'd sub nom. Alfred Dunhill of London, Inc. v. Republic of Cuba, 96 S. Ct. 1854 (1976).

87. See note 44 supra.

88. 485 F.2d at 1367 n.16.

89. See, e.g., Pan-Am. Life Ins. Co. v. Blanco, 362 F.2d 167 (5th Cir. 1966), cited as controlling, Oliva v. Pan-Am. Life Ins. Co., 448 F.2d 217, 220 (5th Cir. 1971); PanAm. Life Ins. Co. v. Recio, 154 So. 2d 197, 199 (Fla. Dist. Ct. App.), cert. quashed, 156 So. 2d 857 (Fla. 1963), cert. denied, 377 U.S. 990 (1964); Theye y Anjuria v. Pan- 
were to be inade at the insurance companies' home offices in the United States or Canada, frequently in dollars, was thought to show that these insured had dehiberately contracted for protection against the vagaries of the Cuban political and economic system. This was used, in turn, to justify visiting on the companies, not the insured, the loss occasioned by Castro's expropriation of the companies' Cuban reserves, although the insured individuals were at the time of contracting residents of Cuba.

The analysis, however, cannot end here. The whole problem in Dunhill arose only because the lower courts, under a wooden application of the territorial limitation, denied Cuba's act of state claim to the pre-intervention accounts receivable. The only effect of this denial was to shift the loss of those accounts from the original Cuban owners to the importers and then, by granting the latter a set-off, to all other Americans with claims against Cuba. Cuba obtanied the money in all events, while the original Cuban owners of the confiscated firms obtained a preference as aganist the American victims of Castro's deprivations. A curious result at best, and certainly not one necessitated by established principles. ${ }^{90}$

The broader lesson seenis plain. In dealing with transnational disputes, particularly disputes over foreign expropriatory acts, the courts cannot disregard the impact of their decisions on alternative remedial inechanisms established by the pohtical departments of the Government. To the extent that act of state is essential to preserving those mechanisms, it is responsive to the fact that in the international sphere, the judicial power is subject to certain very practical limitations. Its purpose is to secure, in light of those limitations, that working relationship between the departments of government which will best serve the ends of justice. Even if, in this single aspect, the doctrine does not signal the presence of a political question, it nevertheless has constitutional underpinnings which no theory of deference to the Executive can adequately embrace.

\section{Law, Policy and the Political Question}

With the decision to block Cuban-owned assets located in this country, the Government of the United States embarked upon a policy which eventually forced some unenviable choices upon the courts: choices among international law, foreign policies pursued under constitutional warrant, and their own decisional integrity. Lurking just

Am. Life Ins. Co., 245 La. 755, 161 So. 2d 70 (1964). But cf. Confederation Life Ass'n v. Ugalde, 151 So. 2d 315 (Fla. Dist. Ct. App. 1963), rev'd in part, 164 So. 2d 1 (Fla. 1964); Dougherty v. Equitable Life Assurance Soc'y, 266 N.Y. 71, 193 N.E. 897 (1934).

90. For a broader discussion of "territorial limitations" see Part V.C. infra. 
beneath the surface, these choices were all but ignored in both Citibank and Dunhill. Since, however, the courts did not treat the refusal to return the importers' payments in Dunhill as a violation of international law, the cases must be analyzed separately. Citibank, in particular, illustrates the extent to which a concern for the progress of law in the international community and an equal regard for judicial legitimacy may be joined in the act of state doctrine.

\section{A. Citibank-Of Cuban Confiscations and American Deprivations}

In contrast to the insensitivity of the courts, the political departments early exhibited some uneasiness with the position into which they were working themselves with the passage of the Cuban assets control legislation. In 1964 Congress amended the International Claims Settlement Act to include a provision vesting in the United States all Cuban government assets that had been blocked the year before. ${ }^{91}$ The following year, the Executive proposed eliminating this provision on the ground that "vesting . . . could set an unfortunate example for countries less dedicated ... to the preservation of property rights." It could, the State Department said, "place the Government of the United States in the position of doing what Castro has done." ${ }^{22}$ Congress agreed, and the vesting provision was eliminated. ${ }^{93}$

But Cuban-owned assets remamed blocked, and the distinction between vesting and blocking proved to be ephemeral when, in Sardino, the constitutionality of the Cuban Assets Control Regnlations was challenged. Dismissing the distinction, Judge Friendly said:

The due process clause speaks in terms not of taking but of deprivation; we find it hard to say there is no deprivation when a man is prevented both froin obtaining his property and from realizing any benefit froin it for a period of indefinite duration which may outrun his life. ${ }^{94}$

Nevertheless, the Judge thought that blocking was not suclı a deprivation as was proscribed by the Constitution. Apart froin being a legitimate way of compensating our own citizens, blocking could be justified on broader political grounds. It "does not follow," the Judge said,

... that in dealing with the property of an alien the United States must be blind to the acts of the country of which he is a national; the

91. Act of Oct. 16, 1964, Pub. L. No. 88-666, $\S 511(\mathrm{~b})$, 78 Stat. 1113 (codified at 22 U.S.C. $\$ \$ 1643$ et seq. (1970)).

92. S. REP. No. 701, 89th Cong., 1st Sess. 3 (1965).

93. Act of Oct. 19, 1965, $\$ 5,79$ Stat. 988, amending 22 U.S.C. $\$ 1643 \mathrm{j}$ (1964).

94. Sardino v. Federal Reserve Bank, 361 F.2d 106, 11 (2d Cir.), cert. denied, 385 U.S. 898 (1966). 
Constitution protects the alien from arbitrary action by our government but not from reasonable response to such action by his own .... We are not formally at war with Cuba but only in a technical sense are we at peace ... . The founders could not have meant to tie one of the nation's hands behind its back by requiring it to treat as a friend a country which has launched a campaign of subversion throughout the Western Hemisphere . . . . Hard currency is a weapon in the struggle between the free and the commumist worlds; it would be strange reading of the Constitution to regard it as demanding depletion of dollar resources for the benefit of a government seeking to create a base for activities inimical to our national welfare. The Supreme Court's approval of wartime seizure of assets of a non-eneiny alien "as a means of avoiding the use of the property to draw earnings or wealth out of this country to territory where it may more likely be used to assist the enemy than if it remains in the hands of this governinent," . . . is broad enough to justify the refusal of a license to Sardino. ${ }^{95}$

Distinctions of form-between the taking of title and other forms of deprivation-should not obscure the fact that in Sardino the court sanctioned the confiscation of private property. ${ }^{96}$ Moreover, while relying on cases such as Silesian-American Corp. v. Clark ${ }^{97}$ and Guessefeldt $v$. McGrath, ${ }^{98}$ Judge Friendly was clearly taking the war power a step beyond those cases, crossing the line between formal peace and war. Perhaps he should not have done so. On the other hand, much of the distance had already been traversed. ${ }^{90}$ A contrary

95. 361 F.2d at 111-12 (citations omitted).

96. The word "confiscation" is too often used without precision. Perhaps it means any uncompensated taking, by regulation, contract repudiation or expropriation, that is illegal. Analytically, this is merely equating the definition with a conclusion. To avoid this confusing usage, the word is used throughout this Article to mean any uncompensated deprivation of property, whether violative of law or not. Such usage, it is suggested, properly highlights the problem of values with which we are concerned.

97. 332 U.S. 469 (1947).

98. 342 U.S. 308 (1952).

99. In Ware v. Hylton, 3 U.S. ( 3 Dall.) 199 (1796), the Court appears to have affirmed the right of the government to confiscate all alien "enemy"-owned property, private as well as governmental, tangible or intangible, found within the United States, so that upon the termination of hostilities the property did not have to be restored to its former owners. By 1814 Chief Justice Marshall in Brown v. United States, 12 U.S. (8 Cranch) 110 (1814), was casting the right as applied to privately owned property in qualified terms. The right to confiscate private debts was not absolute since the alien owners' right thereto revived on the restoration of peace. Marshall then extended this principle to privately owned tangible personal property located in the country at the outbreak of hostilities, and distinguished such property from ship cargoes, which were subject to seizure as prize whether within or without the nation's territorial waters. Id. at 123. Ambiguously, however, he did admit of a power of "confiscation," but insisted that it is not a right conferred by international law as an incident of war, but a right which sovereign states could exercise in time of war. Hence the right to confiscate could not 
decision would have cast grave doubts, as the Judge was careful to point out, upon a long history of political department actions, including the

arise in the absence of congressional action. Id. at 125. Further compounding the ambiguity of the opinion, the Chief Justice confessed that it is a "harsh" right, not one which "modern usage would sanction," and one which tends to visit "obloquy" on those who exercise it. Id. at 123, 125. Against the background of this ambiguous judicial record, Borchard has pointed out that

the practice of the United States, as evidenced in Acts of Congress, treaties of the United States, Executive declarations and the uniform abstention from confiscation, notwithstanding occasional dicta of the courts as to the supposed privilege conferred by international law, sustains the view that there was in the United States, prior to 1914, an "established usage of exempting the property of non-resident enemies from confiscation." Borchard, Treatment of Enemy Private Property in the United States Before the World War, 22 AM. J. INT'L L. 636, 641 (1928).

At the same time, measures of sequestration and control for the duration of the war appear to have been taken. $6 \mathrm{G}$. HACKWORTH, Digest of INTERnational LAW 576 (1943).

Certainly Borchard's position conforms to the position taken by the State Department at the outbreak of World War I, see [1918] ForeIGN REI. U.S., Supp. II at 256, and to the fact that as originally enacted, the Trading with the Enemy Act, ch. 106, 40 Stat. 411 (1917), made the Alien Property Custodian only a "conservator" of private property seized, with a power of sale limited to prevent waste. Id. \& 12. (For a description of the Custodian's powers see United States v. Chemical Foundation, Inc., 272 U.S. 1, 11-13 (1926)).

With the amendment of the statute, Act of March 28, 1918, ch. 28, 40 Stat. 459, however, American practice changed. Rather than merely sequestering privately owned eneny property during wartime, the practice developed of retaining property even after hostilities had ceased for such purposes as the government saw fit. To the extent prior practice may be construed as an expression of the limits of national power under international law, this amendment certainly represented a departure from that law. Nevertheless, the courts were not disposed to impose the prior practice as a legal limitation on Congress. Thus, Judge Cardozo in Techt v. Hughes, 229 N.Y. 222, 244-45, 128 N.E. 185,192 (1920), acknowledged the "right" to retain alien property, but was of the opinion that it was a right "seldom brought into play in the practice of enlightened Nations." In an early post-World War I case, United States v. Chemical Foundation, Inc., 272 U.S. 1 (1926), the Court asserted the right as a constitutional matter in upholding a post-war sale for the benefit of American companies of German-owned chemical patents seized during the war. The patents were sold "to eliminate bostile alien interests and ... to advance chemical and allied industry in the United States." Id. at 6. Justice Frankfurter in Guessefeldt v. McGrath, 342 U.S. 308 (1952), thought that it was of little consequence whether the refusal to return property was "simply to secure claims of American citizens against Germany or was regarded as the rightful withholding of spoils of war." Id. at 314.

In Silesian-American Corp. v. Clark, 332 U.S. 469 (1947), the 1941 amendments to the Trading with the Enemy Act, Act of Dec. 18, 1941, ch. 593, $\$ 301,55$ Stat. 839, amending 12 U.S.C. $\$ 95 a$ (1940) (codified at 12 U.S.C. $\$ 95 a$ (1970)), designed to reach property nominally in the liands of "friendly" aliens but "tainted" by enemy control during any "period of national einergency" (not just formal war), were upheld as a proper exercise of the war power. The latter, it was said, permitted any "reasonable preparation for the storm of war," so that even a friendly alien could be subjected to a seizure designed to avoid the removal of "earnings or wealth out of this country to territory where it may more likely be used to assist the enemy than if it remains in the hands of this government." 332 U.S. at 476 . The "friendly alien's" only recourse was 
Litvinov Assignments. ${ }^{100}$ To have approved those Assignments and then denied the right to block or vest Cuban assets would have been to draw a totally unmanageable distinction between confiscations to facilitate the establishment of diplomatic relations with a foreign power and confiscations used in defense against a hostile power. Both the Litvimov Assignments and the Cuban blocking regulations, in short, give fair warning to the courts that in this matter of the confiscatory

to obtain compensation upon proving the absence of an enemy taint. Id. at 480 . Thus, even before Judge Friendly's decision, the practice of merely sequestering enemy-owned private property had been transformed into that of retaining (i.e., confiscating) it after hostilities had ended, while the property of even "friendly aliens" could be seized, subject to a right to sue for compensation, in preparation for the "storm of war." To the extent that international law up to World War I might be thought to have precluded such action, the courts were not prepared to interpose that law against Congress. Query: Was Sardino an extension at all?

100. 361 F.2d at 113. The Litvinov Assignments, negotiated as a consideration for American recognition of the Soviet government, assigned to the United States all assets located in this country to which the Soviet Union had claims under its various nationalization decrees. The assigned assets were to be used to pay American claims against the newly recognized Soviet government. The agreement is set forth in an exchange of letters between Maxim Litvinov, Soviet Coinmissar for Foreign Affairs, and President Franklin Roosevelt, reproduced in [1933] 2 FoREIGN REL. U.S. 812-14. In addition to the Litvinov Assignments, other peacetime vestings involved the seizure of certain Czechoslovakian assets some nine years after World War II, and the seizure of Bulgarian and Hungarian-owned assets well before the declaration of war against those powers. 361 F.2d at 113.

In the Litvinov Assignment cases, of course, the United States was simply claiming title to assets which the Soviet governinent had purported to confiscate. In blocking Cuban assets, the United States initiated the deprivation. This, however, is not a basis of distinction, as Judge Friendly recognized and as a comparison of United States v. Pink, 315 U.S. 203 (1942) and United States v. Belmont, 301 U.S. 324 (1937) makes rather plain. In Belmont the challenge to the Litvinov Assignments was proffered by a private American banking firm, with whom the assets in dispute had been deposited by the expropriated Russian company. As "stakeholder," the firm laid no claim to the assets in its own right, but challenged the Assignments on the ground that they violated the fifth anendment and that their enforcement would be tantamount to a judicial recognition of the Soviet decrees, contrary to the public policy of New York. The latter point was answered on grounds of act of state and the preclusive authority of the federal governinent over the conduct of foreign affairs. Id. at 331. The constitutional argument was dismissed, rather disingenuously, on the ground that the Constitution did not protect a Russian company from the confiscatory acts of the Russian governinent. Id. at 332. The Court quite ignored the fact that it was the United States government that was seeking the benefits of that confiscation through the aid of the American courts. In Pink, the constitutional objections were advanced by foreign creditors of the expropriated Russian firm. Justice Douglas was quite prepared to accept this fact as distinguishing Belmont, forthrightly acknowledging that he was dealing with a constitutional challenge to an action by the American government which, if given effect, would deny to private individuals their judicially recognized right to certain assets located in the United States. 315 U.S. at 226. If not the initiating expropriatory power, the United States in Pink was clearly the enforcing expropriatory state. 

tive, the American courts were not prepared to gainsay what the political departments thought necessary to be done.

But, surely, from the Cuban perspective, the necessities were no less compelling. At the time of Castro's rise to power nearly 40 percent of Cuba's sugar production was in American hands. The entire island was "enmeshed in a monetary economy dependent primarily upon the export of sugar."108 By its attacks on this American penetration of the Cuban economy and on the corrupt and repressive Batista regime which had long enjoyed official and private American support, the Castro revolution was at first hailed by most Cubans as promising true imdependence and the restoration of dignity and integrity to Cuban society. ${ }^{109}$

From this mitial point, it is not difficult to attribute to the final sweeping confiscatory measures of July, 1960 a necessity in the Cuban mind scarcely distinguishable from Judge Friendly's recital. From the Cuban perspective, that Government's efforts to deal with its central problem, vigorous only by necessity, had been met by retaliatory actions unequivocally threatening the very economic life of the island. The United States, because of its inability or unwillingness to control Cuban refugees, was a base for military actions against that government. The self-expressed American intent to fight communisin everywhere in Latin America presaged a cainpaign of subversion against the emerging forces of social and political change that were, to many Cubans, not only epitomized by their own revolution but given to their special charge. From the American perspective, Cuba's hostility toward the United States merited exempting the confiscation of Cuban property froin the literal strictures of the Constitution's guarantees; surely one must doubt any denial of Cuba's right to confiscate American property if the matter is but viewed from the Cuban perspective.

None of this, of course, is to suggest that Sardino was incorrectly decided or that Judge Friendly should have considered the Cuban perspective in reaching his judginent. He was not being asked to judge the legality of Cuba's decrees. The lesson is rather to highlight the distinctive task which faced the courts when they had to judge Cuba under international law. Either Sardino invoked a standard of national necessity not recognized by international law or, alternatively, the

108. Dawson \& Weston, Banco Nacional de Cuba v. Sabbatino: New Wine in Old Bottles, 31 U. Chr. L. Rev. 63, 71 (1963), quoting Tannenbaum, Ten Keys to Latin AMERICA 223 (1962).

109. For a careful analysis of the Cuban perspective see Dawson \& Weston, supra note 108 , at $67-73$. 
Sardino rationale can be fitted within the extant body of international custom. If these alternatives are self-evident, the decision in Citibank shows that their further implications were not so plain.

\section{B. Citibank and the Uses of International Law}

\section{Sardino as Contrary to International Law}

If Sardino cannot be squared with international law then it seems rather clear that both Cuba and the United States violated that law. Indeed, some of the more careless claims advanced on behalf of the non-discrimimatory, full, prompt and adequate compensation stand$\operatorname{ard}^{110}$ compel that conclusion. More seriously, if one embraces the view taken by the Second Circuit in both Sabbatino and Citibank that Cuba violated international law principally because its decree was in retaliation for the quota reduction, then a dual indictment seems inevitable.111 It will not do to suggest that Cuba was engaged in illegal retaliation while the United States was legally protecting the interests of its nationals. This is to suggest that a government may resort to confiscatory measures to protect its citizens' foreign investments but may not do so to protect the integrity of its entire economy. Certainly the inagnitude of Cuba's retaliation was not disproportionate to the injury which prompted its confiscatory action.

Moreover, the United States' right to defend its broader political interests was no less important to the decision in Sardino than the goal of obtaining redress for American citizens. Judge Friendly's reliance upon Silesian-American Corp. v. Clark ${ }^{112}$ is especially telling. In fact, he quite possibly felt obliged to invoke this broader rationale, simce the only line of judicial authority available dealt with the confiscatory power in the context of the larger necessities of war or its aftermath. Sardino would represent an extraordinary extension of these decisions if read as lending constitutional warrant to a confiscation of foreign-owned

110. See note 47 supra and accompanying text.

111. See Banco Nacional de Cuba v. Sabbatino, 307 F.2d 845, 859-68 (2d Cir. 1962), followed in Banco Nacional de Cuba v. Farr, 383 F.2d 166, 183-85 (2d Cir. 1967), cert. denied, 390 U.S. 956 (1968). See also Banco Nacional de Cuba v. First Nat'l City Bank, 478 F.2d 191, 194 (2d Cir. 1973) (the remand of Citibank). For differing views on the matter of retaliation in the international law of expropriations consult RESTATEMENT (Second) of the Foreign Relations LAW of tHe UNITEd States $\$ 200$ (1965); McNair, The Seizure of Property and Enterprises in Indonesia, 6 NETHERLANDS INT'L L. Rev. 218 (1959). But see Dawson \& Weston, supra note 108, at 91-96. Compare Domke, Indonesian Nationalization Measures Before Foreign Courts, 54 AM. J. INT'L L. 305 (1960), with Baade, Indonesian Nationalization Measures Before Foreign Courts -A Reply, 54 AM. J. INT'L L. 801 (1960).

112. 332 U.S. 469 (1947). See note 99 supra. 
property for the sole purpose of aiding the redress of private losses. It seems rather plain, in sum, that if Cuba violated international law because its confiscations were in retaliation for the quota reduction, the United States did likewise when it retaliated against Cuba for the latter's acts of hostility and subversion.

In this view of the matter, the difficulties implicit in the challenge to Sabbatino are considerable. Possibly the challengers were prepared to concede that Cuba did not violate international law-a doubtful matter at best. Even so, the possibility implies a reading of international law which invites a further set of complications yet to be discussed. If, on the other hand, the challengers were not prepared to grant this possibility, their decision is either an expression of total contempt for international law-an implicit statement that the United States courts enforce that law only against a foreign government, not their own -or an open invitation for sonreone to test the international legality of the Cuban Assets Control Regulations. And if the latter, then what of the constitutionality of these Regulations? Are the challengers prepared to reverse Sardino, overturn United States $v$. Pink ${ }^{113}$ and United States $v$. Belmont $t^{14}$ and cast doubt on the constitutionality of all the other peacetime vestings of foreign assets under the Trading with the Enemy Act? Or are they acknowledging that the constitutional precept niay not measure up to the high standards of international law? If the latter, what of the assumption that the rights of private property embodied in international law are rights deserving of strong judicial support? Or is the nuatter more properly viewed as a classic confrontation between principles and national necessity in which judicial abstention might well be recommended? Whether sucl1 abstention might be grounded upon the political question doctrine is a point considered later. Suffice it to suggest here that if the latter doctrine is inapposite, abstention still finds justification in Justice Harlan's comprehensive and non-positivistic view of law which recognizes that without a strict regard for the real limits that attend the judicial power, domestic courts can become breeders of contempt for international law.

\section{Sardino as Conforming to International Law}

There still remains, of course, the possibility that international law can be interpreted to accommodate the national welfare calculus articulated in Sardino. If this is the case, then the invitation to judge the legality of Cuba's actions is a task the dimensions of whicls deserve scrutiny.

113. 315 U.S. 203 (1941).

114. 301 U.S. 324 (1937). 
It was probably true that when Castro first came to power, many Americans (as well as Cubans) recognized that a fundamental change had to occur in the relationship between the two nations. Yet, even assuming arguendo that the confiscations prior to the sugar quota withdrawal were a necessary means to that end, what of the other elements in the pattern of Cuban behavior: Castro's declared ideology, his avowed determination to support revolution throughout the Hemisphere, the purchase of Soviet arms and the grant of Cuban territory as a base for Soviet military action? The issue is whether these factors supply a context in which the July 1960 confiscations had to be viewed as aggressive acts extending far beyond the necessities of the political and economic independence acknowledged by the controlling Sardino criteria. This is certamly the American view of the matter.

On the other hand, while Cuba's actions could not be divorced from Cuban ideology, the ideological component did not automatically deprive those actions of legitimacy if tested by a neutral standard. Nor did it mean that the confiscations, even if part of a larger pattern of belligerence toward the United States and of hemispheric subversion, could not stand on their own merits. Were they measures necessitated by the very strength and determination of the entrenched American interests, freedom from which was their legitimating object? At bottom, it is the choice between these competing characterizations that is the critical question for any American court bent upon judging Cuba according to an international standard which conforms to the standards it would employ in judging its own government under the Constitution.

To define the issue in these terms, however, is not enough. The matter of perspective is perhaps more important. If there is to be judgment accordimg to international law, the contending national perspectives must, perforce, be subjected to some international standard defining what combimation of circumstances signals that national necessity of which the rule is an acknowledgment. To judge Cuba's acts according to the American characterization of the case, no less than to adopt a Cuban characterization, is to abandon all pretense at decision based upon international law. This means, of course, that the courts must abjure the guidance of their own pohtical departments. Except as they may draw upon the views of some international political authority or upon a broader international political consensus, they must depend largely upon their own resources of perception and evaluation. The task is a formidable one.

If the legitimuacy of Cuba's asserted claim of acting in defense of its own sovereignty is to be judged fairly, then judgment requires an 
understanding of Cuba's historical relationship with the United Statesa sense of the cumulative impact on the Cuban psyche of over fifty years of intercourse with American institutions and culture and an awareness of the actual American economic and political penetration of Cuban society. If the court is to measure the proportionality of Cuba's response to the forces arrayed against it, then it must have some sense of how much those forces were rationally to be feared. To judge is to assess the threat implicit in the quota termination, the OAS sanctions, the lostile acts of Cuban refugees and the failure of American authorities to prosecute thein, and even the Bay of Pigs adventure. To judge, in short, is to differentiate between rational defensive behavior and hostile actions serving principally to secure Castro's domestic political power or to satisfy the aggressive instincts of his Communist ideology. It is a formidable task, indeed, and one in which there is no room for careless indictments of arbitrariness and discrimination.

Finally, to define the judicial task in these terms compels recognition of the reciprocal nature of the problem. Any judgment validatimg Cuba's actions under the controlling Sardino rationale carries with it a strong and perhaps decisive implication that the countermeasures by the United States were excessive and, froin an international perspective, of doubtful legality. In other words, the controlling characterization of the foreign government's action may very well depend upon a prior characterization of the American action. A decision validating the foreign government's act inay be only one small step removed froin a decision invalidating the American act. Certainly, a decision of validity would be an open invitation to challenge the international legality of the latter, notwithstanding that they may have met constitutional standards applied according to an American characterization of the conflict.

Once again, abstention would seem to be an expedient of considerable merit. The setting is a limited one. The importance of the conflict and the climate of hostihity which attended it-its proximity to a "state of war"-had caused the United States to confiscate the properties of foreign citizens. It was a setting in which any judgment invalidating those actions would, by historical evidence, have impaired the political departments' ability to deal with conflicts which could have too easily escalated into war. If, in this setting, the foreign government's actions were to be judged objectively from a perspective which presented a fair possibility of validating those actions, the inherently complex and subtle nature of the question juxtaposed with the impingement of the 
decision upon an important exercise of foreign policy would seem to prescribe a classic occasion for abstention.

Even more broadly, the case illustrates the important part that a rule of judicial abstention can play in promoting a more viable international order. The question is whether American courts, having validated their own government's political acts under their own Constitution as interpreted from a national perspective, should be called upon to invoke an international perspective which might well invalidate those same actions. Where judgment is attended with some uncertainty and the consequences for the national interest are large, the inescapable fact is that domestic courts generally, if compelled to decide, are inore likely than not to decide at the expense of a truly international perspective. Their authority is rooted in the nation. Subtly, lowever anxious they are to einploy a broader perspective, such courts, unless permitted to escape judgment, can rarely escape giving effect to the felt needs, the political perceptions and the sense of outrage which, in the nature of the case, must attend the acts being judged. The very thought of the Supreme Court of the United States announcing that Cuba acted more in self-defense against American aggressiveness than in pursuit of its own subversive designs would no doubt sliock nany. Yet the point is plain. If the Supreme Court cannot in fact say such things, it has no business pretending that its judgments would advance the cause of international law. It can only parochialize that law and, in the inatter of expropriations, polarize it as well.

\section{Citibank and the Political Question Doctrine}

\section{Introduction}

It remains to test these observed implications of the Citibank case against the historical uses of the "political question" doctrine. Initially, it is worth observing that The Paquete Habana, ${ }^{115}$ often cited as the Court's foremost affirmation of allegiance to customary international law, ${ }^{110}$ is in fact persuasive authority for the suggestion that the Court in Citibank should have abstained from applying that law.

In The Paquete Habana the Court declared the Navy's seizure of private fishing vessels during the Spanish-American War invalid as an offense against international law only after scrutinizing the record and

115. 175 U.S. 677 (1900).

116. See, e.g., Sabbatino, 376 U.S. at 423; Skirotes v. Florida, 313 U.S. 69, 73 (1941); Kansas v. Colorado, 206 U.S. 46, 97 (1907); District of Columbia v. International Distrib. Corp., 331 F.2d 817, 320 n.4 (D.C. Cir. 1964). 
finding a total absence of a "treaty or other public act of the Government" in relation to the matter. ${ }^{117}$ Indeed, the Court took care to read into the applicable Presidential orders an implied absence of authorization for the seizures, a point that much exercised the dissent. ${ }^{118}$ It also mvoked the aid of Chief Justice Marshall's decision in Brown v. United States. ${ }^{119}$ Extending that decision to the case of prize, the Court in Paquete Habana held that the absence of any congressional authorization for the seizure of the Cuban fishing vessels and Chief Justice Marshall's msistence that such an authorization was required combined to furnish the ultimate justification for invoking international law against the Navy. ${ }^{120}$ It seems beyond doubt, in other words, that had the Court been confronted with clear presidential or congressional authorizations for the seizures, it would not have interposed customary international law to imvalidate the Navy's actions. International law would have given way to policy.

This reading, of course, squares with the refusal of the Court in the later Trading with the Enemy Act cases cited in Sardino to hold Congress to the international law reflected in the uniform practice of the United States prior to $1914 .^{121}$ Indeed, any suggestion that Paquete Habana would warrant interposing customary international law against a congressionally authorized wartime seizure would mean that that case liad been overruled by these later decisions. But if not overruled, any effort to limit its implied sanction to the precise wartime context of the case would inean reversing Sardino and striking down the Cuban Assets Control Regulations on international law grounds. Thus, unless prepared to take this latter step, the Court, if desirous of applying international law evenhandedly, might well have refused to imterpose international law against the acts of the Cuban government in Citibank and cited Paquete Habana as controlling authority.

More importantly, the several opinions in Paquete Habana will readily suggest to the discerning reader how difficult it may sometimes be to decide when the judicial institution should subject the nation to the consensual mandates of the international community. The difficulty inheres in international law itself. By the very fact that international law purports to limit the unilateral use of national power in the international arena-to limit sovereignty-that law also impliedly,

117. 175 U.S. at 711.

118. Id. at 716-17 (Fuller, J., dissenting).

119. 12 U.S. (8 Cranch) 109 (1814).

120. 175 U.S. at 710-11.

121. See note 99 supra. 
if not expressly, sanctions other unilateral exercises of power. International law affirms, not denies, the existence of sovereignty. The problem is always, therefore, one of defining the power and the limits of its exercise. At some point when the definitional task becomes sufficiently uncertain and the consequences for the nation sufficiently momentous, domestic courts must, in loyalty to the basic sources of their own authority, either abstain from judging altogether or confirm their own political departments in the power sought. Paquete Habana is simply an example of the latter course. As such, it invites further inquiry into the boundaries of that region where domestic courts must issue the necessary concession, whether by affirmation or abstention. We turn to the latter.

\section{Of Analytic Modes}

Some years ago, one eminent authority suggested that the leading political question cases in the foreign affairs area were to be explained by the juncture of the Constitution's textual commitment of foreign policy to the political departments and the imperative of unity in national expressions on sucl matters. ${ }^{122}$ But this formulation would seem to prove too much.

It is doubtful that every question whicl is susceptible of principled resolution, but which happens to touch foreign policy, is constitutionally withheld froin the courts. ${ }^{123}$ If, on the other hand, wliat is intended is a more selective search for a particular textual reference, the test

122. Weston, Political Questions, 38 HARv. L. REv. 296, 318-19 (1925).

123. To find a commitment to the political departments that implies a textual denial of judicial authority on these questions, Weston avers that the "relevant provisions of the Constitution ... divide the power of administering foreign affairs, to the complete exclusion of the judiciary" (emphasis added). Id. at 319 n.89. It is difficult to disprove this proposition by reference to existing case law. That courts frequently decide the merits of questions touching foreign policy may cast doubt upon it. But Weston can explain this by the second prong of his test-the absence of a need for a unity of expression. Where, in the cases he reviews, one observes the courts declining to adjudicate the merits, Weston can cite the presence of both elements of his test. That the latter prong is sufficient, and the former therefore immaterial and of doubtful validity, simply cannot be proved. Nevertheless, as Henkin has pointed out, the Court has many times decided constitutional and other legal challenges to foreign policy decisions on their merits without resort to the political question doctrine. L. HENEIN, ForeIGN AFFaIRS AND THE Constrtution 213 (1972). This would seem a sufficient response to Professor Weston, even granting that he was apparently prepared to make an exception for constitutional challenges. See Weston, supra note 122, at 329-30.

Henkin, however, goes further and argues that there is "apparently no foreign affairs case in which the Supreme Court ordained or approved judicial abstention from Constitutional review or from deciding some other question that might have led to a different result." L. HENKIN, supra, at 213. This observation as applied to constitutional 
can rarely avoid an interpretive question: does a specific grant to the President or Congress of the power to decide carry with it an implied ban upon the power of the judiciary to review exercises of that power? If the theory would confine the whole of this interpretive task to the narrow inodes of conventional textual exegesis-the parsing of words and the search for meaning from context and framers' intent-then, as others have fully demonstrated, the theory simply does not explain the cases. $^{124}$

To add to the test the imperative of national umity only serves to shift the whole explanation away from a textual commitment and toward the functional attributes of the doctrine. This, in turn, only invites further inquiry into when that imperative is deemed to exist. Undoubtedly it has something to do with the "unusual need for unquestioning adherence to a political decision already inade" or with the "potentiality of embarrassment from multifarious pronouncements by various departments on one question." "125 But these Baker v. Carr formulations likewise are not criteria for application of the doctrine. They are only statements of function that steer inquiry along relevant lines but do not provide a measure of when the need is "unusual" or when the potential "embarrassment" is to be avoided. And it is not function but standards that are of concern here.

Nevertheless, the textual commitments theory does seen to reflect a search for standards. If it would permit what one obviously exasper-

review is arguably subject to qualification in light of United States v. Pink, 315 U.S. 203 (1942), and cases involving the expulsion of aliens, Harisiades v. Shaughnessy, 342 U.S. 580 (1952) and Galvan v. Press, 347 U.S. 522 (1954). See Scharpf, Judicial Review and the Political Question: A Functional Analysis, 75 YALE L.J. 517, 542 (1966). But see McDougal \& Lans, Treaties and Congressional-Executive or Presidential Agreement; Interchangeable Instruments of National Policy in McDougaI \& Associates, Studies IN WORLd PUBlic ORder 404 (1945). Certainly the lower courts have not refused to apply the political question doctrine to constitutional challenges. See United States v. New York Trust Co., 75 F. Supp. 583 (S.D.N.Y. 1946); Steingut v. Guaranty Trust Co., 58 F. Supp. 623 (S.D.N.Y. 1944), aff'd, 161 F.2d 571 (2d Cir. 1947). For a discussion of this point as it relates to non-constitutional cases, see note 146 infra.

124. Scharpf, supra note 123, at 543-48.

125. Baker v. Carr, 369 U.S. 186, 217 (1962). In full, Baker v. Carr laid down the following tests for a "political question": "a textually demonstrable constitutional commitment of the issue to a coordinate political department; or a lack of judicially discoverable and manageable standards for resolving it; or the impossibility of deciding without an initial policy determination of a kind clearly for nonjudicial discretion; or the impossibility of a court's undertaking independent resolution without expressing lack of the respect due coordinate branches of government; or an unusual need for unquestioning adherence to a political decision already inade; or the potentiality of embarrassinent from multifarious pronouncements by various departments on one question." Id. 
ated judge intimated-a "license to construe the sense of the Constitutional framework"126 - then perhaps it should be read more as a means of securing adherence to a certain decisional inodality than a command to search for precise textual guidance. Perhaps it should be read only as proscribing resort to broadscale notions of judicial prudence and discretion, not as iguoring the central question: namely, how far inay courts go without violating that tradition in which the consensual nature of law is not merely recognized but celebrated as the bulwark of a free society? If there is something of prudence in this, it is not the prudence of a wise discretion but of a more compelling concern for judicial legitimacy derived largely from the experience of history. It is submitted that, by this reading, what ensues conforins to the theory. ${ }^{127}$ And by this reading, Citibank and Sabbatino did indeed present the Court with a political question. ${ }^{128}$

\section{Of Subject Matter}

The first element apparent in the cases is the nature of the subject matter. Time and time again the Court has shown a concern for the enormity of the consequences that might attend its decision, a sense of the inherent largeness of the issue. Factual context, the explanations proffered, even the tenor of the rhetoric make sheer folly of any effort to exclude this animating sensitivity from the decisions.

126. Massachusetts v. Laird, 451 F.2d 26, 32 (1st Cir. 1971) (Coffin, J.).

127. With some trepidation in view of the late Professor Bickel's celebrated dissent from his views, Bickel, Foreword: The Passive Virtues, 75 Harv. L. REv. 40, 43 et seq. (1961), and my own obvious employment of the elements in the Bickelian formulation, I nevertheless suggest that the mode offered here is in keeping with Professor Wechsler's response to other patently more prudential views of the doctrine:

Difficult as it may be to make that judgment wisely, whatever factors may be rightly weighed in situations where the answer is not clear, what is involved is in itself an act of constitutional interpretation, to be made and judged by standards that should govern the interpretive process generally. That, I submit, is toto caelo different from a broad discretion to abstain or intervene. Wechsler, Toward Neutral Principles of Constitutional Law, 73 HARv. L. REv. 1,9 (1959).

128. A certain operational distinction between act of state and political question should be noted. In the political question cases the courts abstamed from judging particular acts of the American government in order to protect the integrity of those acts. Having abstained on the merits they then either abstained from all use of the judicial power or proceeded to use their power affirmatively, adopting the political department's actions as the controlling rule for their decision. In the act of state cases, however, it is the acts of a foreign government that are being judged even though it may be the policies of the American government that are being protected. It is these latter that may lend to the case the character of a political question, but not being in issue betwcen the parties they cannot supply the controlling rule of decision. Thus, like the political question doctrine, the act of state doctrine may mandate abstention from judgment on the merits, but unlike political question it does not mandate adoption of the policies of 
In the most influential of the early cases, Foster \& Elam v. Neilson, ${ }^{128}$ Chief Justice Marshall declined to determine whether, under the controlling treaties, West Florida was included in the 1803 Louisiana Purchase. The area had long been claimed by the United States. The President and Congress had authorized its occupation. It had been used to form the Alabama Territory in 1817. Alabama had been admitted to the Union in 1819. The Chief Justice's recitation of all this nuakes plain how far he was nroved to his decision by the enormous consequences that a contrary judicial decision in 1829 would have had upon the internal order of the nation. It was unthinkable that the courts of the United States, under the guise of a superior interpretation of a treaty, would risk effectively invalidating all of the political departnients' acts of governance in the period 1803-1819. ${ }^{130}$

A decade later, in Williams $v$. Suffolk Insurance Co., ${ }^{181}$ the Court extended Neilson to a claim by a foreign sovereign to foreign territory. The judiciary, it said, was bound by the Executive's determination that "Buenos Ayres" did not have a valid international claim to sovereignty over the Falkland Islands. Neilson and Suffolk were then followed in a case involving a United States claim to foreign territory. In Jones $v$. United States, the question was whether one of the Guano Islands was territory "appertaining to the United States" for purposes of criminal jurisdiction. ${ }^{132}$

Arguably, of course, any judicial action that could impair the longaccepted territorial definition of the United States (Neilson), or the claim of the United States to control foreign territory (Jones), is an action the inherent momentousness of which exceeds anything that might be entailed in a conflict with a foreign government short of war. And while in Suffolk the United States was not claiming sovereign riglits over the Falkland Islands, the Executive denial of the foreign claim was issued in the context of a quarrel over seal hunting rights which culminated in the Navy's expulsion of Argentinian officials from the islands. The Court was plainly sensitive to this context. ${ }^{138}$

the American government as the controlling rule of decision. Act of state is operationally distinct, even though its use may be guided by the criteria of a political question. The implications of this distinction are elaborated at note 251 infra.

129. 27 U.S. (2 Pet.) 108 (1829).

130. Id. at 114, 123. For a contrary view of Neilson, see Dickinson, The Law of Nations as National Law: "Political Questions," 104 U. PA. L. Rev. 451, 454 (1956). 131. 38 U.S. (13 Pet.) 415 (1839).

132. 137 U.S. 202, 209 (1890).

133. The Executive's denial of Buenos Ayres' claim was conclusive, for otherwise, the Court said, one department might consider a "foreign island or country . . . at peace with the United States; whilst the other would consider it in a state of war." No "well 
Nevertheless, the Court has not read these precedents so narrowly. On the contrary, as the recognition cases show, they have been read as establishing that all questions of sovereignty over territory, whether involving an American claim or not, are political questions. Thus, in the early decisions such as Rose v. Himely, ${ }^{134}$ and Gelston v. Hoyt, ${ }^{135}$ principles of international law were held to govern when a party was to be recognized as de facto or de jure the government of a foreign country. These principles were, however, "addressed to sovereigns, not to courts," as Chief Justice Marshall put it. ${ }^{136}$ Then in Oetjen v. Central Leather Co ${ }^{137}$ and Pearcy v. Stranahan, ${ }^{138}$ the Court separated the issue from international law, treating it as a question of policy ${ }^{139}$ belonging exclusively to the Executive, and relymg explicitly for this upon the Neilson, Suffolk and Jones line of decisions.

The leading case in another instructive line of decisions is Doe $v$. Braden, ${ }^{140}$ which established that the courts lacked authority to inquire into a foreign official's treaty-1naking power. ${ }^{141}$ Such inquiries,

regulated government" would, according to the Court, sanction a "principle so unwise, and so destructive of national character." 38 U.S. (13 Pet.) at 420 . This, of course, is an example of the Court relying upon the need for unity in national expressions. But the need arises out of a special limiting context, rife with possibilities for armed conflict.

134. 8 U.S. (4 Cranch) 241 (1808).

135. 16 U.S. (3 Wheat.) 246 (1818).

136. 8 U.S. (4 Cranch) at 272.

137. 246 U.S. 297 (1918).

138. 205 U.S. 257 (1907).

139. See Oetjen, 246 U.S. at 302; Pearcy, 205 U.S. at 265. This position accords with that taken by at least one Legal Adviser to the State Department, see "Russia v. Poland," Memorandum from Green Hackworth, Legal Adviser, Dep't of State, to Secretary of State Cordell Hull, Jan. 29, 1944, reproduced in 2 M. WhITEMaN, supra note 47 , at 5-6, and on one occasion by the Secretary General of the United Nations, Memorandum by Trygve Lie, Secretary General, United Nations, Mar. 8, 1950, U.N. Doc. S/1466.

140. 57 U.S. (16 How.) 635 (1853).

141. Application of the rule in Doe v. Braden is found in a much earlier incident in which the authority of the foreign official being challenged was not his treaty-making authority, but his authority to confiscate American-owned property. In 1794 the French government requested Secretary of State Edmund Randolph to stop an action in which the Governor of Guadeloupe was arrested for his allegedly wrongful seizure of plaintiff's vessel while Governor. The Governor was in Philadelphia at the time of arrest awaiting ship to France, having been captured by the British and released on parole. In advising the Secretary, Attorney General William Bradford concluded that the defendant had no "legal claim to be privileged from arrest." As to "his suability," the Governor was, the Attorney General continued, "on a footing with any other foreigner (not a public minister) who comes within the jurisdiction of our courts." But, Bradford went on to note, if the act of which plaintiff complains

... is admitted to have been an official act, done by the defendant by virtue, or under color, of the powers vested in him as governor, that it will of itself be a sufficient answer to the plaintiff's action; that the defendant 
Chief Justice Taney thought, would make it "impossible for the executive department ... to conduct our foreign relations with any advantage." ${ }^{142}$ The rule of Doe v. Braden has been given a more contemporary application in such cases as Terlinden $v$. Ames, ${ }^{143}$ involving the authority of the German Empire to carry out a treaty made with Prussia, and Clark v. Allen, ${ }^{144}$ which dealt with the capacity of Germany to carry out a treaty on inheritance rights during the allied occupation. ${ }^{145}$

ought not to answer in our courts for any mere irregularity in the exercise of his powers; and that the extent of his authority can, with propriety or convenience, be determined only by the constituted authorities of his own nation. 1 OP. ATT'Y GEN. 45, 46 (1794).

Not being a case for a grant of sovereign immunity, it was not a case, so the Attorney General advised, for ". . . the interposition of the government." Nevertheless, he was of the view that if the quoted "principle [were] ... made evident to the judge, he [would] discharge the defendant from his bail, and the plaintiff probably [would] prosecute his suit no further."

Plainly, the Attorney General understood the difference between act of state and sovereign immunity, and was sensitive to a difference in the role of the Executive under each. See discussion at note 200 infra. Moreover, the close parallel between this action and the constitutionally footed rule in Doe v. Braden, together with Justice White's admission in Sabbatino that any inquiry into the legality of a foreign act under the organic law of the foreign state may be proscribed by the act of state doctrine, 376 U.S. at 470 71 (White, J., dissenting), casts an intriguing historical cloud over his reluctance to admit a constitutional footing for act of state.

142. 57 U.S. (16 How.) at 657.

143. 184 U.S. 270 (1902).

144. 331 U.S. 503 (1947).

145. In Terlinden the Court, citing Chief Justice Taney's opinion in Doe v. Braden, 57 U.S. (16 How.) 635 (1853), held that the question of whether an 1852 extradition treaty with Prussia had been terminated by Prussia's subsequent absorption into the German Empire, being a "question of whether power remains in a foreign State to carry out its treaty obligations ..., was, in its nature political and not judicial." 184 U.S. at 288. Notably, however, the Court offered this conclusion only after a considerable discussion apparently intended to satisfy itself that the State Department's assertion of organic authority in the new imperial government to carry out Prussia's obligations was at least a supportable conclusion. This approach is not without its theoretical significance, as we shall observe. In Clark, a 1923 treaty with Germany relating to inheritance rights was upheld against a claim that it was terminated by Germany's defeat and the subsequent allied occupation. Relying inter alia upon Terlinden, the contention was seen by Justice Douglas as posing a political question, answered, in turn, by the absence of any showing that the political departments considered Germany's collapse inconsistent with the maintenance and enforcement of the Treaty. 331 U.S. at 514. Justice Douglas was quite prepared to treat the problem as one mvolving the termination of a treaty by reason of supervening war; to this end he quoted at length from Judge Cardozo in Techt v. Hughes, 229 N.Y. 222, 128 N.E. 185 (1924), and also cited Society for the Propagation of the Gospel v. New Haven, 21 U.S. (8 Wheat.) 464 (1823). But unlike these latter cases, Justices Douglas' opinion undertook no independent inquiry into the coiniatibility of the treaty provisions with the interests of the nation either at war or under the succeeding occupational regime. He declared himself prepared to consider the treaty terminated only if the Executive or Congress had "formulated a national policy quite incon- 
All of these decisions exhibit a common thread: whom was the United States to consider sovereign in a community of sovereign states, or to what people or territory were the attributes of sovereignty to be accorded, or what credence was the United States to give those who asserted a right to exercise sovereign authority? By its decisions on these issues the Government establishes the framework and sets the controlling climate for all the discrete acts of policy which it may later pursue. They are questions central to the very existence of policy and the ability of the pohitical departments to give expression to the national interest. They are questions foreclosed to the judiciary because they are central to the fixing of a basic relationship between the Umited States and a foreign government, and not because the Court has found itself without a basis im international precept for gam-saying the political departments. The Court's decisions thus represent a clear-cut exercise in extraordinary judicial abstention. ${ }^{146}$

sistent with the enforcement of a treaty in whole or in part." Clark v. Allen, 331 U.S. $503,509-10$ (1947). In light of this, it would seem preferable to read the case as dealing more with the capacity or status of the treaty partner to carry out its obligations, along the lines of Doe v. Braden and Terlinden, than as strictly a termination by war case.

146. Professor Henkin in his recent book has rendered a singular service in coming to grips with a problem in the interpretation of these cases which has too long been ignored. See L. HenkIN, supra note 123, at 213. He offered a distinction. On one hand, Henkin suggested, there is the "constitutionally significant" use of political question as an "ordinance of extraordinary judicial abstention", a use for which he professed to find no example among the foreign relations decisions of the Supreme Court. On the other hand, there are cases where a political department decision is challenged and the Court uses political question to mean that the question is "within the powers granted by the Constitution to the political branches to decide." Id. If in the latter type case, Henkin observed, the political department's actions do not violate or are not subject to any relevant constitutional limitations, the Court proceeds "to give effect to what the political branches have done." Id. at 213-14. In this latter category he included Suffolk and Jones, and, by negative implication, Neilson as well as Kennett v. Chambers, 55 U.S. (14 How.) 38 (1852). See L. Henkin, supra note 123, at 450-51 n.27. The use of the political question label in these cases is, if I understand Professor Henkin correctly, at best confusing. At worst, Henkin appeared to suggest, it mistakenly implies a constitutionally mandated act of judicial abstention when actually all that the court did was enforce what the political departments had "done because they had political authority under the Constitution to do it." Id. at 213. The case is no different than when a court refuses to examine the wisdom of any political act so long as that act is within the constitutional powers of the political departments.

Obviously, a distinction exists between abstention under the political question doctrine and a judicial refusal to judge the wisdoin of political department actions found to be within the latter's constitutional purview. I only question the effort to place the leading forcign affairs decisions into this latter category.

Initially, I suggest, the effort rests upon a failure to recognize that a refusal to judge the "wisdom" of a political department decision and a refusal to judge a "political question" are both derived from a constitutional definition of the scope of the judicial 
In hight of the events of 1959-1963 it is not difficult to fit the policy consequences of a judgment regarding Cuba's actions within the

power. The relevant question in ascertaining the scope of that power as defined by the political question doctrine is, therefore, whether the elements of a political question exist, not whether a court characterizes its decision in that fashion. Nowhere does Professor Henkin offer his own benchmarks by which to test whether the leading foreign affairs cases contain the requisite elements of a political question. Conversely, he appears to ignore the fact that neither a court's affirmation of the power of the political departments to act nor its refusal to judge the wisdoin of that act eliminates the possibility that it was responding to the constitutional definition of its power inplicit in the political question doctrine. Such a decision may indeed represent an act of extraordinary judicial abstention, depending upon the elements that prompted the decision. See, for example, the discussion of The Paquete Habana, notes 115-20 supra and accompanying text.

Beyond this, the fact that a court which employs the political question label may then turn around to use its power affirmatively to enforce a political decision on the point is not in the least inconsistent with the use of the political question doctrine as an ordinance of extraordinary judicial abstention. The abstention mandated by the political question doctrine is not necessarily an abstention from all use of the judicial power, but only from an independent judgment on the merits. Given the functional attributes of that doctrine (e.g., Weston's unity of expression; see note 123 supra), the observed enforcement of the political department's decision may represent only what is required to carry out the function which necessitated abstention from a judgment on the merits in the first place.

The international law cases cited by Henkin illustrate the point. In none of these instances was there a dearth of rules that might have been employed by the Court to decide the merits of the case in the fashion that courts usually decide such questions. Apart from the decision to abstain, in other words, the substantive issue to be decided was for the courts. It was not one given exclusively to the wisdom of the political departments. Yet one may, of course, choose to characterize what the Court did in positive terms: it affirmed the power of the political departments to decide. One can also take the Court at face value and characterize what it did in negative terms: it declared the courts powerless to decide. Choosing one characterization rather than the other does not aid understanding.

What cannot be doubted is that the Court did not judge the merits of a question it might have judged-in any sense of the word, it abstained. If that abstention was predicated upon elements definitive of the constitutional proscription called political question, then that abstention was, in any sense that is useful, the response to a constitutional ordinance. This is wholly different from a case in which the substantive issue, quite apart from the elements of a political question, could not be decided by a court in any event, i.e., a case involving questions which were political without regard to the special context out of which they reached the court. In those instances the court simply proceeds to the one question within its competence to answer: did the political departments have the constitutional authority to do what they did?

A contrary view is predicated upon some extraordinary conclusions. To say that in neither Neilson nor Suffolk was the Court engaged in an act of extraordinary judicial abstention is to imply that neither the language of a treaty nor customary international law can ever supply a rule of decision for an American court. If the point is that the Court should not have abstained, that is inerely a quarrel over the rcquisite elements of a political question as a constitutional ordinance; the only responsive line of argument would be to tender an alternative definition of what those elements might properly be, recognizing that these seminal cases hold to the contrary. 
controlling sense of these cases. Having earlier welcomed the Castro revolution and recognized the Castro government, the United States, for the reasons enumerated by Judge Friendly, was engaged during this period in a rather fundamental realignment of its basic relationship with Cuba. The cessation of diplomatic relations, the quota reduction, aid to Cuban refugees, mitiatives in the OAS, the Bay of Pigs adventure and ultimately the blocking of Cuban-owned assets in this country were all part of the change. One could scarcely conceive of a sequence of acts, short of war, having a more encompassing impact on the structure of the political relationship between the two countries. And this was their purpose. Without mucli doubt; since any objective imquiry under the Sardino formula raised the possibility of validating Cuba's decrees and thereby opening the entire course of American policy to a charge of international aggression, that inquiry entailed a subject whose momentousness signalled a potential political question. Even if the courts were certain of invalidating those decrees, it would appear that the implications of the decision for the American blocking of Cuban assets would also have come within their ambit. ${ }^{147}$

147. Judge Friendly's characterization of the Cuban-American relationship as a state of near war evokes certain of the war powers cases in support of abstention in these circumstances. When asked to decide whether a condition of war exists between this nation and any foreign power in the international legal sense, as in the case of prize, the Court has uniformly followed the latest utterance of the political departments, whether in the form of declarations, treaties, joint resolutions or other competent acts. Herrera v. United States, 222 U.S. 558 (1912); Ribas y Hijo v. United States, 194 U.S. 315 (1904); The Buena Ventura, 175 U.S. 384 (1899); The Brig Amy Warwick (Prize Cases), 67 U.S. (2 Black) 635, 688-90 (1862). In deciding upon the constitutionality of a purported exercise of the war powers in the uncertain period between the end of fighting and the formal peace, however, the Court appears to have drawn something of a distinction. For certain purposes such as the continuance of wartime prohibition, Hamilton v. Kentucky Distilleries \& Warehouse Co., 251 U.S. 146 (1919), immediate post-war rent controls, Woods v. Cloyd W. Miller Co., 333 U.S. 138 (1948), and the post-war reorganization of the wartime price control agencies, Fleming v. Mohawk Wrecking \& Lumber Co., 331 U.S. 111 (1947), the question of the constitutional power to act was not answerable solely by reference to the existence of a formal state of war in the international legal sense; hence, it was answerable by the courts. Yet for purposes of seizing "enemy alien" property, Commercial Trust Co. v. Miller, 262 U.S. 51, 57 (1923), or deporting an enemy alien, Ludecke v. Watkins, 335 U.S. 160 (1948), during this interim period, the judicial power seems to have been treated differently. In the latter case Justice Frankfurter appears to have held that the Court was bound to concede to Congress the power to grant (and to the President, the power to exercise) a deportation authority until the state of war had been terminated, and that "whatever the mode" that "termination [was] a political act." Id. at 168-69. This, the Justice said, was because a contrary holding would suggest that "the unconditional surrender" and disintegration of the Nazi regime "have left Germany without a government capable of negotiating a treaty of peace"-a clear echo of the Doe v. Braden principle as elaborated in Terlinden v. Ames and Clark v. Allen. Nor did the courts have, accord- 
Buttressing all of this are the cases dealing with the effect of legislation upon a subsisting treaty as a source of domestic law. In spite of the suggestion by John Jay in the Federalist Papers that treaties were immune under the supremacy clause from unilateral legislative nullification, ${ }^{148}$ the contrary is by now axiomatic. Inconsistency being unavoidable, a later-enacted statute supersedes a treaty as the controlling rule of decision for the courts even when the result is a breach by the Umited States of its solemn international obligations. It is true that at times the Court seens to have relied upon the supremacy clause for this conclusion; the mention of both treaties and statutes in the clause created, it was said, an hierarchical equality compelling resort to the later in time. ${ }^{149}$ But the rule is now firmly, and properly, ${ }^{150}$ rooted in the broader constitutional relationship between the judiciary and the other departments of the government. The Chinese Exclusion Case ${ }^{151}$ supplies the controlling expression. The Court characterized the power

ing to the Justice, the "technical competence" or "official responsibility" to question the President's "political judgment" that enemy aliens still retain their "potency for mischief during the period of confusion and conflict" which follows active hostilities. Id. at 170 . Whether these war powers cases can be persuasively reconciled or not, they do suggest a measurably greater judicial sensitivity to the political character of the question if a decision appears to have a wider significance for foreign relations or for the Government's ability to meet the special demands that the aftermath of war imposes upon the nation. In this view, Ludecke marks a line, however uncertain, between decisions confined to matters largely domestic and peripheral to the demands of war and its aftermath and decisions that tend to affect the nation's immediate post-war international legal relationships or have a discernible impact on the conduct of external affairs in that uncertain time. If this is so, then it would be incongruous for the Court to invoke a rule of customary international law against a foreign government which, if applied evenhandedly against the American government, would bar any exercise of similar powers in situations of ncar-war.

148. Speaking specifically about the supremacy clause, John Jay had the following to say in The Federalist:

They who make laws may, without doubt, amend or repeal them; and it will not be disputed that they who make treaties may alter or cancel them; but still let us not forget that treatics are made, not by only one of the contracting parties, but by both; and consequently, that as the consent of both was essential to their formation at first, so must it ever afterwards be to alter or cancel them. The proposed Constitution, therefore, has not in the least extended the obligation of treaties. They are just as binding, and just as far beyond the lawful reach of legislative acts now, as they will be at any future period, or under any form of government. THE FEDERALIST No. 64, at 405 (H. Lodge ed. 1888) (J. Jay).

149. Whitney v. Robertson, 124 U.S. 190 (1888); Edye v. Robertson (The Head Money Cases), 112 U.S. 580, 598-99 (1884).

150. The supremacy clause refers to the Constitution along with federal laws and treaties as the "Law of the land," so that if constitutional supremacy and an equality of treaties and statutes is the proper order of authoritativeness, it is an order to be attributed not to the bare listings of the supremacy clause, but to basic principles. See U.S. Const. Art. VI.

151. Chae Chan Ping v. United States, 130 U.S. 581 (1889). 
to refuse "to execute a treaty" as a "prerogative" power involving a matter of the "utmost gravity and delicacy," but a power of which "no nation could be deprived without deeply affecting its independence."152 As such, it was a power which belonged to the Executive and Congress, to "diplomacy and legislation and not to the administration of existing laws."163 And while it was "not [to] be presumed that the legislative department [would] lightly pass laws which are in conflict with the treaties of the country," circumstances could arise "which would not only justify . . . but demand in the interest of the country that it . . . do so."154

An important point is implicit in all of this. The thought that treaty repudiation is a grave and dehicate matter testifies to the central role that treaties play, however inconsequential their immediate subject, in defining relationships between states. To say, however, that repudiation is a fundamental attribute of sovereignty such that no court may invoke the customary principle of respect for treaties to nullify a decision to repudiate, suggests even less authority in the courts to set up a less certain norin of customary international law as a bar to other political decisions of comparable import. The Paquete Habana confirms the point. ${ }^{155}$

\section{Of Principle}

Largeness of subject matter is not the only element to be considered in ascertaining the presence of a political question. While it is generally a necessary condition, it is rarely a sufficient one. A second element, the force to be ascribed to the values and principles seeking judicial vindication, must enter in. In none of the decisions reviewed, except perhaps the treaty repudiation cases, was the point of law advanced by those seeking an adjudication reflective of a clear and compelling principle. In cases like Neilson and Suffolk, the proffered conclusions of law had long and consistently been denied by the pohitical departments and were, at best, debatable. Decisions regarding the constitutional authority of a foreign official (Doe v. Braden) or a successor government (Terlinden) presented questions of foreign law laced with difficulties for an American court.

In this regard the cases are to be contrasted with the recent spate of circuit court decisions dealing with the war in Southeast Asia. In

152. Id. at 602 .

153. Id.

154. Id. at $600-01$.

155. See notes $115-120$ supra and accompanying text. 
spite of uncertainties in the fuller interpretation of their results, all three circuits that reviewed the question uniformly purported to affirm the judicial power to choose between peace and war, if that choice was ancillary to deciding whether the Executive had the constitutional competence to prosecute a war. ${ }^{156}$ This possibility, this thought that the

156. The focal point of all the challenges to the war was the absence of a formal declaration or other effective congressional authorization. The practical import in each instance was to embarrass, if not actually to terminate altogether, the Executive's ability to carry on military operations. In the earliest decisions, the District of Columbia Circuit and a three-judge district court dismissed as political questions all issues bearing upon the departmental allocation of the power to wage war. Mora v. McNamara, 387 F.2d 862 (D.C. Cir.), cert. denied, 389 U.S. 934 (1967); Luftig v. McNamara, 373 F.2d 664 (D.C. Cir.), cert. denied, 387 U.S. 945 (1967); Atlee v. Laird, 347 F. Supp. 689 (E.D. Pa. 1972), aff'd without opinion, 411 U.S. 911 (1973). By 1973, however, all the circuits having occasion to review the issue (First, Second and the District of Columbia) had asserted their authority to decide, on the basis of the nature and extent of the hostilities, whether some form of congressional authorization was constitutionally required, answering the question as applied to Vietnam affirmatively. Mitchell v. Laird, 488 F.2d 611 (D.C. Cir. 1973); Massachusetts v. Laird, 451 F.2d 26 (1st Cir. 1971); Berk v. Laird, 429 F.2d 302 (2d Cir. 1970). All the circuits, however, refused to take any action which might embarrass the Executive's conduct of the war, dismissing all of the complaints under one or the other of the Baker v. Carr political question criteria. The First and Second Circuits found sufficient authorization in the Tonkin Gulf Resolution, Pub. L. No. 88-408, 78 Stat. 384 (repealed 1971), and other congressional acts, saying that the form of the authorization and any further question as to the actual intent of those measures posed political questions. Massachusetts v. Laird, 451 F.2d at 33-34; Orlando v. Laird, 443 F.2d 1039, 1042-43 (2d Cir.), cert. denied, 404 U.S. 869 (1971). After the Resolution was repealed, the Second Circuit found that the President and Congress were winding down the war and declared that the method and means chosen for doing so were political questions. Da Costa v. Laird, 448 F.2d 1368 (2d Cir. 1971), cert. denied, 405 U.S. 979 (1972). The charges that additional congressional authorizations were necessary before the President could mine the harbors of North Vietnam, Da Costa v. Laird, 471 F.2d 1146 (2d Cir. 1973), or mount the Cambodian incursion, Holtzman v. Schlesinger, 484 F.2d 1307 (2d Cir. 1973), cert. denied, 416 U.S. 936 (1974), were characterized as challenges to tactical decisions, the judging of which was not susceptible to any judicially manageable standard. Even the District of Columbia Circuit, while asserting its power to decide that none of the proffered congressional authorizations showed an intent to sanction the continued level of hostilities, made its escape. The defendants were all Nixon Administration officials committed by policy, the court found, to ending the war. This the President could do as Commander in Chief without congressional warrant. How and at what speed it was accomplished was a political question, upon which a court would not substitute its judgment for that of the President absent a clear showing of "bad faith." Mitchell v. Laird, 488 F.2d at 616.

These decisions can, of course, be read as affirming the power of the judiciary to decide the question of war or peace, if that decision is for peace and is merely consequent upon deciding the issue of the Executive's constitutional competence to prosecute a war. Read thus, they may be thought to find support in the Prize Cases. See note 147 supra. On the other hand, apart from uniformly refusing to embarrass the conduct of the war, the courts affirmed their power to decide on the necessity of a congressional authorization only insofar as they were assured of finding just such an authorization, or finding that the decision for peace had been made, and the President was merely car- 
courts might properly decide so momentous an issue, shows that few if any instances potentially engaging the political question doctrine can be judged without regard for the countervailing importance of the principles for which judicial vindication is sought. Concern for judicial legitimacy deinands it. No less than action upon too "large" a question, a refusal to act upon a "large" principle can undermine the continumg effectiveness of the courts as instruments of governance.

In Sabbatino and Citibank, however, it seems rather plain that the principles at stake bore no resemblance whatsoever to the fundamental constitutional ideas advocated in the Vietnain War cases. If Cuba violated international law, Sardino stands as rather persuasive evidence that far froin reflecting a compelling principle, that law would require the American governinent to behave contrary to what the Constitution expressly permits if not impliedly endorses. Certainly an imternational norm that is contrary to basic constitutional standards must be appraised by the courts as embodying something short of a compelling social value. If the inportance of the acts of the American government that would run afoul of that norm are weighed agamst its dubious credentials and the result matched against the historical uses of the political question doctrine, the invitation to judge Cuba's decree according to that norm was rather clearly an invitation to decide a political question. On the other hand, if imternational law conforms to the Sardino calculus, then Sabbatino and Citibank engaged yet a third and final element of a political question.

\section{Of Judicial Competence}

Far from originating in forces exogenous to the social order, legal principles and the values they reflect emerge from the complex political, economic, cultural and historical forces at work on every individual in the definition of his needs and aspirations. As these forces are complex and work at cross-purposes, so the principles they produce will

rying out that decision. Certainly they used the political question doctrine to avoid any inquiry that might show that there was no authorization or that the President was not ending the war. In view of this they can also be interpreted as asserting a judicial power to act only where there is evidence that the authority for war has been explicitly withheld from the executive, i.e., where there is a direct conflict between the political departments. This is precisely the position taken by the three district judges in the only decision reviewed by the Supreme Court. Atlee v. Laird, 347 F. Supp. 689, 694 (E.D. $\mathrm{Pa}$. 1972), aff'd without opinion, 411 U.S. 911 (1973). And it might be thought to find support in the significance attributed by the Court in the Steel Seizure decision, Youngstown Sheet \& Tube Co. v. Sawyer, 343 U.S. 579 (1952), to the express refusal of Congress to authorize the actions the President later took on a claim of plenary power. 
often be confused and contradictory. Hence, the task of principled decision can and often does entail a difficult choice between competing, even contradictory principles, or between competing applications of a principle that is clear only at the highest levels of generalization.

In performing this difficult task the courts cannot ignore the complex forces that yielded up the difficulties in the first place. To do so can only produce exercises in judicial futility: results which at best are ignored, at worst flouted. Yet, precisely as the courts cannot ignore the coinplex realities that may intrude to render simple deductions futile, they cannot ignore the possibility that in attempting to draw out of those realities principles which will advance the national welfare, the realities may either defy anything they can describe with reasonable confidence, or will not yield to any fairly stable or tested body of predictive theory or judicial experience. ${ }^{167}$ Decision there must be, however untidy the social forces with which decision inust grapple. But as the complexity and uncertainty inherent in the analysis of these forces increases, the responsibility for choosing annong contending values or determining the application of a general principle moves toward the exclusive province of the more representative institutions. Even if the perceptive capabilities of legislators and administrators are no better than those of judges, as uncertainty increases those departments stand in their more rigorous accountability to the electorate as the surer exponents of what is perceived by the latter to be the national interest. And the cases illustrate the point.

Justice Frankfurter gave soine expression to this view in Ludecke v. Watkins. ${ }^{158}$ It is also present in the commitment of the question of the recognition of foreign governments to the Executive. Although as a result of the commitinent, decisions have been perineated with considerations of expediency, this does not explain the commitment in the first place. ${ }^{169}$ What is to be observed, it is submitted, is an intractable problem of choice between contending sets of principles. For the fact is that principles abound, and are no less discernible by the courts than by the Executive. ${ }^{160}$ Nor is there reason to believe that courts could

157. See the discussion of this problem in Bickel, supra note 127.

158. 335 U.S. 160 (1948). See note 147 supra.

159. On this point we deal with what was described in Baker v. Carr, 369 U.S. 186 (1964), as "the impossibility of deciding without an initial policy determination of a kind clearly for nonjudicial discretion." Id. at 217. Again we have an observed function, not a standard for determining when the function must be carried out-what questions are "clearly for nonjudicial discretion"?

160. There has been, on one hand, what Hackworth describes as the dominant United States practice since Jefferson's time. The decision to recognize a government (de jure or de facto) has been predicated upon a factual test of actual control, general popular 
not at least attempt to articulate criteria for reasoned selection from among those contending precepts. Rather, since no principle is free from the ultimate utihtarian (i.e., national welfare) test, the commitment of the issue to the Executive reflects two basic considerations. There is first the centrality of the question to all policy in the sense already explained. Combined with this is a realization that, because the considerations (geopolitical, economic and ideological) which must ultimately deterinine whether any principle serves the national welfare lie so far beyond the competence of the courts to assay, the latter have no adequate basis for assuming that any judicially constructed criteria of choice would, on the whole and over time, meet the test of utility. If there is an absence of a "judicially discoverable and manageable standard,"101 it stems not from any lack of standards from which to select, but from a sense that the limits of judicial competence render other departments the proper organs to make the selection.

In like fashion, the effect to be given legislation that is inconsistent with a subsisting treaty is not a subject lacking discernible principles. ${ }^{162}$ It is rather the largeness of the question (probably the more decisive

acquiescence and the ability (and willingness) to discharge international obligations. 1 G. HACKWORTH, Digest of INTERNational LAw 174-76 (1940). Under this practice the line between de facto and de jure recognition seems to be essentially a matter of degree- "how firmly established" is the new regime, as one British Foreign Secretary characterized the comparable British practice. Statement by Foreign Secretary Morrison Before the House of Commons, Mar. 21, 1951; 485 PARL. DEB. H.C. (5th ser.) 2414 (1951). It ignores entirely considerations drawn from the character of that regime or the mode of its accession to power. Certainly this practice could be employed as a principle for judicial decision and, as sucb, could be justified as serving important national objectives. And the courts could readily make the factual determinations necessary to implement such a principle. On the other hand, the same history is one of recurrent resort to other principles, in the matter of de facto as well as de jure recognition. There was, for example, President Wilson's effort to make "Constitutionalism" a prerequisite to recognition, see [1913] FoRErGN REL. U.S. 7, an effort reflected in the Central American Treaty of 1907,1 G. HACKWoRTH, supra, at 185, and the U.S. acceptance of the provisions of the 1923 Treaty of Peace and Amity among five Central American nations, see id. at 188. There was also the refusal to recognize (i) Manchukuo as a matter of conforming to certain League of Nations resolutions, id. at 333-38, (ii) Albania, inter alia, because that government was not established in conformity with the principles of the Crimea Declaration on Liberated Europe, 17 DEP'T OF STATR BulL. 409 (1947); 15 id. 913 (1946); 13 id. 767 (1945), and (iii) Communist China because of "that country's efforts to destroy the band of free nations," 38 id. $164-65$ (1958).

161. Baker v. Carr, 369 U.S. 186, 217 (1962).

162. John Jay's confident assertion that the courts should simply enforce the nation's international obligations even in the face of a legislative dereliction (although the nonself-executing treaty might pose a problem) is certainly one principled solution to the problem. See note 148 supra. If this is too harsh, there is no lack of traditional amelioriative doctrines from which a better balanced body of judicially enforceable standards of national conduct might be fashioned. 
factor) combined with the complexity and subtlety of the political and other considerations ultimately determining which principle would best serve the national interest, that places the matter beyond the judicial purview.

Turning then to Sabbatino and Citibank, the focus of interest is the Sardino formula. ${ }^{163}$ It inay be assumed arguendo that that forinula is fully reflective of international law, and that by sanctioning certain deprivations it can serve as an important constraint upon some of the inore excessive forms of confiscatory action to which governments are prone. Yet, when one considers the extraordinary difficulties of arriving at the impartial characterization of Cuba's actions upon which that forinula depends, a concern for judicial competence comes to occupy an important place in the case. Cuba's historical relationship with the United States, the swift and drainatic changes in that relationship wrought by the Castro Revolution, the ideological and military implications of that revolution, and the nature of the American response all warn against viewing any particular judgment as the vindication of an important principle. If the primciple is important in the abstract, its application to the particular case is far too complex and attended by too many uncertainties to warrant viewing any decision as the expression of sonie overriding social imperative. When this realization is nuatched against the foreign policy implications of a judgment validating Cuba's decree (i.e., largeness of the question) and those implications are in turn nuatched against the historical uses of the political question doctrine, it becomes clear beyond peradventure that the invitation to judge in Sabbatino and Citibank was an invitation to decide a political question.

\section{Summary}

The larger lesson is again clear. With a frequency not encountered in doinestic disputes, two questions are likely to arise in any trans-

163. Obviously relevant here is Justice Harlan's observation of the disparity of views regarding international law and his sense that this disparity indicated a dearth of "agreed principles" from which the courts could work. Sabbatino, 376 U.S. at 428-30. Possibly issues can arise where the lack of agreed principles suffices to signal a void into which no court, under any circumstances, can intrude. But such is not our case. There is more than enough in the traditional international law of expropriations and in the Sardino case, to mention only a few sources of potential enlightenment, from which the courts could work in accordance with some of the best and most creative traditions of judicial reasoning. In our setting, the disparity of views and the absence of agreed principles must be juxtaposed with the other elements in the political question formula. The difficulty, in other words, of ascertaining the controlling rule of decision in our case-the degree to which that task may challenge the competence of the judiciary-is basically 
national dispute before a domestic court when international norms are at issue. First, given the sources of its authority and its ultimate allegiance to that authority, can a domestic court be counted upon to apply international norms in keeping with their postulated universality? Are there not limits to the power of the court to apply those norms evenhandedly against its own government as well as against others, especially if those norms differ from domestic law? And second, are there not other institutions and other techniques better fit for the task of conflict resolution and the protection of individual rights? To accept the challengers' formulation of the act of state doctrine-of deference and comity - and thus to ignore these two questions is to invite the distortions evident in the Citibank decision. On the other hand, an acknowledgment of the centrality of these questions in any decision regarding act of state will result in the recasting of the theoretical underpinnings of the doctrine.

Act of state is a rule concerned with keeping the courts within their proper sphere under the American constitutional system. No less than political question, it is rooted in a respect for the consensual nature of all law. Yet because of its explicit transnational component-the act of a foreign state-it also reflects a concern for the international order and the perfection of international norms as instruments for controlling the behavior of nations. It thus seeks to secure against that degradation of international norms which is inevitable unless an lonest answer is given to the first question. And because it rests upon a broader, functional view of law, the abstention necessary to protect against such degradation becomes a positive force in the search for the rule of law among nations. Its underpinnings, in short, are found in that demand for judicial legitimacy which is ultimately constitutional. But the boundaries of legitimate action reflect the unique transnational setting in which the doctrine operates. And while those boundaries may certainly encompass a classic political question, they need not do so. Dunhill illustrates that point.

\section{The Dunhill Decision}

Once the Supreme Court in Dunhill determined to let stand the lower courts' denial of Cuba's claim to the pre-intervention accounts receivable, and to treat only the failure to return the importers' pay. ments on those accounts, it was able to proceed as though no interna-

relevant only because it points to the absence of a compelling principle or to a high potential for disrupting foreign policy. Mere difficulty in finding the controlling international consensus is not sufficient to warrant withdrawal from the atteinpt. 
tional law questions were directly raised in the case. The issue was simply whether act of state should bar enforcenent of the obligation to return the payinents-an obligation imposed upon the interventors, in the district court's view, by the law of New York, ${ }^{164}$ but one which the Second Circuit saw as having its "situs" for act of state purposes in Cuba. ${ }^{165}$

Notably, in approaching this question all of the judges exhibited a propensity to search for answers in some general, abstract and selflimiting defimition of what constitutes an act of state. To the extent the doctrine's purposes entered into this search there was an equally notable preoccupation with a single factor: that of avoiding judicial embarrassments to foreign policy. Even Justice Marshall, while alluding to the existence of other purposes, nowhere explored what they might be. The Second Circuit contented itself with the observation that the courts could embarrass foreign policy by judging the contractual acts of foreign governments as readily as by judging their expropriatory acts. ${ }^{106}$

If any of the judges had kept an eye on the broader range of purposes catalogued by Justice Harlan, they imight have noted that had a Cuban debtor mistakenly paid money to an American citizen and recovered judginent in the courts of the United States on a theory of unjust enrichment, all payments under that judgment would have been blocked under the Cuban Assets Control Regulations. ${ }^{167}$ While the law of New York nuight have conferred a cause of action upon the Cuban plaintiff, federal law would have intervened to deny limi recovery on that cause of action temporarily and, more likely than not, permanently. Had any of the judges, in other words, consulted the doctrine's broader purposes, they might have reshaped the central act of state question altogether: were the American courts to hold that, while under American law a Cuban citizen with a claim for unjust enrichinent might rightfully be barred by the American government fron 1 recovering upon that claim, it was nevertheless wrongful, again under American law, for a foreign government to deny an American recovery upon an identical claim? And this was indeed the issue.

164. Menendez v. Faber, Coe \& Gregg, Inc., 345 F. Supp. 527, 543-45 (S.D.N.Y. 1972).

165. Menendez v. Saks \& Co., 488 F.2d 1355 (2d Cir. 1973). The Second Circuit nowhere expressly considers the district court's resort to the law of New York as establishing the interventors' obligation. It simply holds that for act of state purposes, that obligation bad a Cuban "situs."

166. Menendez v. Saks \& Co., 485 F.2d 1355, 1370 (2d Cir. 1973).

167. $C f$. the Treasury Department letter, discussed in note 44 supra. 
All the Justices agreed that the Cuban government had in fact barred return of the mistaken payments-that it was not just a default by the interventors acting without governmental authority. ${ }^{108}$

Perhaps to pose the question is to invite the answer. Nevertheless, it may be argued that, in appropriate circunnstances, the responsibility of the American courts to protect domestic interests can warrant condeinning foreign deprivations-to use Judge Friendly's phrase ${ }^{109}$ against American citizens while approving comparable American deprivations against aliens. ${ }^{170}$ To invoke such a rationale in Dunhill, however, is to take the case out of context. Such protective purposes as might have justified the double standard were already being pursued through the very pohtical department actions-the blocking of Cuban assets-that raised the problem in the first instance. Since the Court could have used act of state and thereby avoided compromising the importers' position, ${ }^{171}$ its implicit sanction of a double standard-assun-

168. Justice White supplied the definitive characterization by calling the interventors' refusal to repay nothing more than an assertion "that the preintervention accounts receivable were theirs and that they had no obligation to return payments on those accounts." Dunhill, $96 \mathrm{~S}$. Ct. at 1860 . From this the Justice concluded that since the initial claim to the accounts was not entitled to act of state protection, the failure to return the payments on those accounts was not an act of state. For immediate purposes, however, the conclusion is beside the point. The fact was, as Justice White acknowledged, that Cuba claimed the accounts receivable; it made that claim by its decree of September 15,1960, and the effect of that decree was to bar return of the mistaken payments. Quite apart from whether an American court should recognize that claim, the fact of the claim sufficed to establish an act of the Cuban government indistinguishable from the regulations of the United States government which would have barred payment to a Cuban citizen on an identical cause of action. Also notable is Justice White's point that an American court should not, absent proof, attribute to the Cuban government any act subsequent to September 15, 1960 confiscating the importers' payments when they arrived in Cuba, and should not, absent proof, charge that government with repudiating its obligations. Id. at $1860 \mathrm{n} .8$. These conclusions may be correct, but they are immaterial.

169. See Sardino v. Federal Reserve Bank, 361 F.2d 106, 111 (2d Cir.), cert. denied, 385 U.S. 898 (1966).

170. Sucl a possibility, of course, did not exist in either Sabbatino or Citibank where the claims of C.A.V. and the Bank rested upon international law. Presnmably, even in the hands of national courts, what international law permits one nation to do, it permits another.

171. Under $\S 503$ of the International Clains Settlement Act, 22 U.S.C. $\S 1643 b$ (a) (1970), the Foreign Claims Settlement Commission is empowered to "receive and determine in accordance with applicable substantive law, including international law, the amount and validity of claims by nationals of the Umited States against the Government of Cuba." The claims the Commission is authorized to determine include claims for debts "owed by the Government of Cuba or . . . by enterprises . . . intervened" by that Government, 22 U.S.C. $\$ 1643 \mathrm{a}(3)$ (1970). Under these provisions the Commission, in addition to determining claims under international law, justice and equity, see Claim of Isabella Shamma, 1972 FCSC Ann. Rep. 228; Claim of American Cast Iron 
ing that the Cuban Assets Control Regulations are valid-represented only a somewhat less egregious coinpromise of judicial integrity than the decision in Citibank.

First, if Dunhill, Inc., even though an American company, would have been denied access under current laws and Executive practice to any political settlement of American claims because of its foreign ownership, ${ }^{172}$ the argument for a double standard in its case would liave had to be dismissed out of hand. It would hardly do for the American courts to compromise the basic integrity of their own law in order to vindicate a claim which not even the political departments were prepared to support in furtherance of the larger interests of the nation. But even as applied to the other importers, and arguendo to Dunhill because current practice might cliange, the argument for a double standard carmot stand.

Counsel for Dunhill argued that their client's claim was not nooted merely because the corporation would have been barred by the Treasury Department from executing its judgment against the sums owed to Cuba by the other importers. ${ }^{173}$ As a judgment creditor, counsel suggested, Dunhill might still have had access to a future settlement of American claims, presumably imcluding a settlement through the use of blocked funds. Leaving aside the special problems of Dunhill's ownership, and applying the argument to all the importers, it is well to note that access to such a settlement is not dependent upon the reduction of a claim to judgment. The argument, in other words, also establishes that the importers' access would have remained unimpaired even liad their claims been dismissed by the Court, provided the dismissal was without prejudice to the legal sufficiency of the claims. And

Pipe Co., 25 FCSC Semiann. Rep. 49 [July-Dec. 1966, has recognized claims arising under the law of Pennsylvania, Claim of James Keyes, 1968 FCSC Ann. Rep. 75, and under the laws of Cuba, Claim of Robert L. Cheaney, 1972 FCSC Ann. Rep. 154. See generally Re, The Foreign Claims Settlement Commission and the Cuban Claims Program, 1 INT'L LAW. 81 (1966).

172. Section 502(1) of the International Claims Settlement Act, 22 U.S.C. $\$ 1643 \mathrm{a}$ (1) (1970), defines a United States national as, inter alia, a U.S. corporation $50 \%$ or more beneficially owned by United States citizens. Also, in determming participation iu all the post-World War II lump-sum settlements, the State Department required substantial U.S. ownership of American corporations (generally 50\%), although earlier examples exist where the Department ignored the ownership of such companies altogether. R. LIflich, International Clatms: Their Preparation and Presentation 15-17 (1962). Certainly international law does not establish such a prerequisite to the diplomatic espousal of the claims of a corporation organized under United States law. Cf. Barcelona Traction, Light \& Power Co. (Belgium v. Spain) [1970] I.C.J. 3.

173. Supplemental Brief for Petitioner, at 2, Dunhill, 96 S. Ct. 1854 (1976). See the discussion of the mootness question at note 44 supra. 
plainly, since act of state is a rule of judicial abstention from judgment on the merits, the Court could have invoked that doctrine to dismiss the importers' counterclaims without formally impugning their sufficiency under those alternative devices. It could have avoided announcing a double standard (i.e., that Cuba's act was wrongful) while preserving the political department's ability to assert or otherwise recognize that allegation. ${ }^{174}$

Equally important, the Court in pursuing such a course would not have had to note the possible similarity between Cuba's actions and the American blocking of Cuban assets, thereby risking the implication that because the latter was constitutional, Cuba's actions were likewise proper. One of the purposes, and in it the wisdom, of Justice Harlan's broad interdiction is the avoidance of all judicial pronouncements, not merely those invalidating foreign state acts. One may even read his opinion as an elliptical forewarning of just such difficulties, skillfully crafted to secure against the very dangers with which it was concerned. In summary, once the political mechanism was in place and the possibility existed for using act of state to relegate the importers' claims to that mechanisin, a decision by the Court to protect its own integrity by invalidating those claims was unnecessary, while the decision to compromise that integrity by affirmatively validating the claims (i.e., permitting the offsets) was wholly unwarranted.

More specifically, when the Court refused to recognize Cuba's claim to the pre-intervention accounts receivable, it effectively decided that American citizens, not the origimal Cuban owners, were to bear the loss from Cuba's taking of those accounts. The blocking of Cuban assets further compounded the problem, leaving the Court essentially three choices. It could, in the nanie of its own integrity, have declared that because Cuba had not acted wrongfully the importers had no cause

174. It is to be kept in mind that the problem of a double standard which a court would have to consider is not a matter germane to the validation of the importers' claims by the Executive or to their espousal in any negotiated settlement. The importers' injury was a fact, so long as they had to pay twice. Assuming, therefore, that the claims could be sustained upon grounds of either international law or justice and equity, they would still be cognizable by the Executive in spite of the United States' blocking of Cuban assets, since the basic purpose of Executive espousal is to redress the real grievances arising out of past hostilities and their attendant deprivations. The Executive properly asserts the American claims without regard to whether it may have acted in kind, Cuba does the same, and settlement proceeds from that point. While the Foreign Claims Settlement Commission appears to have thought that it might be required to apply the act of state doctrine, Claim of James Keys, 1972 FCSC Ann. Rep. 154; see Claim of Brower, 19 FCSC Semiann. Rep. 18 [July-Dec. 1963], this is a highly dubious proposition generally, and certainly inapplicable in this setting, a point upon which the Court might well have instructed the Commission. 
of action, and should therefore bear the whole loss. Or, the Court could have compromised its own integrity, declared the Cuban actions wrongful, granted the importers a set-off (i.e., a preference) and thereby visited the whole loss upon other Americans with claims against Cuba. This is, of course, what it chose to do. Lastly, it could have abstained under act of state, avoided sanctioning a double standard, and compelled the miporters and the other American claimants to share the loss equally. A denial of the set-off would have increased the potential aggregate recovery of all American claimants, which, if less than the amount of those claims, would have meant that the importers shared some of the loss. At the saine time the importers' claims would, by diluting the anount of the individual shares recovered, have required the other claimants to share in the loss. ${ }^{175}$

Possibly, absent other considerations, a preference for the importers could be justified. ${ }^{178}$ But once that preference also required the Supreme Court of the United States to approve a double standard under American law, there would appear to be no justification whatsoever for the decision. This is all the more so because a decision of the Supreme Court carries far greater weight in defining that state practice from which an international norm may evolve than does any pronouncement by the political departments on a point of immediate national interest. Dunhill stands, in short, as an invitation for other nations to practice a discrimimation which, in the broader view, can hardly serve either the interests of American investors or the larger cause of good order in the international community.

Finally, it must be acknowledged that notwithstanding the existing authority of the Foreign Claims Settlement Commission to vahidate the

175. Consult the careful explanation of this point by Judge Lumbard in his Citibank opinion, 431 F.2d at 404 n.18. The point is one of elementary alternative cost analysis. The question of who bears the loss of the pre-intervention accounts is to be determined by comparing the gains or losses of each group (importers versus other clainants) under the several alternatives available to the court. Since the Court could have denied the importers' claims altogether, thereby increasing the other claimants' potential recovery by the full amount of the pre-intervention payinents, any alternative decision which reduces the other claimants' potential recovery represents a decision to impose upon those claimants all or part of the loss of the pre-intervention accounts. Because the allowance of the set-off reduced the other claimants' recovery up to the full amount of the preintervention accounts, they actually bore the full impact of the loss-a loss occasioned not by their own actions, but by those of the importers. To have remanded the importers to the political mechanisin would have meant a sharing of the loss, since the other claimants would recover less than under the first alternative (i.e., they would bear some loss) and the importers would recover less than under the latter alternative (i.e., they would bear soine loss). The sharing is pro rata.

176. See Part II supra. 
importers' claims, ${ }^{177}$ recovery on those claims is likely to depend largely upon the outcome of some future negotiation with the government of Cuba for a lump-sum or other settlement. There is also some possibility that the State Department might decline to espouse those claims as part of such a settlement on the grounds that they were not cognizable under international law. Were the Court, however, to have cited this possibility as a basis for refusing to remand the importers' claims, especially if advised of the possibility by the State Department, it plainly would have had no recourse but to invalidate the claims altogether.

If the possibility were sufficient to bar remand, it would certainly have sufficed to suggest the compelling danger that any judgment granting the importers a set-off against funds legally belonging to Cuba was an offense against the very rights of Cuba as a sovereign state which the United States had claimed for itself. At this point the issue would have been not whether there should be a double standard under American law, but whether the United States should, by applying that standard, violate its obligation to respect the very rights of a foreign sovereign which it had demanded for itself. In the context of claims for approximately $\$ 477,000$ which not even the State Department would espouse, the obligation of the Court to uphold international law was plain.

Thus act of state again emerges rooted in considerations which no theory of nere deference to the Executive can possibly capture. And since, in the Dunhill context, it may be doubted that the problen for the Court rose to the status of a classic political question under the historical standards already discussed, act of state, if not commanded by the Constitution, may nevertheless be seen as firmly footed upon constitutional underpinnings.

\section{SUMMARY AND FORWARD LOOK}

\section{A. The Further Inquiry}

It should be obvious that the foregoing critique of the Cuban cases is based upon their very special and limiting context-a hostile political climate capable of precipitating nutual acts of deprivation. It is by no means self-evident that judicial actions renoved froun this setting will have a comparable impact upon policy, upon private rights, upon the integrity of the courts or upon international law. It cannot be assumed that one will find in the particular circumstances that may have necessi-

177. See note 171 supra. The statement is subject to the qualification in note 172 supra. 
tated the results in Sabbatino a warrant for Justice Harlan's broad interdiction. Whether such an extension can be justified is the question for the remainder of this Article. As preface to that inquiry, a few general observations will einphasize the pertinence of the question and aid in pursuit of the answer.

Without unuch doubt the classic statement of the doctrine-that "the courts of one country will not sit in judgment on the acts of government of another done within its own territory"178_begs the question. The courts of the United States do sit in judgment upon the acts of a foreign government, except where they do not do so because of the act of state doctrine. They judge whether those acts are offensive to their own public pohicy or to international law. ${ }^{179}$ In the case of foreign judgments, they pass on the adequacy of the rendering court's claim of jurisdiction, the essential fairness of the procedures einployed, and the conformity of the decision to the fundanentals of American public policy. ${ }^{189}$

Nor can the doctrine's anbit be defined by autonatically limiting its application to executive acts and excluding all legislative or judicial acts. If in nineteenth century usage "acts of government" meant only executive actions, contemporary experience compels a total rejection of any such limitation. The courts liave in fact apphed act of state to a wholly private dispute where only a foreign legislative enactment, divorced froin any executive act, was involved..$^{181}$ In both Sabbatino and Citibank, while the seizures at issue were carried out by the Cuban executive, it was Law 851 itself and the circumstances of its issuance that were the exclusive subject of judicial scrutimy.

The fact that a foreign government is willing to submit its acts to the scrutiny of its own courts may weigh in assaying the consequences of submitting that act to American judicial scrutiny. But given the propensity of contemporary governments to protest their adherence to legal forms, and the advantages to be gained from appearing to follow those forms, there is scarcely a governmental purpose that might in an earlier day have been accomplished wholly by executive decree that today will not be the subject of subsequent judicial enforcement. The judiciary inay be wholly subservient to the will of the executive, but the form persists.

178. Underhill v. Hernandez, 168 U.S. 250, 252 (1897).

179. See Henkin, supra note 72.

180. Hilton v. Guyot, 159 U.S. 113 (1895), is the leading case.

181. See, e.g., Holzer v. Deutsche Reichsbahn-Gesellschaft, 277 N.Y. 474, 14 N.E.2d 798 (1938). 
In like fashion, Dunhill warns against any limitation based upon general and somewhat abstract subject-matter categories. An exception for all commercial obligations, or all acts by agents with commercial (as distinct from sovereign) powers or for regulatory or contractual actions, as distinct from expropriatory acts, is folly. Attempted comparisons to sovereign immunity are fragile at best. Act of state is rooted in the perceived threats to judicial legitimacy which may attend efforts to judge a foreign state act on its merits. Only in their common concern to avoid direct embarrassments to foreign policy may a somewhat fortuitous convergence of the two doctrimes occur. And careless statements calling act of state a "claim of immumity in disguise" are wholly misplaced. ${ }^{182}$

There is, in short, no ready definition. The touchstone is purpose. Any exercise or refusal to exercise power by any agency of a foreign government, by whatever mode and with whatever object in mind, is an act of state, if an American court, consulting the sources of its own legitimacy and the requirements of justice, determines that it must be so.

But this definition also begs the question unless one can replicate, in the wider setting of Justice Harlan's interdiction, those particular threats to judicial legitimacy that were present either in the Cuban cases or their precursors. And the fact is that the boundaries of the doctrine laid down by the pre-Sabbatino decisions of the Supreme Court can be read in a very limited fashion indeed-a fashion warranting application of the doctrine in Sabbatino and Citibank, but no more. It is not that the leading cases must be read in this restricted way. The lower courts have not done so. But since the latter provide little by way of explanation-the classic statement usually suffices-any rigorous test of the Sabbatino rule must cominence by acknowledging that it was not compelled by any existing Supreine Court authority.

In rejecting a claim for darnages arising out of an armed insurrection in Venezuela, the Court in Underhill v. Hernandez ${ }^{183}$ clearly recognized the distinctiveness of that case. ${ }^{184}$ Insurrection as a means

182. See Brief for the United States as Amicus Curiae, at 26, Dunhill, 96 S. Ct. 1854 (1976).

183. 168 U.S. 250 (1897) (suit by American citizen held captive and otherwise injured by Venezuelan revolutionaries later recognized as legitimate government by United States).

184. Id. at 254. It is nowhere clear from the case upon which law plaintiff based his cause of action. If, as normal choice of law rules would indicate, Venezuelan law was controlling, the Court might well have found a total lack of basis for the claim. The case might also have been disposed of on sovereign immunity grounds. 
of governmental change was a growing phenomenon. Claims for damages from such events were certain to increase. The problein was to fashion a general judicial response to such claims in cases where the Executive had later recognized the party perpetrating the injury as the legitimate government of the foreign country. Seen from this perspective, the entire opinion shows how thoroughly the Court desired to avoid imperiling the whole relationship between the United States and a foreign government that was implicit in the act of recognizing the latter. ${ }^{185}$ It was responding in terms not unlike those undergirding the classic political question decisions already reviewed.

In Oetjen v. Central Leather Co. ${ }^{186}$ and Ricaud v. American Metal Co. ${ }^{187}$ the link to the recognition power appears much more explicit. Act of state, as one of a triunvirate of principles, was necessary to give full operative effect to the other two precepts: the principle that the recognition power was altogether political and the principle that recognition retroactively validated all actions of the newly recognized government. ${ }^{188}$ In the Litvinov Assignment cases, it was the imextricable relationship between those Assignments and the recognition of the Soviet government that led the Court, using act of state, to recognize the underlying Soviet expropriatory decrees. ${ }^{189}$ United States v. Bel-

185. It was dealing, the Court said, with an act of "legitimate warfare [which] cannot be made the basis of individual liability." Id. at 253 . It was a civil war, the merits of which "generally speaking foreign nations do not assume to judge." This being so, once the victors had been recognized by the Executive, it would be "idle to argue" that they were "banditti or mere mobs." The case was entirely distinguishable from decisions dealing with piracy, with contracts in aid of insurrection and with military arrests removed from the context of war. Hence, the "redress of grievances by reason of such acts" was the province of diplomacy. Id.

186. 246 U.S. 297 (1918) (seizure of animal hides by Mexican insurgents who prevailed and were recognized as de jure government of Mexico).

187. 246 U.S. 304 (1918) (seizure of lead bullion shipment under same circumstances as im Oetjen).

188. In Oetjen, plaintiff alleged that the seizure violated international law. Although disposed to find no such violation, the Court, noting that similar "claims . . . [were] being made in many cases in this and in other courts," preferred to rest its decision on the "three clearly settled principles of law" noted above. Id. at 302.

189. Although in M. Salimoff \& Co. v. Standard Oil Co., 262 N.Y. 220, 186 N.E. 679 (1933), the impact of the de facto recoguition of the Soviet government is apparent, it must be conceded that lower conrt decisions dealing with the Soviet decrees cannot be explained in terms of the existence or not of a comparable linkage to the recognition power. This is underscored by the fact that even when confronted by the linkage of the Litvinov Assignments, the New York Court of Appeals refused to apply act of state in Moscow Fire Ins. Co. v. Bank of New York, 280 N.Y. 286, 20 N.E.2d 758 (1939). If the Soviet decrees were intended to apply to assets in the United States they were, the court held, unenforceable as contrary to public policy. While the decision was affirmed by an evenly divided Supreme Court, 309 U.S. 624 (1940), its continued force 
mont $t^{100}$ is the definitive illustration. ${ }^{101}$ There, Justice Sutherland, after noting the Oetjen linkage, forged such a close inderdependence between the two that, on the facts before him, he found the rationale for applying the act of state doctrine in the political act of recognition. ${ }^{102}$

has, I suggest, been substantially undermined if not overruled by United States v. Pink, 315 U.S. 203 (1942). Also, in Vladikavkazsky Ry. Co. v. New York Trust Co., 263 N.Y. 369,189 N.E. 456 (1934), while the circuinstances of de facto recognition were the saine as in Salimoff, the doctrine was not applied since the situs of the property in question was said to be New York. In cases where the foreign act was not considered extraterritorial, such as Dougherty v. Equitable Life Assurance Soc'y, 266 N.Y. 71, 193 N.E. 897 (1934), Holzer v. Deutsche Reichsbahn-Gesellschaft, 277 N.Y. 474, 14 N.E.2d 798 (1938), and the first Bernstein case, Bernstein v. Van Heyghen Frères S.A., 163 F.2d 246 (2d Cir.), cert. denied, 332 U.S. 772 (1947), involving Nazi racial decrees, much less was made of the recognition point, although, of course, recognition was considered necessary to the application of the doctrine. Compare pre-recognition cases such as Petrogradsky Meijdunarodny Kommerchesky Bank v. National City Bank, 253 N.Y. 23, 170 N.E. 479 (1930), and Russian Reinsurance Co. v. Stoddard, 240 N.Y. 149, 147 N.E. 703 (1925), where non-recognition was obviously important, although no less than the fact that the assets were thought to have a situs in New York. In Wulfsohn v. Russian Socialist Federated Soviet Republic, 234 N.Y. 372, 138 N.E. 24 (1923), writ of error dismissed, 266 U.S. 580 (1924), disnissal of plaintiff's tort claim for seizure of assets located in Russia was predicated more upon sovereign immunity than act of state.

As discussed in Part V of this Article, such non-extraterritorial cases as Salimoff, Dougherty, Bernstein and Holzer fall within a distinct category of situations to which act of state was properly applied. This application represents, nevertheless, an extension of the precise constitutional underpinnings which undergird the Supreme Court decisions reviewed to this point.

Of the more recent non-Cuban decisions, Occidental Petroleuin Corp. v. Buttes Gas \& Oil Co., 331 F. Supp. 92 (C.D. Cal. 1971), aff'd per curiam, 461 F.2d 1261 (9th Cir.), cert. denied, 409 U.S. 950 (1972), rests upon a classic constitutional footing. There, one of the Trucial States in the Persian Gulf, allegedly as part of a conspiracy in violation of the United States antitrust laws, laid claim to the territory of another such state within which territory the latter had granted plaintiff an oil concession. As a result plaintiff lost his concession. The validity of the first state's claim to territory was plainly a political question under the authority of such cases as Suffolk and Jones, discussed in notes 131-33 supra and accompanying text.

190. 301 U.S. 324 (1937) (action to recover money formerly belonging to Russian corporation and assigned by Soviet government, after expropriation, to United States).

191. The other major Litvinov Assignment cases were United States v. Pink, 315 U.S. 203 (1942); Moscow Fire Ins. Co. v. United States, 309 U.S. 624 (1940); Guaranty Trust v. United States, 304 U.S. 126 (1938). In Moscow, an evenly divided Court upheld the New York Court of Appeals' judginent that the Soviet decrees were either not intended to have extraterritorial effect or, if so intended, were unenforceable as contrary to public policy. In Pink, however, the Court held that the Moscow Court's decision was not an "authoritative precedent," and proceeded to uphold the Government's claim based upon the Soviet decrees. In doing so, Pink purported to adopt the Belmont rule, but Belmont was clearly used in a subsidiary role, the main point being the constitutionality of the Assignments. See note 100 supra.

192. For this position, Justice Sutherland relied principally upon Lord Scrutton's deeision in Luther v. James Sagor \& Co. [1921] 3 K.B. 532, especially that passage where 
Starting with the boundaries suggested by these cases, several conclusions seem to follow. The constitutional underpinnings of the doctrine can scarcely be demed. And while in Sabbatino the Court could not have relied upon a comparable linkage between Cuba's acts and the recognition power per se, the linkage to those elements undergirding the characterization of that power as pohtical-the largeness of subject and the matter of judicial competence-was, as already suggested, quite plain. Sabbatino represented only a modest extension of the earlier decisions, if any extension at all. Citibank and Dunhill, in turn, demonstrate the wisdom of that extension.

This conclusion, however, underscores the breadth of the potential gap between the particular circumstances which justified the results in Sabbatino and the broad ruling which emerged from the case, a gap Dunhill fails to close. In the absence of guidance from the Court, our only course is to postulate a rough catalogue of situations where the act of state doctrine might appear to serve purposes analogous to its role in the leading cases (Section B of this Part) and then to examine

the Lord Justice insisted that "the responsibility for recognition or non-recognition . . . rests on the political advisers of the Sovereign and not on the judges." Id. at 559.

Lord Scrutton plainly was not suggesting that every legislative act of a recognized foreign governinent had to be recognized by the courts of England. It was only that judicial non-recognition of the Soviet legislation in that case would have undermined, if not actually repudiated, the political decision to extend de facto recognition to the Soviet government. A glance at the context underscores the point. The British grant of de facto recognition to the Soviets had just occurred; the two governinents had, a month before, signed a trade agreeinent which anticipated the equitable settlement of precisely the kind of claim that was before the court. The year was 1921. Western intervention against the Soviet revolution had just come to an end. The Soviets were attempting to re-establish commercial and financial relationships with the Western powers, and the latter were reciprocating. Against this background, Lord Scrutton, in speaking of the question of "recoguition," was referring unambiguously to both the political question of de facto recognition of the Soviet governinent and the question of judicial recognition of Soviet decrees. They were inextricably connected. Preservation of the integrity of the political decision was a bar to any course other than judicial recognition.

Of the American cases, only Shapleigh v. Mier, 299 U.S. 468 (1937), and Ainerican Banana Co. v. United Fruit Co., 213 U.S. 347 (1909), do not readily fit this particular linkage of act of state to the recognition power. Both involved the seizure of American property by a foreign government, but neither occurred in the narrow context of an insurrection by a party later recognized by the United States, and in neither did the Court evince any particular sensitivity to the impingennent of the case upon the recognition power or upon the larger relationship between the United States and the foreign power. In both, nevertheless, the Court's treatment of the doctrine was perfunctory at best. In Shapleigh the party complaining of the expropriation conceded the validity of the doctrine and offered no serious test of its linits; the Court noted that a claim had already been filed with a commission jointly established by the United States and Mexico. In American Banana, the doctrine's use was closely related to Justice Holmes' more faunous dictum constraining the extraterritorial reach of the antitrust laws, a holding effort long since abandoned by the Court. 
how and to what extent this may be so (Part V). In this effort lower court decisions are suggestive, but by no means definitive, and the catalogue is far from exhaustive.

\section{B. A Catalogue of Wider Uses}

\section{Of Scope}

Since our purpose is to discern the potential effects of judicial action in the wider circumstances envisioned by Justice Harlan, several considerations militate against confining the inquiry solely to disputes over foreign expropriatory acts (the direct taking of title to property), even though these were obviously the focus of the Justice's concern. The courts have not drawn any arbitrary, formalistic lines around the act of state doctrine. ${ }^{103}$ There is certainly no a priori reason why judgments regarding foreign regulatory acts or contract repudiations cannot have effects as great as those feared by the Court in the expropriation context. ${ }^{194}$

193. Cuba's action in Dunhill can be viewed as the repudiation of an equitable obligation, although it can also be characterized as a seizure of the pre-intervention accounts receivable. In French v. Banco Nacional de Cuba, 23 N.Y.2d 46, 242 N.E.2d 704, 295 N.Y.S.2d 433 (1968), act of state was applied to Cuba's exchange control regulations where those regulations effectively repudiated an agreement guaranteeing to plaintiff the right to repatriate the earnings from certain investments. Holzer v. Deutsche ReichsbahnGesellschaft, 277 N.Y. 474, 14 N.E.2d 798 (1938), involved the repudiation of a private contract by reason of the Nazi racial laws, while Dougherty v. Equitable Life Assurance Soc'y, 226 N.Y. 71, 193 N.E. 897 (1934), involved a Soviet decree terminating all benefits under private insurance contracts.

194. The related question of the doctrine's applicability to foreign revenue measures raises its own distinctive problems. Traditionally, American courts have refused to enforce foreigu revenue laws. See, e.g., Banco de Brasil, S.A. v. A.C. Israel Commodity Co., 12 N.Y.2d 371, 190 N.E.2d 235, 239 N.Y.S.2d 872 (1963); Philadelphia v. Colıen, 11 N.Y.2d 401, 184 N.Y. 167, 230 N.Y.S.2d 188 (1962); Colorado v Harbeck, 232 N.Y. 71, 133 N.E. 357 (1921); In re Estate of Jandorf, 41 Misc. 2d 712, 246 N.Y.S.2d 378 (Sur. Ct. 1964); In re Robinson's Estate, 206 N.Y.S.2d 459 (Sur. Ct. 1960). State courts are slowly abandoning the rule as applied to the revenue laws of sister states. See, e.g., Buckley v. Huston, 60 N.J. 472, 291 A.2d 129 (1972); Nelson v. Minnesota Income Tax Div., 429 P.2d 324 (Wyo. 1967). A number of states have enacted reciprocity statutes applicable to such laws. E.g., ARK. Stat. \$ 84-4018 (1947); Kan. STAT. ANN. § 79-2910a (1969). Nonetheless, the rule as applied to foreign countries' revenue laws is arguably more essential today than in the past. Cf. Moore v. Mitchell, 30 F.2d 600 (2d Cir. 1929) (L. Hand, J., concurring). The argument for the traditional rule rests upon considerations very similar to those underlying the act of state doctrine. Yet the rule is genuinely one of non-enforcement. It requires a court to do no more than grant the taxpayer's motion to dismiss a foreign government's claim. This is not necessarily the case with act of state. See note 251 infra. The appropriate relationship between the traditional rule and the act of state doctrine poses an interesting and intricate question lying beyond the purview of this Article. On the enforcement of foreign revenue laws see Leflar, Extrastate Enforcement of Penal and Governmental Claims, 46 
At the same time this disavowal of a formalistic limitation does require that some other, perhaps arbitrary, limit be imposed upon the inquiry. Accordingly, the analysis is confined to foreign state acts involving some form of deprivation of property rights that gives rise to a claim of right to property itself (e.g., Sabbatino), or to a claim for damages (e.g., Citibank). Furthermore, our chief concern is with claims predicated upon a violation of international law, although municipal law (e.g., Dunhill) calmot be wholly ignored.

In working within these bounds, the analysis rejects any suggestion that in contrast to expropriatory acts, the regulatory and contractual actions of States are all automatically exempt from international legal control. It rejects especially the notion that all such acts, or even broad categories of such acts, are non-confiscatory. There is, of course, authority for such ideas. But they are often so devoid of economic rationality as to be nothing more than a means of avoiding embarrassments to the strict non-discriminatory, full, prompt and adequate compensation standard. ${ }^{195}$ If the rules differ according to the form of deprivation, as they do, that is usually because national behavior differs, not because one form is less a deprivation than the other. More

HARv. L. REv. 193 (1932); on the relationship of the revenue rule to act of state see Cohen, Nonenforcement of Foreign Tax Laws and the Act of State Doctrine: A Conflict in Judicial Foreign Policy, 11 HARv. INT'L LJ. 1 (1970). With respect to the traditional rule denying enforcement to foreign penal laws, see notes 263-70 infra and accompanying text. While the traditional rule regarding foreign revenue laws has its origins in the penal law rule, they may bear a quite different relationship to act of state. See note 272 infra.

195. See M. Whiteman, supra note 47, at 1143; Restatement (Second) of Foreign Relations Law of United States § 187 (1965). Compare Judge Keating's somewhat flawed but nevertheless realistic effort to come to grips with the Cuban exchange control regulations involved in French v. Banco Nacional de Cuba, 23 N.Y.2d 46, 7693, 242 N.E.2d 704, 723-34, 295 N.Y.S.2d 433, 450-61 (1968) (Keating, J., dissenting), with the following statement of Mann, quoted by Judge Fuld in the same case:

A legislator who reduces rates of interest or renders agreements invalid or incapable of being performed or prohibits exports, or renders performance more expensive by the imposition of taxes or tariffs does not take property. Nor does he take property if he depreciates currency or prohibits payment in foreign currency or abrogates gold clauses. Expectations relating to the continuing intrinsic value of all currency or contractual terms such as the gold clauses are, like favorable business conditions and good will, "transient circumstances, subject to change," and suffer from [the] "congenital imfirmity" that they may be changed by the competent legislator. They are not property, their change is not deprivation. Mann, Money in Public International Law, 96 RECUEIL DEs COURS 1, 90 (1959).

Stuff and nonsense! It only brings contempt upon international law and its scholarly purveyors. Ask the man who has suffered. And if the expectation of a governmental deprivation is the test of governmental regularity, then in light of the contemporary record there can be no rule prohibiting expropriations. If the behavior of nations cannot be reconciled with a particular norm, then the latter must be changed; it will not do to distinguish the behavior by ignoring economic reality. 
importantly, if the American courts are to act in a way conducive to the development of more adequate norms in this under-developed area of international law, they cannot retreat behind formalities that defy rational exposition, especially since their own law has at least begun to see through such devices. ${ }^{196}$

\section{Of Encroachment on the Political Realm}

Consider first the Cuban situation had the Castro government issued the sweeping July, 1960 decree, but had the United States, for its own reasons, not demed Cuban sugar access to the American

196. By an older tradition, an otherwise valid although confiscatory state police power regulation-compelling a person to use or not use property in a specific fashion at a financial sacrifice-was thought to be distinct from the eminent domain power (taking in the literal sense of title) and wholly immune from any compensation requirement. See Pennsylvania Coal Co. v. Mahon, 260 U.S. 393, 416 (1922) (Brandeis, J., dissenting). In the case of federal regulations, while the degree of deprivation was undoubtedly relevant under a substantive due process inquiry, adherence to literal notions of a taking for use foreclosed resort to the fifth amendment's takings clause.

Pennsylvania Coal Co., however, may be said to mark the end of any strict adherence to the older tradition. There a state's otherwise valid "police power" prohibition on certain mining operations was struck down. The due process clause, informed, as Justice Holmes said, by the fifth amendment's takings clause, required that while "property may be regulated to a certain extent, if regulation goes too far it will be recognized as a taking" and the state compelled to resort to the eminent domain power and to make compensation. Id. at 415.

The older tradition has, nevertheless, died hard. United States v. Central Eureka Mining Co., 357 U.S. 155 (1958), is illustrative. There Jnstice Burton took comfort in the fact it was a "war power regulation" he was dealing with in upholding the War Production Board's closure of gold mines to save equipment and divert miners to more essential work. Id. at 181. This evoked from Justice Harlan a vigorous dissent against "permitting formalities to obscure actualities" merely because the government "proceeds by indirection, and accomplishes by regulation what is the equivalent of outright physical seizure of private property." Id. at 184 (Harlan, J., dissenting).

If Eureka can be said to stand with the older tradition, that is only a matter of degree; the deprivation was virtually total. For it is clear that in spite of Pennsylvania Coal Co., the law has not arrived at the point where an equivalence in the measure of deprivation alone, if less than total, will secure for a regulation the same fate as an outright expropriation. Or conversely, it might be thought that if form were no guaranty against having to pay just compensation, form should offer no guaranty that compensation will be required; that if the governinent might regulate without paying compensation, it would not be barred from achieving an identical purpose through outright confiscation. Bnt neither symmetry nor even rationality is always controlling. This may be because in our ideas of what is just, there is much that breeds ambivalence towards the rights of private property. Here we need only note that while the government may do by uncompensated regulation what it may not do by a formal taking without compensation, the line between the two is not a firm one. The regulatory form is no longer unconstrained by the just compensation reqnirement, and the Court's application of that requirement to regulatory action does have probative value for our subject. 
market. In this context, an adjudication invalidating that decree would have been an open invitation to a series of attachments tantamount to a judicial withdrawal of the sugar quota. Far from being a claim by a handful of investors attaching an isolated piece of property, the case would have taken on a wholly different aspect. Cuba's dependence upon its sugar exports, the historical significance of the United States as a Cuban market, the place of the expropriations in the nationalistic and ideological aims of the Cuban government, all suggest an action the impact of which could scarcely be more fundamental to the relationship between the two nations. Certainly the sweeping confiscations with which Cuba answered the quota withdrawal are a measure of the potential importance of such a step. Arguably, it would rank as no less central to specifying the quality of the relationship between the two countries and to conditioning all questions of policy which might follow, than would a legislative refusal to execute a treaty or a denial of a foreigu claim to contested territory.

This sense of the largeness of the subject is complemented by a concern for the competence of the courts to resolve the questions inherent in the invitation to take such a step. The refusal of the political departments to ban Cuban imports would have implied a certain "disavowal," as Justice Douglas called it in United States v. Pink, ${ }^{107}$ of concern with Castro's decrees-not a disavowal of all concern, but a matter of proportion. It would have been a disavowal of the degree of concern necessary to warrant the kind of unilateral action that the court was being asked to take. As such it would, beyond doubt, have constituted a statement of the national interest. Unless a court, therefore, were prepared to assert its superior competence to weigh the complex and subtle considerations of economic advantage, political and diplomatic influence and military power upon which such statements hinge, it would have had further cause to question its authority to judge the foreign government's actions.

The situations most likely to pose a danger of judicial encroachment upon the political realm are major expropriations by the nation's principal trading partners, particularly nations that are important sources of petroleum and other raw materials vital in the American economy today. It is not difficult to perceive why any political decision to impose a trade ban in such cases is likely to be attended with consequences sufficient to warn agamst a judicial decision which might

197. 315 U.S. 203, 232 (1942). 
have a comparable effect. ${ }^{198}$ The record of the difficulties encountered by the State Department in the Libyan Oil cases serves to illustrate the point, ${ }^{100}$ suggesting that the Legal Adviser's willingness to see Sabbatino overruled was ill-advised at best.

Other situations may arise, however, where a judicially imposed ban might be preferable to legislative and executive sanctions. And so long as this can be accomplished consistently with the several purposes of the act of state doctrine, the characterization of the case as posing a political question will not, it is submitted, foreclose such use of the judicial power. ${ }^{200}$ There may, indeed, be a place for the Bern-

198. The relationship between expropriations of this type and the question of when the judicial power might properly be employed to deter or ameliorate foreign expropriatory excesses is worthy of note. It can be assumed that if their claims were vindicated by the courts, expropriated investors as a group would not obtain significant redress directly through the attachment of imports as they arrived in this country. The imports would simply stop arriving. As a group, their interest in judicial action is principally a matter of exerting economic leverage upon the foreign government to modify its plans, reverse itself entirely or negotiate a more adequate settlement. If one is dealing with an expropriatory program with a high ideological content, the larger the taking the less chance of judicial action having the desired effect. But generally, the larger the policy implications of judicial action the greater the economic leverage and hence the greater the chance of judicial action succeeding in these ameliorative or deterrent purposes. If, however, the political departments are observed refusing to ban imports in spite of the prospect that such action may aid the investors' cause, it must mean that there are other interests of the nation at stake, and that such of the latter as would be sacrificed to that success or hurt by failing in the attempt command the greater weight. The stronger the case for a trade ban, in other words, the greater the countervailing national interest implicit in the political departments' refusal to impose the ban. This means that the clearer the prospect of the courts effectively assisting expropriated investors as a group, the more clearly political department inaction stands as a warning against attempting such assistance. Obviously, investors may not agree with the political departments. But the judges must, unless they are prepared to assert their superior competence in the premises.

199. See Department of State, Statement on "Hot" Libyan Oil, 13 INT'L Legal MATERUALS 767 (1974).

200. In principle, whenever the elements of a political question are drawn into a decision under the act of state doctrine, any assessment of the largeness of the subject is a matter of assessing the impact of judicial action upon the nation's foreign and domestic policies. Plainly, the courts can be aided in this perceptual task by the political departments. Even if, as Justice Brennan urged, the Executive could not by mere stipulation change a non-justiciable controversy into a cognizable claim, an expression of its position might well change the judicial perception of the controversy. What might without guidance be thought political may, with guidance, be no longer viewed as such. And if the political departments perceive no harm to policy, then possibly the courts are as constitutionally bound to recognize that perception as they are constitutionally bound to avoid disrupting policy when guidance is not forthcoming. As a corollary, when the perceived largeness of the question changes, then the overall balance among the elements of a political question would appear to change. The less momentous the issue, the freer the court may be to invoke novel principles or to undertake the task of reconciling conflicting and ambiguous principles. 
stein exception. ${ }^{201}$

\section{Of Encroachments on the Settlement of Disputes}

Cases will, of course, frequently arise where neither the magnitude of American claims nor the size of the foreign government's trade and financial relationships with the United States poses a danger of thrusting the courts into that high policy-n1aking role that would have occurred under our variant of the Cuban setting. Nevertheless, even as the context moves away fron this nore obvious, constitutionally proscribed area, the other variables renlain. The foreign government's action nray still relate to American and other alien interests which

None of this, however, implies acceptance of Justice Rehnquist's deference theory. National policy is not the only interest to be protected. Certainly, in the context of Citibank and Dunhill, protection of the other affected claimants was not a matter upon which the Executive could control the Court. Moreover, nothing that the political departments say can control what the courts, in the name of their own integrity, determine to be the applicable rule for their decision. See note 256 infra. What this means, of course, is that if the political departments by their guidance can change a political question into a coguizable controversy, it must be guidance issued with full knowledge of all possible outcomes. Citibank is illustrative. One cannot read into either the Legal Adviser's letter or the Hickenlooper/Sabbatino amendment acceptance of a judgment impliedly invalidating all peacetime seizures under the Trading with the Enemy Act, including the Cuban Assets Control Regulations. And certainly neither can be read as accepting an international standard which, should it validate Cuba's decrees, would cast doubt upon the whole course of American policy toward Cuba. Neither letter nor statute, in other words, was accompanied by the recessary evidence demonstrating a consideration of the foreign policy interests at stake in the case. See Sabbatino, 376 U.S. at 436. Until that evidence was supplied the Court was bound to ignore both. And while there may be a place for a new cooperative regime between the political and judicial branches, that regime bears no resemblance to Justice Rehnquist's notion of judicial deference to the Executive.

Focusing more specifically on the question of a judicially imposed trade ban, it would seem from this analysis that if the Executive stated that the consequences of an adjudication upon the relationship of the two countries were not as adverse as our discussion of the Cuban variant suggests, see Part IV. B.2, then the court migbt well hear the challenge to the foreign government's actions. Additionally, if, notwithstanding those consequences, the Executive advised that a judicially rather than politically imposed trade ban would better serve the national interest (i.e., that the national interest determination implicit in political inaction was not as the court must otherwise assume), then it would again seem that the challenge should be heard. There are, however, two limitations to be observed. First, the Executive advice, as trigger to the imposition of a trade ban, would probably have to rest upon a grant of legislative authority. And, in both situations, the courts could act upon such advice only if assured that the political departments would accept the consequences of using the legal standards hereinafter discussed. See Part V. B. infra.

201. See Bernstein v. N.V. Nederlandsche-Amerikaansche Stoomvart-Maatschappij, 210 F.2d 375 (2d Cir. 1954). The court held itself relieved of the act of state doctrine's proscription when advised by the State Department that an adjudication would not be contrary to the foreign policy interests of the U.S. 
occupy a highly visible place in its economic affairs. The political power of those interests, real or imagined, may be significant. The act may be associated with the government's larger international economic objectives, or it may be undergirded by a strong ideological imperative.

In this setting the several elements in the Sabbatino formula have a differential impact. An adjudication, even if not impinging upon high pohicy, could have political and symbolic effects prejudicial to the general redress of American grievances and embarrassing to the nation's wider economic and political interests. Yet, because the possibilities of frustrating the foreign government's purposes are limited, such embarrassments are by no means certain to attend every controversy and are arguably a matter to be judged on a case by case basis, with Executive assistance. Indeed, if the foreign government has actually violated international norms, the responsibility of the American courts to uphold those norms should not be set aside without a clear showing of necessity in the particular case. It is a setting, in other words, where Justice Harlan's broad interdiction may be seriously challenged so long as justice to the American investors immediately involved and a concern for national policy are the only touchstones to the act of state doctrine. Perhaps one can read some such sense into Justice Powell's position, and it certainly accords with Justice White's vigorous appeal for a more selective approach. ${ }^{202}$

There remains, however, a concern for the integrity of the judiciary itself. The controlling analogy is the Citibank analysis-an analogy which also applies to our variant on the Cuban setting and bolsters the constitutional predicates already observed in that instance. While the argument is fully developed in Part V, suffice it to say here that substantial questions exist as to whether, in a similar setting, the courts of the Umited States would hold the United States government to a constitutional standard comparable to the traditional non-discrinmatory, full, prompt and adequate compensation standard of international law. Yet that standard performs a critical facilitative function in the settlement of international investment disputes. In cases, therefore, where the courts, in the name of their own integrity, could not uphold that standard, their intervention would serve neither the cause of justice nor the "rule of law" among nations. Few more pointed examples can be found demonstrating that the progress of law among nations caumot invariably be equated with the judicial enforcement of international norms, and that act of state may indeed serve to secure the efficacy of those norms in their proper role.

202. See Sabbatino, 376 U.S. at 466 (White, J., dissenting). Note also the Justice's proposal that the courts notify the State Department and then decline to exercise their 


\section{Of What Remains}

Lastly, it is possible to anticipate a potentially large number of cases where there is no danger of intruding the courts into the political realm and no risk of undermining judicial integrity, cases where the courts can be assured of applying a single standard evenhandedly under both constitutional and international precept. The problem lies in discerning the case. To determine whether or not to sit in judgment on a foreign act-to decide whether act of state should apply-may actually require judging that act. Any decision, in other words, even one applying traditional norms, inay result in pronouncements as destructive of those norms as an outright disavowal of them would be. The question is whether these dangers can be avoided. Can the courts, if sensitive to the problem, clear in understanding the conflict to be avoided, and careful in articulating their results, intrude themselves into these cases as a positive force for justice and order in the international sphere? An affirmative answer is devoutly to be desired. But on close examination the risk, it would seem, is not worth the undertaking. Justice Harlan's broad interdiction was, indeed, a wise extension of prior authority.

\section{THE WIDER UsES OF THE DOCTRINE}

Once the analysis leaves the more certain confines of the Cuban cases where Sardino supplies the controlling constitutional analogy, the task of comparing constitutional with international precept becomes a lrazardous task indeed. What is offered here can hardly be an exhaustive review of American law. Nevertheless, there are two recurring lines of authority sanctioning the deprivation of property in spite of the fifth amendment's due process and takings clauses, neither of which can be ignored in any serious discussion of the act of state doctrine. There is more than enough to suggest that both may be rooted in concerns not unlike those that underlie the political question doctrine.

\section{A. Constitutional Practice}

\section{A Normative Dimension}

The Court has inany times reminded us that the fifth amendinent's takings clause is an ethical injunction. ${ }^{203}$ Beyond this there may be,

power only upon receipt of a request for withdrawal from the Department. Id. at 46870.

203. See, e.g., United States v. Commodities Trading Corp., 339 U.S. 121, 124 (1950); United States v. Dickinson, 331 U.S. 745, 748 (1947). As an ethical injunction 
as Justice Jackson seems to have suggested, a certain open-ended utilitarianism about it as well. ${ }^{204}$ Nevertheless, in searching for normative specifications of somewhat greater rigor, the idea that compensation is sometimes required may be usefully thought of as resting upon an assumed relationship between collective action and individual welfare. It assumes that a primcipal impulse and justification for organized society is the promise that there are gains to individual welfare which might not otherwise be secured without collective action. It also assumes that any collectively compelled change in the distribution of resources can meet its promise to private welfare only if the gains to individuals from the compelled new use are great enough to permit compensation for the losses imposed by a denial of the old, that is, only if the "gainers" are willing and able to pay off the "losers." Social, psychological and even aesthetic gaims are no less a part of this welfare calculus than material gains. Stated another way, if a violation of the literal terms of the just compensation requirement is capable of evoking outrage, this is only the outward manifestation of a conviction that collective action, having failed to pay for what it imtended to achieve, has failed in that promise to individual welfare which stands as the principal justification for such action.

Added to this, there has been forged a critical imstrumental link between the just compensation requirement and private nuarkets. Where compensation is required in the name of justice, market value is the measure of justice done. Using this basic nornative benchunark, we turn to two important lines of doctrine.

\section{Of Magnitude and Comprehensiveness}

It is axiomatic, as already noted, ${ }^{205}$ that a strong formalistic tradition continues to persist in American law. The government can deprive a person of property by regulation even though to take the same value for the same purpose would require just compensation. The taking of $10 \%$ of the value of property by regulating its use is

the provision may be an enigma: "The political ethics reflected in the Fifth Amendment reject confiscation as a measure of justice . . . But the Amendment does not cortain any definite standards of fairness . . . " United States v. Cors, 337 U.S. 325, 332 (1949) (Douglas, J.).

204. "The Fifth Amendment," Justice Jackson said, "undertakes to redistribute certain economic losses inflicted by public improvements so that they will fall upon the public rather than wholly upon those who happen to lie in the path of the project. It does not undertake, however, to socialize all losses . . . ." It does so only for those "which have the law back of them." United States v. Willow River Power Co., 324 U.S. 499, 502 (1945).

205. See note 196 supra. 
not invariably equated with taking $10 \%$ of the property itself. Nevertheless, the line between the two is not a firm one. The regulatory form is no longer wholly unconstrained by the just compensation requirement, and the Court's application of that requirement to regulatory action does have probative value for our subject.

Given the breakdown of these formalistic distinctions, it is instructive to look at the taxing power. Plainly, this power is an exception to the ethical assumptions which we have ascribed to the fifth amendment's coinpensation requireinent. Formal taxation (i.e., excluding taxation through inflation) is the method sanctioned by the Constitution for having society as a whole pay for the gams to social welfare incident to all other forms of governmentally compelled changes in the use of resources. Yet, when so used, the tax law has a redistributive effect, quite apart froin its use as an instruinent for the deliberate redistribution of wealth within society. What this then means is that if the government taxes to meet a social exigency, such as controlling inflation or fighting a war or reforming the currency, these redistributive effects are, and inust be, basically iguored. Yet obviously there coines a point where regulations, expropriations, and contract repudiations to the same end (e.g., wage and price controls, war production controls, and gold clause abrogations) can have, in magnitude and comprehensiveness, an effect not very different from taxation. That such measures have redistributive effects (i.e., are confiscatory) ${ }^{206}$ is a matter that rationally should be ignored so long as the comparable effects of the tax law are ignored. To grant the government the power to regulate or take without coinpensation in these instances stands as little more than a pragmatic grant of permission to do by regulation essentially what it might do by taxation, especially if it is thought that the regulatory form will accoinplish the governmental purpose more effectively.

The point should be inade plain. The author has found no authority explicitly sanctioning such a rationale for a regulatory or expropriatory deprivation of property. But the interest here is in the strength of the underlying values. Thus, it should be recognized that all uncompensated expropriations and many, if not most, regulations redistribute wealth in society. Indeed, some regulations, such as wage and price controls, could not otherwise achieve their purpose: namely, controlling explicit money prices, not necessarily real prices. In these instances, to say that the Constitution requires cornpensation is tantanoount to saymg that the Constitution denies the power to regulate. Hence, the point. In the usual case there may be important differences

206. See note 96 supra regarding the use of the word "confiscation." 
in the redistributive effects (who gains and who loses, how inuch and in what form) between general taxation and other forms of deprivation. Generally, taxation may be a more objective and rehable way of distributing the costs of securing the general welfare. But there would be something profoundly irrational in a constitutional scheme that granted the power to achieve a social purpose requiring the redistribution of wealth so long as taxation was used but would deny a power to regulate or expropriate without compensation for the same purpose, if, by some general test of magnitude and comprehensiveness, the redistributive effects were not likely to be very different. In such a context, the only interesting constitutional question concerns the content of that general test.

Here, cases such as United States v. Central Eureka Mining ${ }^{207}$ and the "Gold Clause"208 cases are on point. Not only do they illustrate the use of such a test, they also illustrate some of the difficulties attending its application to specific cases and the imprudence of maintaining any formalistic distinction that would treat the expropriatory form of deprivation more strictly than other forms.

In Eureka, Justice Burton, writing for the majority, upheld the government's decision to close the nation's gold mines in order to divert men and equipment to more essential wartime needs. Initially taking comfort in the regulatory form of the government's action, he then sought to equate that regulation with the wider wartime price and production controls which the Court on several occasions had already validated. ${ }^{209}$ After objecting to the triumph of form over substance, ${ }^{210}$ Justice Harlan responded in dissent not by denying that wartime regulations may fall outside the constitutional demand of just compensation in soine mstances, but by denying that the regulation of the gold mines was such an instance. The wartime price and production control cases were, he said, "wide of the mark," because, inter alia:

In all of them the Government was administering a nationwide regulatory system rather than a narrowly confined order directed to a small, singled-out category of individual concerns .... In those cases the Court was rightfully reluctant to sanction compensation for losses resulting from wartime regulatory measures which, under conditions

207. 357 U.S. 155 (1958).

208. Norman v. Baltimore \& O.R.R., 294 U.S. 240 (1935), and Perry v. United States, 294 U.S. 330 (1935), are the cases of principal interest.

209. 357 U.S. at 168, citing Hamilton v. Kentucky Distilleries \& Warehouse Co., 251 U.S. 146 (1919); Jacob Ruppert v. Caffey, 251 U.S. 264 (1919); Bowles v. Willingham, 321 U.S. 503 (1944); United States v. Caltex, 344 U.S. 149 (1952).

210. See note 196 supra. 
of total mobilization, have ramifications touching everyone in one degree or another. ${ }^{211}$

Possibly war was an essential element in Justice Harlan's view of the case, but plainly that was not enough. ${ }^{212}$ Only if sufficiently generalized in its impact upon society could even wartime confiscatory regulation be sanctioned. That poimt had not, in the Justice's view, been reached in Eureka. Moreover, it should not be forgotten that the Justice was adamant in equating the government's regulatory acts with a taking for use. Does this suggest he would apply his tests of magnitude and comprehensiveness to uphold an outright expropriation without compensation which otherwise qualified as a taking? Perhaps not, but the mere possibility is certainly illustrative of the difficulty in maintaining the formalistic line.

If Justice Harlan's reasoning in Eureka owed something to the wartime context of the case, the "Gold Clause" cases can in considerable part be read as a peacetime analog. When in 1933 and 1934 Congress and the President demonetized gold and devalued the dollar (reduced the gold parity) ${ }^{213}$ they demanded surrender of all outstanding gold coin and bullion, prohibited domestic trading and exportation of gold ${ }^{214}$ and also abrogated all "gold clauses" in public and private obhigations ${ }^{215}$ (i.e., clauses calling for payment in gold coin of a specified weight and fimeness or in other legal tender equivalent in value to the specified coin).

In Norman v. Baltimore \& Ohio Railroad Co., ${ }^{216}$ the Court dealt with the clauses in local governmental and private obligations. Those clauses, Chief Justice Hughes held, called for payment in money, not in a commodity. Since Congress was constitutionally authorized to "coin money" and "regulate the value thereof," 217 the abrogation of the clauses was a necessary incident of that power, and hence, not offensive to the fifth amendment. To deny abrogation in the face of devaluation would mean that while the income of debtors was "controlled by

211. 357 U.S. at $182-84$.

212. Justice Harlan also suggested a distinction between regulations which destroy all profitable use of property and regulations which leave the owner with something of value. Id. at 182. Here is Justice Holmes' notion of regulation going "too far." See note 196 supra.

213. Gold Reserve Act of 1934, 12 U.S.C. $\$ \$ 411$ et seq. (1970).

214. Emergency Banking Act, Act of March 9, 1933, ch. 1, 48 Stat. 1; Executive Orders Relating to the Hoarding, Export, and Earmarking of Gold Coin, Gold Bullion, and Gold Certificates, 31 C.F.R. $\$ \S 50.1$ et seq. (1939).

215. Joint Resolution of June 5, 1933, ch. 48, 48 Stat. 112.

216. 294 U.S. 240 (1935).

217. U.S. CoNST. art. I, $\$ 8, \mathrm{cl} .5$. 
law, their indebtedness" would have to be "inet by an amount of currency determined by the former gold standard." Having noted the estimate of $\$ 75$ billion of such obligations outstanding with annual interest costs of \$3-4 billion, the Chief Justice stated:

It requires no acute analysis or profound economic inquiry to disclose the dislocation of the domestic economy which would be caused by such a disparity of conditions in which, it is insisted, those debtors under gold clauses should be required to pay one dollar and sixty-nine cents in currency while respectively receiving their taxes, rates, charges and prices on the basis of one dollar of that currency. ${ }^{218}$

In Perry v. United States, ${ }^{219}$ the Court turned to the clauses in the federal government's own obligations. There, the Chief Justice found that while Congress had the power to regulate the value of inoney, it had, in borrowing, promised that the lender should not suffer "through a depreciation in the medium of payment" occasioned by the exercise of that power. Abrogation in that case, the Chief Justice said, "would be not the practice of economy, but an act of repudiation."220

Having so firmly aligned the Court on the side of contractual integrity, it might have been expected that plaintiff would win his cause. But not so, for the Court next turned to the ineasure of damages. Plaintiff's claim was for $\$ 16,931.25$ on a $\$ 10,000$ bond. At this ratio, the Government brief had pointed out, enforcement of the clauses would have increased the $\$ 20$ billion Government debt to $\$ 34$ billion and the annual interest expense from $\$ 700$ million to $\$ 1.2$ billion. ${ }^{221}$ In light of the policy of balancing the federal budget which prevailed at the time, these increases would have been nothing short of catastrophic. The President, according to the New York Times, was

218. 294 U.S, at 315-16. It has been suggested that the decision in Norman may rest upon the uniqueness of the power to regulate the currency. See Dunham, Griggs v. Allegheny County In Perspective: Thirty Years of Supreme Court Expropriation Law, 1962 Sup. CT. Rev. 63, 77. If so, it is not immediately apparent why one unay not effectively contract with others to be protected against such regulation, except as such contracts by their number and dollar magnitude might have the practical effect of constraining the government in its use of the regulatory power. Moreover, it is unclear why the power to regulate the currency is different from any other governmental regulation issued in the effort to recover from a depression or in response to other large public exigencies.

219. 294 U.S. 330 (1935).

220. Id. at 352-53. This would appear to distinguish Perry from Nortz v. United States, 294 U.S. 317 (1935), where the gold certificates involved were not thought to have been issued or purchased with the broader purpose in unind of protecting the holder against the subsequent depreciation of the currency.

221. See A. Nussbaum, Money In the LaW 364 (1939). 
prepared to tell the people that compliance was impossible. ${ }^{222}$ Against this background the Court held that because Congress was fully empowered to bar trading in gold, the failure to pay in gold coin gave rise to no cognizable injury. ${ }^{223}$ Moreover, under a "gold-value" clause, plaintiff's injury was not to be measured by the equivalent of the gold coins promised. He was not to receive the difference in the official value of the dollar before and after the devaluations even though, as the Court had held, it was against such changes that he had contracted to be protected. Rather, his damages were to be measured by the loss of purchasing power that would have resulted from a failure to pay at the contracted higher value. Not only was there no proof of such loss in the case, but given the general decline in prices since the date of purchase, such proof might have been very difficult to inake. Plaintiff was entitled, in short, to only the $\$ 10,000$ face anount of the bond.224 As Nussbaum has observed, the Court, by its theory of the measure of compensation, essentially nullified its holding on the right to compensation. ${ }^{225}$

Justice Stone's concurring opinion highlights the point: The Justice agreed with the majority that the clause in question iniplied a promise that the holder would not suffer from a later depreciation in the currency. But he was unwilling to say that this obligation overrode the power to regulate the currency, that there was a distinction between the federal government and other debtors. To hold otherwise would have ineant, he suggested, that the Government might so manage the borrowing power (i.e., incur such large gold-value obliga-

222. New York Times, Feb. 21, 1935, at 1, col. 6.

223. 294 U.S. at $355-56$.

224. Id. at 357-58.

225. It is to be emphasized with respect to Perry that, as Nussbaum points out, the very purpose of a gold value clause was to protect the creditor against governmental disturbances in gold trading like those involved in that case. In other words, the creditor was to receive the equivalent in legal tender of what he would have received had he been paid in gold coin and been free to trade gold on world markets. The thought that plaintiff was claiming a windfall also is incorrect. It is true that had plaintiff been awarded the full amount of damages sought, he would have obtained much more in the way of purchasing power than he would have received had the gold value clause never been abrogated and prices remained constant. But then if he had been certain that prices would remain unchanged, he would not have been willing to pay as much for the gold value clause. The possibility of price changes precipitating changes in the value of the currency largely determined the price he was willing to pay for that clause. Moreover, it is notable that it was the competitive devaluations in the context of worldwide depressions that had largely spawned such clauses. See A. Nussbaum, supra note 221, at 365. Nussbaum's nullification theory would seem, therefore, to be entirely correct. The Government was allowed to take exactly what it had promised to give. 
tions) as to effectively impair its power to regulate the currency. ${ }^{228}$ In other words, if the burden of such contracts would have effectively defeated the attainment of a sufficiently large regulatory purpose, repudiation of the contracts was permissible. Although unwilling to adopt this position explicitly, the majority arrived at the same point.

The larger lesson of these cases is not to be denied-magnitude and comprehensiveness can play a role in determining the constitutionality of confiscatory action. If the redistributive inpact of such an action is sufficiently broad and the costs of forestalling the deprivation large enough to frustrate an important national purpose, the cases illustrate how difficult it may be for a court to interpose the Constitution against the Government. This is especially so when the latter can cite such utilitarian concerns as the adverse effects of compensation upon the inanagement of the budget or even simple efficiency in the execution of a governmental program.

Caution, however, must be exercised in drawing analogies from all of this to particular foreign deprivations of American property, particularly in the expropriatory form. The cases did not involve a total deprivation of all value, except in the case of Eureka. There still remains the matter of form, however fragile may be the distinction between regulation and contract repudiation on one hand and expropriation on the other. In addition, there is the problein of a confiscation that discriminates against aliens rather than falling more randomly across the society.

On the other hand, because our interest is in the nature and strength of underlying values, especially the extent to which a cominunity of values nay be thought to exist between American constitutional law and a strict view of the traditional international law, the decisions are imstructive. From the standpoint of our values, is there any difference, for example, between a total deprivation and a less than total loss whicli nevertheless destroys all the value expectations upon which the acquisition of property was predicated, as in the "Gold Clause" cases? If not, what is the measure of deprivation that distinguishes the impermissible (confiscatory) froin the permissible (non-confiscatory) deprivation? Or rather, is not the very fact of resort to such elusive phrases evidence of a fundamental ambivalence towards the rights of private property? If in the practice of such ambivalence considerations of magnitude, comprehensiveness and essentiality of pur-

226. 294 U.S. at 358 (Stone, J., concurring); see Dawson, The Gold Clause Decisions, 33 MrCH. L. REv. 647, 656 (1935). 
pose play a role, must we not entertain the possibility that a total deprivation might receive constitutional sanction? Moreover, again as a reflection of American values, is it not immaterial that such a deprivation might be permitted by the Court only if it took the form of a regulation or the repudiation of a contract? Particularly in judging the acts of less developed countries, it would seem necessary to recognize that the use of the expropriatory form is often dictated more by considerations of institutional competence than anything else. And surely the non-discrimimatory character of the actions in these cases is a wholly irrelevant factor in viewing most foreign expropiatory programs through a constitutional lens. ${ }^{227}$

Stating the point another way, there would seem to be more than passimg affinity between the reasoning in Eureka and Norman, the results in Perry, and the views expressed by Mexico three years later, in response to a demand by Secretary of State Cordell Hull that American landowners be accorded full, prompt and adequate compensation for properties taken by the Mexican government under its land reform programs. In international law, the Mexican Foreign Mimister asserted, there was "no rule universally accepted in theory nor carried out in practice" requiring either immediate or deferred compensation for "expropriations of a general and impersonal character" such as those carried out by Mexico. ${ }^{228}$ Otherwise, the Foreign Minister argued, "a transformation of the country, that is to say, the future of the nation, [would] be halted by the impossibihty of paying immediately the value of the properties" taken. ${ }^{229}$

\section{Of "Evils To Be Eradicated"}

The second doctrinal line of interest is the so-called "evils (or harms) to be eradicated/causality" test originating in due process chal-

227. In the matter of discrimination, were the bondholders in Norman and Perry any less discriminated against than aliens, including Americans, might be in the case of a foreign expropriation? The use of a non-discrimination test to distinguish bondholders from aliens-to protect aliens but not bondholders because the deprivation in the case of bond repudiation falls indiscriminately upon both citizens and aliens-begs the question. Discrimination against aliens goes to the purpose of the confiscation. To impose a non-discriminatory qualification on the magnitudinal test is merely to say that a nation may confiscate in order to conduct a war or devalue the currency, but not to forestall the perceived threat to national economic and political independence posed by what is thought to be a too-extensive foreign ownership of national resources. Apart from the inherent improbability of such a rule, it is a quite inapposite qualification upon the magnitudinal test. For a broader discussion of the non-discriminatory criterion in international law see Dawson \& Weston, supra note 108, at 87-91.

228. 3 G. HACKWORTH, supra note 99 , at 657 .

229. Id. at 658 . 
lenges to state police power regulations. ${ }^{230}$ Properly understood, the test appears initially as a further and distinctive effort to limit what Justice Holmes was prone to call the "petty larceny" of the police power. ${ }^{231}$ Perhaps because the test of whether a regulation had gone too far was so nebulous, calling for a case-by-case weighing of public desire against private cost, ${ }^{232}$ the addition of a requirement that the regulation also be directed, in both purpose and degree of deprivation, at eradicating a public harm caused by the private owner of property appeared to offer a welcome element of objectivity.

Professor Dunham has quite elegantly drawn the principle out of a wide range of cases. ${ }^{233}$ Here a few decisions will suffice to illustrate. In Nashville, Chicago \& St. Louis Railway Co. v. Walters, ${ }^{234}$ Justice Brandeis, acknowledging that the police power may appropriately be used to secure gains to public welfare and convenience-in that case a grade separation where a railroad crossed a public way-also insisted that the cost of those gains (an assessment) not be imposed on a single individual unless the iniposition bore "soine reasonable relationship to the ... advantages to be secured" by that person or "to the evils to be eradicated."235 Thus, the Suprene Court of Tennessee's refusal to inquire into such matters as the relative responsiblity of railroad and highway users for accidents was reversible error. In Atchison, Topeka \& Santa Fe Railway v. Public Utilities Commission ${ }^{238}$ an assessment for the construction of a grade separation was upheld because "the presence of the tracks in the streets create[d] the burden [of the construction] in the interest of public safety and convenience," while in Panhandle Eastern Pipeline Co. v. State Highway Commission ${ }^{237}$ the absence of public danger froin a gas transnission line to be crossed by a new public highway invalidated the state's demand that the pipeline owners relocate the line. In Goldblatt v. Town of Hempstead, ${ }^{238}$ Justice Clark, in spite of deficiencies in the record, inferred that further excavations in a gravel pit 1might be "attractive and dangerous to children." He then eniphasized the absence of evidence regarding the

230. See, e.g., Nashville C. \& St. L. Ry. v. Walters, 294 U.S. 405, 429 (1935). See notes 233-50 infra and accompanying text.

231. 1 HoLMES-LASKI LeTTERS 456-57 (M. Howe ed. 1953).

232. See note 196 supra.

233. Dunham, supra note 218.

234. 294 U.S. 405 (1935).

235. Id. at 429.

236. 346 U.S. 346,353 (1953).

237. 294 U.S. 613 (1935).

238. 369 U.S. 590,595 (1962). 
losses that the owner would suffer if prohibited from further excavations in order to uphold that prohibition under a general presumption of constitutionality.

Had the use of this test been confined to state police power regulations it might not be of much interest to our subject. But it occurs elsewhere as well. Justice Harlan used it to bolster his attack on the gold mine regulations in United States $v$. Central Eureka Mining; the gold mines were not, to his mind, a "harm" to society. ${ }^{239}$ Justices Douglas and Black invoked its aid in their dissent in United States $v$. Caltex, Inc., ${ }^{240}$ wherein Caltex was denied compensation for petroleum storage facilities destroyed when the American army retreated from Manila.

Set in this larger federal context, the doctrine is of considerable significance. It no doubt evidences a judicial determination to exercise greater control over regulatory deviations from the just compensation requirement. But what is of immediate interest are the values thought to be served by selecting this particular point for drawing the line and implicitly lending a certain ethical license to deviations which meet its terms.

First, it is to be observed that none of the above cases has adopted a temporal test of causality. In Nashville, Atchison and Hempstead it was the community action-the expansion of the highways and the growth of the surrounding town-not the railroad or the gravel pit owner that, in a temporal sense, caused the asserted harm. ${ }^{241}$ This, in turn, means that the test has no deterrent or punitive purpose but serves only as a way of choosing between two incompatible claims to property: the claim of the owner to treat as his property (that bundle of benefits from which he can exclude others) the benefits derived from one set of activity (harms), and the claim of others to treat as their property the benefit of having those activities cease. Clearly, recognition of one clain excludes the other.

In this respect, the "evils to be eradicated" cases are one with Miller v. Schoene. ${ }^{242}$ There the Supreme Court sustained a Virginia

239. 357 U.S. $155,182-83$ (1958) (Harlan, J., dissenting).

240. 344 U.S. 149, $156^{\dagger}$ (1952) (Douglas, J., dissenting).

241. In Nashville, Justice Brandeis, citing a long line of authorities, was quite clear that an owner may be thought to have caused the harm to be eradicated even though the "railroad was built before the crossing was made." 294 U.S. at 430 . But this then means that the test was not thought of as serving a deterrent purpose, nor does it appear to have been a means of securing from property owners some higher order of socially responsible behavior. If supported only by a punitive purpose, it is an outrage.

242. 276 U.S. 272 (1928). 
statute requiring plaintiff to destroy, without compensation, ornamental red cedar trees infected with a cedar rust that was fatal to neighboring apple orchards but harmless to the cedar host. ${ }^{248}$ The onset of the rust compelled the state, or so the Court thought, to choose either cedar trees or apple trees-the two could not coexist. The Court concluded that when

forced to such a choice the state does not exceed its constitutional powers by deciding upon the destruction of one class of property in order to save another which, in the judgment of the legislature, is of greater value to the public. ${ }^{244}$

Plainly, cedar rust was an evil to be eradicated, but only if one wanted to grow apples. Likewise, a railroad on a public way or a gravel pit in a town were evils to be eradicated, but only if one wanted to liave a public way or a town around the gravel pit. Thus, the Court in Miller quite properly stated (as it might have in all the other cases) that the problein was choosing which use was the most valuable to the community as a whole-which use contributed most to individual welfare.

But then, why no compensation? In all the cases the legislature and the courts were being asked to respond to changes in external circumstances-the onset of cedar rust, the growth of a town, the legislative decision to build a higlwway-against the background of an existing configuration of property rights. If the Court liad merely affirmed those rights (invalidated the legislation), the full economic impact of the change in circumstances would have been borne by someone other than those who ultimately bore those costs because of the decision. The Court, in other words, made two essentially separate decisions. It validated the legislative decision to relieve the highway users, the homeowners and the apple growers from bearing the costs of safety (or lack of safety) on the highway or in the town or of protecting their apple trees. It permitted the existing configuration of property rights to be changed. By refusing to require compensation, the Court also permitted the legislature to shift those costs, not to the community as a whole, but to the railroads, and to the gravel pit and cedar tree owners, the very people protected from bearing those costs by the exist-

243. Miller emphasizes the difficulties attending the distinction between a regulatory taking and an expropriation and between confiscatory and non-confiscatory deprivations. Would the government have had to compensate if it, rather than the private owner, had destroyed the trees? Such a result would have been absurd. Did the fact that the owner could use the cut trees for lumber or firewood, save the law from being confiscatory? If so, the word loses its meaning.

244. 276 U.S. at 279. 
ing configuration of rights. Why should this be so? If the answer is that the community (i.e., the legislature) refused to pay, then the question is more fundamental. Why did the Court, as guardian of the constitutional order, abandon compensation as the acid test of whether the gains to the community from protecting highway users and apple growers actually outweighed the losses to the community from the failure to grant that protection-whether the protection actually served a public purpose? In other words, why did the Court not recognize that in its refusal to pay, the legislature's assertion of a public purpose may have simply been rhetoric signifying political capitulation to special interests at the expense of the general welfare?

The thought that an explanation may be found in the theury of externalities-that private inarkets, being incapable of internalizing all costs, overstate the value of the extant use so that the law must pay only the true value-will not do. ${ }^{245}$ Nor is it possible to evoke vague references to imperfect markets. The market is not at issue here. Such inatters as transaction costs and free-rider problems may make resort to public authority appropriate. ${ }^{246}$ They cannot, however, explain the failure to pay compensation. To explam the results as a

245. If we characterize the object as merely securing a social gain, market value compensation must be paid; if it is characterized as eliminating a harm, that measure of compensation is to be reduced. Which is it, or is it both? Even accepting the possibility that externalities do exist, the poiut is that the margin of overstated market value is at once a measure of the harm being eliminated and of the minimum benefit being derived by society from eliminating that harm. If society is unwilling to pay the private owner the margin of overstated value, then plainly we have proof, under the just compensation assumption, that the elimination of those external costs is far less valuable to society as a whole than permittiug the owner to continue with his use of the property and having society pay those costs. See generally Coase, The Problem of Social Costs, 3 J. LAW \& Econ. 1 (1960). Stated another way, the benefit the private owner derives (the added return on his investment) from not having all costs internalized is the margin required in order to keep him using his property in a way that, according to our assumptions, the community itself (by its unwillingness to pay) has said provides the greatest gains to the welfare of the whole. In short, the quarrel is with the requirement of compensation per se as a proper test of relative welfare gains and losses, and not witb market value as a measure of compensation.

246. The sheer number of homeowners, road users or apple and cedar growers, the uncertainties of determining with whom to trade, and the costs of negotiation-all may constitute "transaction costs" which raise the cost of a market solution above the value differential between the alternative resource uses. Their effect may in turn warrant governmental action (depending, however, upon the often considerable costs of such action), provided those compelled to give up their property are fully compensated. Additionally, under a free market regime, those engaged in the more valued activity will be tempted to wait for others similarly situated to buy out the less valued use (i.e., to get a "free ride" on the others). Theoretically at least, this behavioral phenomenon could produce a total standstill in the trading process. See generally R. POSNER, ECONOMIC ANALYSIS OF LAW 24-27 (1972). 
manifestation of our general reliance upon the political system to assess the general welfare begs the question. It is the purpose of constitutional principles to establish a standard of reason to which political judgments must adhere.

It is tempting to find a rational relationship between these denials of compensation and the general welfare, in the belief that the welfare of imdividuals in society as a whole can, under certain circumstances, be enhanced only by the transfer of wealth from one group within society to another. Whether such possibilities actually exist in the real world or not, it is far from clear how the highly subjective and normative concept of an evil to be eradicated is probative, in any objective, empirically refutable sense, of a condition warranting resort to such a principle.

This question is underscored by the aircraft overflight cases in which compensation was required even though, as in the cases under discussion, there was no literal taking for use. The difference in result cannot be explained by the older, formalistic tradition. In United States v. Causby ${ }^{247}$ and Griggs v. Allegheny County, ${ }^{248}$ the government was required to compensate adjacent property owners for losses in use and enjoyment suffered because of the noise, vibrations and fear of injury resulting from the wartime operation of a military airbase (Causby) and from a new airport built to handle jet traffic into Pittsburgh (Griggs). Like the "evils to be eradicated" cases, it was the government decision that in a temporal sense caused the imjury; the decision in Griggs to secure safer jet air service to Pittsburgh and in Causby the decision to train pilots for the war. Since the continued undiminished use by the owners of adjacent property would have frustrated those objectives altogether, it was an "evil" in the sense that it forestalled the realization of a public good, no less than did railroads which obstructed a safe road for travel or the gravel pit which interfered with a safe town for children. If measured by the urgency or public importance of the community use which the adjacent owners might have forestalled, this would seem clear. Certainly, there would not appear to have been any economic reason to justify a wealth transfer in one case and not in the other. If there was some discrete social objective to be served by such a transfer im the railroad and gravel pit cases, it would seem to obtain equally in the airport cases, unless it is because railroads and gravel pit owners are generally wealthier than farmers and hone-

247. 328 U.S. 256 (1946).

248. 369 U.S. 84 (1962). 
owners. ${ }^{248}$ The rhetorical device of "evils to be eradicated" is not being employed, in short, as an objective test for determining when a redistribution of wealth might be thought to enhance the general welfare.

Possibly, then, the aircraft overflight cases were just wrong; or perhaps the railroad and gravel pit decisions missed the mark. If so, our law is badly skewed. This is a possibility not to be dismissed hightly. The cases may reflect no more than our profound ambivalence towards private property, our propensity to abhor the larceny of government while insisting that soine larceny be directed at some people without any rational principles to govern precisely when this should occur.

Yet there is another view. Perhaps the cases are not to be approached as posing a problem in the rational consistency of rules, but rather as offering a lesson in the judicial use of rules as a mechanism of social control. Iromically, to decry our ambivalence toward private property as essentially arbitrary, even wasteful and destructive of incentive, may itself be arbitrary. The very persistence with which that ambivalence recurs in society serves to warn that at some point to deny the ambivalence may, by undermining the consensual underpinnings of all order, be the more arbitrary and wasteful course of action. The redistributive primciple may under proper circumstances be a selfproving proposition. And whether articulated as such or not, the test of "evils to be eradicated" and the magnitudimal test may be seen as yielding some rough sense of the cases in which a court cannot risk the possibility of such an occurrence. They may stand as crude guides to that case where the judiciary, as the least representative of our governmental institutions, must yield to the political demand for the redistribution of wealth for fear that the compensation requirement's denial of that demand may result in the very diminution in the general welfare agamst which it was otherwise intended to protect.

Viewed from this perspective, the tests may not be too far wide of the mark. Both speak in terms of public expectations. The magnitudinal test tends to measure a point where the costs of the governmental purpose (i.e., the loss of value in existing property rights) are likely to be outweighed by the costs to the basic consensual order if public expectations are frustrated. The "evils to be eradicated" test, while less readily justified, is also couched in terms of public expectations. For this purpose, forestalling a public good is too imprecise a definition

249. Compare the defense of Miller $v$. Schoene in Samuels, Interrelations Between Legal \& Economic Processes, 14 J. Law \& Econ. 435 (1971) with Buchanan, Politics, Property, and the Law: An Alternative Interpretation of Miller et al v. Schoene, $15 \mathrm{~J}$. LAW \& EcoN. 439 (1972). Neither author undertakes any analysis of other cases. 
of an evil. There is something far more ethical at work here, quite mdependent of the innocence of the perpetrator. Railroads injuring people, cedar trees destroying apple orchards, gravel pits hurtimg children are evils; property owners forestalling construction of an airport or gold mines forestalling the shift of men and inachines to other higher priority production are not evils. ${ }^{250}$ Most would sense it. Whether fully rationalized or not, we may be confronting in this rhetorical device a positive force, which, so long as consensus supports the characterization, is a reasonably accurate indicator of when we expect our institutions of governance to engage in the larceny we otherwise abhor. If so, it is an indicator the courts cannot ignore. And as such an indicator, it is of considerable moinent to our subject.

Even now, the argument that foreign ownership of Ainerican resources is an "evil to be eradicated" is inaking its ominous way in the land. Foreign owners, it is said, pose a threat to our economic system (by a tolerance for their own monopoly exactions and a penchant for financial inanipulation). They are a threat to our workers' welfare (displaying a greater disposition to locate production abroad), and to our moral values (harboring racial and religious biases we purport to spurn). They are, it is argued, a threat to our teclnology (exhibiting a propensity to keep research and development at hoine) and to our foreigu policy (exhibiting a greater responsiveness to the policies of their own governments). The point is not that we have come to view foreigu ownership in this way. It is that, should we do so with sufficient intensity, the courts are virtually certain to accord a large measure of flexibility to the government in fashioning a response. Divestiture of stock, transfers of assets at depreciated values, even direct expropriations with payinent in long-term bonds without any index to changing price levels, are only illustrative of measures which are likely to visit major financial losses upon foreign owners; however, they are measures which, more probably than not, will survive constitutional attack. And as the magnitude of the purported "evil" grows, so will the magnitude of the permissible deprivation. Perhaps it must be this way. But if so, it confronts the American courts with some singular choices in deciding how to deal with the comparable acts of foreign governments.

\section{B. The Consequences of Judging}

The central fact with which the American courts must deal seems rather clear. There is a potential divergence of major significance

250. In Eureka, Justice Burton did not attempt to meet Justice Harlan's contention that the absence of an "evil to be eradicated" further undercut the Government's claimed 
between constitutional precept and the traditional non-discriminatory, full, proinpt and adequate compensation standard of international law. The two will no doubt conform in many cases, but not in all.

There should, of course, be nothing surprising in all of this. The American government and the American people are not immune from the sensitivity that other people exhibit when purported legal standards threaten important public purposes. Nor can it be assumed that the courts will ignore this sensitivity - that they will enunciate constitutional standards without concern for their effects. And within limits, the nation's commitment to the rule of law demands precisely such sensitivity, since there can be no such rule unless the consensual nature of all law is clearly acknowledged. In other words, an American confiscatory act as momentous as those undertaken by many foreign governments could well be held exempt from the Constitution's just compensation requirement. If the judicial invalidation of such an act would also seriously contravene important American foreign and doinestic policies, it is to be expected that the courts will either find a way under established principles to validate the act or withdraw from the controversy altogether.

\section{Where Standards Diverge}

Against this background, the American courts cannot, it inust be urged, enforce traditional international norms against a foreign government in any case where the constitutional standard would differ. To do so would only invite an international law attack upon coinparable acts of the American government. The courts could no more sustain such an attack than they might sustain an attack under a like constitutional norm. The only way to preserve the traditional international standard in such a case, therefore, would be to abandon all pretense of judging like cases alike according to reasoned principles, or, alternatively, to abstain froin judging altogether. If unprepared to do either, they could only scuttle the traditional international norm and search for an international consensus sufficient to support a rule which conforms to the Constitution. For present purposes it is assumed that such a search is a reasonable alternative; Justice Harlan's skepticisin of the traditional law supports the assuinption, and Justice Powell's exhortation is an invitation to undertake the search. It is the consequences of doing so that are of immediate interest.

exemption from the just compensation requirement. 357 U.S. at 183-84 (Harlan, J., dissenting). 
Foremost among these consequences is the devastating effect which the espousal of such a rule would have on the prospects for a favorable diplomatic settlement of international imvestment disputes generally. Whether, in any case, the foreign government's action would be judged valid or not by an American court acting under an einergent international standard is beside the point. In any case involving a significant deprivation, American interests and international econounic intercourse will have suffered, and both justice to those injured and the cause of good order in transnational affairs demand as broad a settlement as possible. This is the province of diplomacy. If in the past the diplomats have been inept or insufficiently aggressive, that is for Congress and the President to correct. For the courts, the fundamental necessity is to preserve the credibility of the traditional non-discriminatory, full, prompt and adequate compensation standard of international law. That standard can and has played a vital role in the settlement of such disputes-so much so that one must attribute to the Legal Adviser a willingness to see Sabbatino overturned only upon the assumption that the courts would uphold the traditional norm. Otherwise, his suggestion was entirely out of place.

The point is, at bottoin, a matter of legal perspective. If it be recognized that the establishment of a norm of international law need not be committed to judicial authority, but to diplomacy as the appropriate remedial institution within the larger framework of the international legal system, judicial abstention ${ }^{251}$ can easily be seen as neces-

251. The ambit of this suggested abstention must be clarified. It is only intended to mean that the courts should abstain from judgment on the merits, and not to imply that they should abstain from all exercise of the judicial power. In fact, cases will arise where, having abstained on the merits, they must, under act of state, affirmatively enforce the foreign state act as the rule of decision in the case. Act of state can, in other words, import its own conflicts of law rule, precisely as, in the political question cases, the courts not infrequently .enforce the political departments' decision as the controlling rule of decision. Sce notes 128,146 supra.

As noted, there is no anomaly in the political question cases at all. Subject to a possible exception where the legitimating function of the Supreme Court is a matter of concern, see Korematsu v. United States, 323 U.S. 214, $245-56$ (1944); (Jackson, J., dissenting); A. Bickel, The Least Dangerous Branch 187-88 (1962), it is the contrary posture that would present the anomaly. Failure to enforce the political departments' decisions could undermine the very decision whose integrity made abstention necessary in the first instance. In Foster \& Elam v. Neilson, 27 U.S. (2 Pet.) 257 (1829), Chief Justice Marshall makes the point explicit by discussing a hypothetical case in which the parties were reversed. Id. at 309. In Williams v. Suffolk Ins. Co., 38 U.S. (13 Pet.) 415 (1839), it may have been true, as Dickinson has suggested, that the Court could have determined the plaintiff's right to recovery upon an examination of the de facto situation. Dickinson, supra note 130, at 456. Yet given the Court's assumption that the 
sary to the progress of law among nations. Viewed from this perspective, the consensus necessary to sustain a rule of customary international law need not be composed of decisions made by courts, which

was not possible, to have denied plaintiff his relief would have impaired the integrity of the very political department decision that it was constitutionally bound to preserve.

The parallel between act of state and political question, however, is not complete. As pointed out in note 128 supra, the policies of the American government that are being protected cannot supply the controlling rule of decision in the act of state case. The question, therefore, is whether the foreign state act can do so. Here cases like United States v. Palmer, 16 U.S. (3 Wheat.) 610 (1818), are instructive. In that case, indictments brought by federal authorities against defendants for highseas piracy against a Spanish vessel were dismissed. The reason was that the United States had recognized the existence of a civil war between Spain and the colony under whose authority defendants claimed to act and had adopted a policy of neutrality toward the conflict. To judge the defendants guilty (under United States statutes) would be, the Court said, to decide "that the war prosecuted by one of the parties was unlawful." It would "arrange the nation . . . against that party," in a fashion that would "transcend the limits proscribed to the judicial department." Id. at 634; accord, The Santissima Trinidad, 20 U.S. (7 Wheat.) 283, 337 (1822). Thus, contrasted with cases like Nielson and Suffolk, the political question in Palmer was not in the first instance the substantive legal issue raised by the pleadings. Defendants' alleged violation of the piracy statutes posed a political question only derivatively as a result of the prior conclusion that because a court, being independent, might arrive at a judgment of guilt, the act of judging itself posed an unacceptable threat to the controlling policy of neutrality. This is the exact parallel to act of state; consideration of the issue of the legality of the foreign state act is proscribed derivatively, because of the dangers an adjudication might pose to policy.

Thus, if judging a foreign state act to be invalid poses a proscribed threat to policy, and if a denial of controlling effect to that act would pose no less a threat, then under Nielson, and Suffolk with the Palmer variant, the judicial power must be affirmatively exercised when necessary to give that act controlling effect. Act of state imports its own conflicts of law rule. Certainly, a denial of controlling effect to a foreign state act will generally pose no smaller threat to policy than a judgment invalidating that act. Otherwise one must believe that a foreign government will act contrary to American interests-disrupt policy-if its laws are declared invalid, but not if its laws are merely denied the effect of valid laws; that it will defend the substantive legality of what it has done while confessing the lack of jurisdictional authority to do it. If, arguendo, a situation might arise where only the act of judging - not the denial of controlling effect - poses a threat to policy, that is for the political departments alone to determine.

Where a judgment of validity poses the proscribed threat to policy the issue becomes more intricate. A refusal to judge on the merits will largely secure against the adverse effects already considered under the Sardino formula. Likewise, such refusal will largely secure against the dangers of an adjudication to a negotiated settlement discussed here. Yet this latter concern may also necessitate affirmatively enforcing the foreign government's title to property. There is also a concern for the rights of other claimants in the Citibank situation. Thus, the use or non-use of the judicial power to enforce the foreign state act would appear to depend upon the position of the parties in the case. If the foreign government, or its successor in interest, is plaintiff in an action for the recovery of particular property, acceptance of that government's acts as the controlling rule of decision in the case would seem necessary in order to avoid prejudicing a negotiated settlement or to secure the larger community of American claimants in their rights. That uninformed observers may assign to the Court's action an implied validation of the foreign government's act would not seem a sufficient reason to bar such a judgment. 
may be concerned for their own integrity. Rather, it may be found in the standards deemed sufficient by political authorities to trigger an obligation to enter upon serious negotiations for the redress of grievances. And from this perspective, if it is this process of claim and counterclaim that promises to be the more adequate mode for the settlement of international disputes, national courts have a positive responsibility not to undermine that rule which lends to the process the maximum possibilities for action.

By this latter standard, it cannot be doubted that a strictly interpreted non-discriminatory, full, prompt, and adequate compensation standard is to be preferred. Without question it embraces, within its implied claim of a right to redress, the widest variety of confiscatory actions; few, if any, exhibiting some element of deprivation can escape. Claiming venerable antecedents and supported by a considerable rhetorical (if not behavioral) consensus, it remains an invaluable postulate of the international legal system. But it can only remain so if the courts of the United States refuse to intrude upon any controversy where they might be required to undermine the credibility of that norm. To ignore this, to assume an inevitable dependence of law upon judicial action, reflects a careless disregard of international law. In short, it is the dependence of international law upon the act of state doctrine that reveals the independent "underpinnings" of the doctrineunderpinnings rooted in the search for a more viable international order.

\section{Where Standards Conform}

At this point, it seems plain that a substantial part of the gap between Sabbatino and its precursors, on the one hand, and Justice Harlan's broad interdiction, on the other, has been closed. The courts must apply act of state im any case where the decision to judge raises a serious prospect of announcing a less rigorous standard than the traditional international law on the subject. The question remains, however, whether the courts should judge if they are confident of upholding that norm. Stated another way, can the courts decide whether or not to judge, without actually judging and thereby undermining the credibility of the more rigorous rule?

The context, it will be recalled, does not raise the prospect of granting an unfair preference to those claimants immediately before the

The Court would not, in fact, have validated the foreign act. If the foreign government is defendant, then the need to avoid disrupting a negotiation or to protect other claimants' rights would appear to render total abstention the better course. 
court. Moreover, the Supreme Court is even now agreed that, where the Executive is silent, a judicially self-imposed rule of abstention is appropriate if the unrepresented interests are in fact the larger community of Americans to be affected by an adjudication. But this is a matter which could readily be determined on a case-by-case basis. Likewise, if judgment involving a minor foreign act would embarrass wider American interests, this too would seem a inatter appropriate for case-by-case decision, with the Executive giving guidance. The only question is whether the integrity of the traditional international norm can be preserved if the courts proceed to differentiate case-by-case between those instances where they can confidently uphold that norm and those where to judge at all would be to impair its credibility. In other words, must the whole subject be governed by a blanket interdiction?

Unfortunately, to acknowledge that the American courts might judge in cases where an adjudication would not undermine traditional norms may be to do exactly that. Even were the courts to hold firmly against attempting to draw fine and discriminating lines, relyimg solely upon the broad indicia used here to illustrate the potential divergence between constitutional and international precept, the danger would remain. The very act of deciding whether or not to judge would be an acknowledgement of the existence of the divergence. Indeed, there is in Justice Harlan's opinion an imtrigning undercurrent which suggests his concern with this problem. His expressions of skepticism regarding the traditional standard hardly served to strengthen that standard, as Justice White was quick to point out. Given, however, that he was writing only a few years after his vigorous dissent in Eureka, one can read this expression as an elliptical way of explaining the problem so as to mimimize the damage he sought to avoid-a subtle reminder that any access to the courts might destroy the traditional norm altogether. Were the Supreme Court to unleash all the American courts to decide the issue on a case-by-case basis, the destruction would be virtually certain.

Cases such as Holzer ${ }^{252}$ and Bernstein, ${ }^{253}$ involving the Nazi racial decrees, illustrate the point nicely. Those acts were blatantly offensive to fundamental American conceptions of justice. To adjudicate, the courts would not have had to draw any fine line based upon the largeness

252. Holzer v. Deutsche Reichsbahn-Gesellschaft, 277 N.Y. 474,14 N.E.2d 798 (1938). See note 189 supra.

253. Bernstein v. Van Heyghen Frères S.A., 163 F.2d 246 (2d Cir.), cert. denied, 332 U.S. 772 (1947). See notes 189 and 201 supra. 
of the German government's purposes or the degree of deprivation. Arguably, in other words, they should have simply decided the cases, explaining that there was an exception to the act of state doctrine where the purpose of the foreign act, not its confiscatory character, was patently offensive to basic principles of American and international justice. But then what of a case charging that a foreign act discriminated against Americans or illegally retaliated against American governmental actions? Such acts may not, as Sardino pointedly illustrates, offend American constitutional precepts. By refusing to create an exception to the act of state doctrine in these latter instances, while doing so in a Bernstein situation, the American courts would be pointedly announcing that any State Department claim for redress on the grounds of discrimination or retaliation may be without foundation in American justice. ${ }^{254}$

In sum, the invitation to judge cannot be accepted or rejected without acknowledging, in one way or another, the existence of a standard which would destroy the credibility of executive claims under a strict view of the traditional law. If this is so, to accept an invitation to judge, because justice in a particular case favors an adjudication, is to view the question of justice from an inpermissibly narrow perspective, a perspective which ignores the problem of justice in all future cases.

One can only hope, in other words, that the Supreme Court will eventually see the wisdoin of reaffirming that the courts of the nation, state and federal alike, are not to judge whether an expropriatory decree of a recognized foreign government is valid under customary international law in cases where the property in issue was located within that government's territory. One may even hope that it will extend this holding to all other forms of confiscatory action against which the Executive might legitimately tender a claim of international illegality under traditional norms. ${ }^{255}$

On the other hand, in this context, removed from the very particular circumstances of the Cuban cases, it would not appear that act of state signals a non-justiciable political question. Rather, it appears to rest upon constitutional underpinnings alone. If so, the courts would seem bound to obey any congressional directive to adjudicate, doing so, however, only in accord with such international standards as imight con-

254. See note 257 infra for a discussion of the "Bernstein exception."

255. See, e.g., French v. Banco Nacional de Cuba, 23 N.Y.2d 46, 242 N.E.2d 704, 295 N.Y.S.2d 433 (1968). 
form to constitutional precept. ${ }^{256}$ In like fashion, the doctrine might in this context be set aside by executive intervention. But im no event could it be set aside unless the Executive were to make clear its willingness to abide by whatever decision was forthcoming, including a decision that the traditional international legal standard did not conform to the American view of that law as applicable to the case. ${ }^{257}$

\section{The Territorial Limitation}

Thus far, the analysis has worked largely within the bounds of the territorial qualification of Justice Harlan's broad rule. The analysis of Dunhill, however, has already suggested the possibitity of deviations from that limit. The basic thesis of this Part brings the issue to the fore.

Generally, because the realities of national power, national concerns and national expectations result in a differentiation between people and objects within a nation's territory and those without, it can be expected that a judicial denial of extraterritorial effect to a foreign state act will not precipitate those direct embarrassments to policy which would otherwise compel its recognition. Exceptions will, of course, have to be acknowledged, as the Litvinov Assignments cases pointedly illustrate. ${ }^{258}$ But these instances, no less than such cases as Dunhill or cases in which an adjudication would intrude the courts into the political realm, as in our Cuban variant, must be regarded as rare prospects at best. The central problem lies instead in the fact that even

256. We leave aside the question of how the courts should respond should Congress attempt to lay down a contrary international rule under its power "To define and punish Piracies and Felonies committed on the high Seas, and Offences against the Law of Nations," U.S. CoNST. art. I, $\S 8, \mathrm{cl} .10$. It is to be noted that no such attempt was made in the Hickenlooper/Sabbatino Amendment.

257. This is the basis for a distinction between the very narrow Bernstein setting and the more general case, especially where the measure of compensation is the principal defect in the foreign state act. In both cases the court can announce that there is indeed a "Bernstein exception" to the doctrine. See note 201 supra. In the Bernstein setting the Executive need give no assurances regarding the standard to be employed, confident that the foreign act will be declared invalid. The court, without more, can declare the law patently offensive to international justice without engaging any of the difficult questions discussed above. In all other cases, if the Executive is silent-which it must be in order to preserve the credibility of the traditional norm-the court will be compelled either to question the Executive or, confident of the latter's distaste for anything but the traditional norm, to decide whether it will be able to judge according to that norm, inviting precisely the dangers against which act of state is designed to secure.

258. United States v. Pink, 315 U.S. 203 (1943); United States v. Belmont, 301 U.S. 324 (1937). Note especially Justice Stone's dissent in Pink, his concurring opinion in Belmont, and Justice Frankfurter's concurrence in Pink. 
in an extraterritorial case, the courts must maintain their own imtegrity without announcing a standard of judginent which effectively contradicts the traditional international norms on the subject.

The mere fact that property, by some appropriate choice of law test, has its situs in the United States does not foreclose all claims that the control and disposition of the property should be determined as a foreign state has decreed, wholly without regard to the act of state doctrine. Such a claim may be predicated upon the normal rule of prescriptive jurisdiction, as in Republic of Iraq v. First National City Bank. $^{259}$ It may rest upon the normal right of a firm, or its managers and owners, to firm property, as in Dunhill and many of the Soviet cases. $^{200}$ It may rest upon a clain of excuse for non-performance of a contract by reason of the foreign government's action, even though the proper law of performance may be the American law. ${ }^{261}$ Other examples undoubtedly exist. But whatever the predicate, the American courts will not infrequently find the claim to be a compelling one, not to be demied unless some reason in their own national policies requires it.

Typically, this has led the courts to inquire whether the foreign act offends what is called American public policy, a concept almost invariably given a highly normative content ${ }^{202}$ and a concept which, were it ever interpreted in a scrupulously evenhanded fashion, could certainly lead to the enunciation of standards no less destructive of executive credibility than like pronouncements regarding international law. Or, to make the poimt obvious, assuming interpretive integrity, act of state would seem to be applicable to claims of extraterritorial prescriptive right no less than to purely territorial assertions, unless the courts can find some other, non-normative basis in policy for the refusal to recognize such claims.

It is possible, of course, that public policy could be interpreted to exclude any normative implications. It might be defined as a straight-

259. 253 F.2d 47 (2d Cir. 1965) (attempt by government of Iraq to expropriate funds of its deposed monarch held in a New York bank).

260. See, e.g., Tabacalera Severiano Jorge, S.A. v. Standard Cigar Co., 392 F.2d 716 (5th Cir. 1968); Zwack v. Kraus Bros., 237 F.2d 255 (2d Cir. 1956); Vladikavkazsky Ry. v. New York Trust Co., 263 N.Y. 369, 189 N.E. 456 (1934); Petrogradsky Mejdunarodny Kommerchesky Bank v. National City Bank, 253 N.Y. 23, 170 N.E. 479 (1930).

261. See the discussion of the Cuban Insurance Cases in text accompanying note 89 supra.

262. See, e.g., Republic of Iraq v. First Nat'l City Bank, 353 F.2d 47 (2d Cir. 1965); Loucks v. Standard Oil Co., 224 N.Y. 99, 111, 120 N.E. 198, 202 (1918) (Cardozo, J.). 
forward assertion of self-interest-a simple refusal to aid a foreign government which has injured Americans or other aliens-and, as such, an assertion devoid of any suggestion that the foreign act is immoral, unjust, or illegal, or that the United States would never behave in kind. This, however, is not what is usually meant by the phrase, and until the courts are prepared to posit such a definition, sone other policy must be found.

Here the traditional refusal of the courts, as Justice Marshall phrased it, to "execute the penal laws" of another state, ${ }^{263}$ would seem to supply an answer. It is a rule firmly rooted in Anglo-Anierican legal history. Some of its earliest applications involved foreign confiscatory acts. ${ }^{264}$ Its origins can be traced to the special nature of the English common law jury, and its survival to notions of sovereignty and other more praginatic concerns. ${ }^{265}$ In its more orthodox expressions, the rule has been extended beyond traditional common law crimes to foreign revenue laws, to the whole realin of foreign public law and to such noncriminal penal cases (to use Leflar's apt phrase) ${ }^{266}$ as actions on official bonds and for wrongful death, punitive damages and family support. In its orthodox use, the rule was said to bar not only the affirmative enforcement of a penal clain (i.e., its execution) but all forms of recognition. ${ }^{267}$

It is, of course, true that particularly in the United States this orthodoxy has come under severe and well-taken criticism. The rule, at least in the area of non-criminal penal cases, has been increasingly abandoned. When the Court in Huntington v. Attrill ${ }^{268}$ required that full faith and credit be given those sister state judginents that were intended only to "afford a private remedy," although penal in nature, and not intended to "punish an offense agamst the public justice of the state," it supplied a definition helpful in circumscribing the older orthodoxy. Nevertheless, it would still appear axionnatic that the American courts will not entertain a foreign governinent's claim to money or property prescribed as a penalty for the commission of a crime under foreign

263. The Antelope, 23 U.S. (10 Wheat.) 66, 123 (1825).

264. See Wolff v. Oxholm, 105 Eng. Rep. 1177 (K.B. 1817); Folliott v. Ogden, 126 Eng. Rep. 75 (C.P. 1789), aff'd, 100 Eng. Rep. 825 (K.B. 1790), aff'd, 2 Eng. Rep. 75 (H.L. 1792).

265. On the impact of the English jury see Sack, Conflicts of Law in the History of English Law, in The LAw: A Century of Progress (1937). For a more specific treatment of the penal law rule, see Katzenbach, supra note 61, at 1140-47.

266. See Leflar, Extrastate Enforcement of Penal and Governmental Claims, 46 HARV. L. REv. 193, 202 (1932).

267. See A. Dicey \& J. Morris, The Conflict of LAws 77-78 (9th ed. 1973).

268. 146 U.S. 657 (1892). 
law. ${ }^{269}$ Nor would they be likely to recognize a foreign judgment for such a penalty even if the proceedings otherwise met all the requisites of jurisdiction, fairness and conformity to public policy. ${ }^{270}$ It is also doubtful that they would permit a foreign criminal conviction to be pleaded in a subsequent civil action as either prima facie or conclusive proof of the facts adjudged, even if prepared to grant such collateral estoppel effect to their own or sister state convictions. It should not be too difficult to fit a foreign confiscatory statute or regulation into this pattern, where the deprivation is for the benefit of the foreign government and purports to be in furtherance of some public purpose.

Such an application is readily distinguishable from the noncriminal penal cases which have engendered the bulk of the criticism of the rule. Nor would such an application necessitate extending the rule to the whole of a foreign government's public law, but only to such laws which as a matter of fact deprive aliens of established property rights. Whether or not there is any contimuing vitality to the traditional ideas of sovereiguty which sustained the rule in the past, it finds ample justification as a statement of policy for our subject. It is historical and normatively neutral. It would permit the courts to refuse aid to a foreign government that has injured private American interests without having to coinpromise the credibility of American diplomacy by the issuance of normative assessments conforming to a more objective view of American justice. Being normatively neutral and confined to attempted extraterritorial deprivations, such a denial of aid is not likely to be so offensive to a foreign government as to endanger the wider interests of the nation. And given the larger purpose of preserving the credibility of the diplonnatic nechanisn, the mere fact that a particular foreign act inay comport with American public policy is no reason to recognize that act. If America's political interests require recognition, then, as in Pink and Belmont, act of state should be applied.

Thus, for example, in Republic of Iraq, when Iraq claimed King Faisal's New York bank accounts after the King was killed in a revolution, Judge Friendly, rather than searching in the constitutional prohibition against bills of attainder and elsewliere for the American standard of justice, might simply have refused to recognize the government's claim as "penal" and proceeded to apply the normal rule, under the law of New York (the situs), that assets belonging to an individual at death pass to his estate. In cases involving a claim to the assets of an expropriated firm, the court, announcing its refusal to recognize the

269. Restatement (SeCOND) of the Conflict of Laws $\$ 89$ (1971).

270. Id. $\S 120$, comment $d$ at 345-46. 
take-over as penal, would simply proceed to apply the normal rules under which the former shareholders and directors of a company are entitled to the possession of firm assets located $\mathrm{m}$ this country whenever the divestiture of their ownership is not recognized by the American courts. ${ }^{271}$ In a contract case, the foreign state act would, on like grounds, be rejected as a recognized excuse for non-performance and the contract enforced according to its "proper law."

Obviously, the penal law rule cannot be used to circumvent the act of state doctrine as Justice Harlan defined its ambit (i.e., in the territorial case). If an American court determines, accordimg to its own conflicts of law rules, that a foreign act is territorial, it would be anomalous to deny that law controlling effect. Only if the latter offends international law or some normative postulate of American law imight it do so. Yet it is precisely such normative assessments that act of state forbids. For a court to deny recognition on such non-normative bases as the penal law rule would still leave open the question of who wins (i.e., is the government or the private claimant entitled to the property, or the latter to damages _ —an issue to be decided according to some law. ${ }^{272}$ Unlike the extraterritorial case where its own law can be applied, or the case where some other normative standard may serve to supply a rule of decision (e.g., Citibank's claim in "international tort"), the court, foreclosed from all normative assessments, is forced to concede exclusive prescriptive rights to the foreign government. To arbitrarily intrude its own substantive law, or the pre-existing rule under foreign law, would, in addition to implicitly invalidating the later act of that government, be a total denial of the very legislative authority which it has already admitted and which it claims for itself. And to issue such a denial without any normative bases, and only because it is displeased with the way the foreign government has exercised its preclusive rights, would be to undermine the whole structure of international order. If there is displeasure, diplomacy is the recourse.

\section{CONCLUSION}

In the final analysis there remains a certain larger choice. Undoubtedly the American courts could "get away" with continuing to

271. See Zwack v. Kraus Bros., 237 F.2d 255 (2d Cir. 1956); Vladikavkazsky Ry. v. New York Trust Co., 263 N.Y. 369, 189 N.E. 456 (1934).

272. This supplies a critical operational distinction between cases involving foreign expropriatory acts and those involving foreign revenue laws. The latter need no further "rule of decision" to settle the controversy, raising the distinct possibility that act of state need not be extended to foreign revenue laws except perhaps in very unusual circuunstances. 
moralize against foreign governments while indulging their own. The State Department could certainly sort out the statements useful to it. Foreign governments will continue to take property and settle disputes over the takimg as their interests, and not American judicial pronouncements, dictate. So long as the American courts hold fast to traditional norms in dealing with the acts of those governments, any perceived inconsistency in dealing with the acts of the American government will be, at best, a mere peccadillo in a process where economic and political power counts most. And out of this, a few Americans may recover some part of that which they would otherwise have lost.

On the other hand, some of the strength, even the majesty, of American law would surely be lost if it were continuously washed in such cynical acids. In the longer view we would all be diminished. It is not inappropriate, therefore, to urge that the Court, still laboring to see where it should go in the long progress of American law, pause to celebrate Justice Harlan's work: the larger and more objective view, the ethical acuity, that could offer so plain an affirmation of principle at the very height of political excitement against its immediate beneficiaries. 